\title{
Language and Participation
}

\author{
Cristina M. Rodríguez†
}

In this piece, I tackle a current subject of popular controversywhether growing multilingualism in the United States imperils the future of American democracy. I offer a positive theory, centered on the value of democratic participation, of how a society like the United States should approach the multilingualism of its population. I conclude that embracing bilingualism in individuals and multilingualism in society is more likely to make linguistic pluralism socially functional and to sustain the vitality of public and social institutions than demanding public monolingualism. I begin by demonstrating that current approaches to language diversity in constitutional democracies, including our own, are largely remedial in nature. They focus either on ensuring the survival of particular minority groups historically present and marginalized in a given nation-state, or on helping immigrants overcome language barriers as they assimilate into the dominant language of the society in question. On its own, this remedial conception cannot ensure that linguistic diversity complements, rather than undermines, democratic institutions, because it does not account for the variety of linguistic interests present in a multiethnic society. I then address this limitation by offering an alternative, participatory theory of language difference. I base my conception of participation on principles of decentralized decisionmaking. This focus requires considering how to expand the individual's associative options and improve access to the midlevel social institutions where we live out most of our lives, such as the

Copyright $\bigcirc 2006$ California Law Review, Inc. Califomia Law Review, Inc. (CLR) is a Califomia nonprofit corporation. CLR and the authors are solely responsible for the content of their publications.

$\dagger$ Assistant Professor of Law, N.Y.U. School of Law. For their particularly helpful comments on this Article, I would like to thank Bill Eskridge, Benedict Kingsbury, Daryl Levinson, Will Kymlicka, Jerry López, Deborah Malamud, Martha Minow, Rachel Moran, Liam Murphy, Alan Patten, Denise Réaume, participants at the 2004 N.Y.U. Summer Faculty Workshop, and participants in the Multiculturalism Working Group at the 2005 IVR Legal and Social Philosophy Conference in Granada, Spain. For their insights on early versions of this piece, I would like to thank Bruce Ackerman, Jack Balkin, Jules Coleman, Owen Fiss, Harold Koh, Daniel Markovits, Reva Siegel, Kenji Yoshino, and participants in the faculty workshops at Boalt Hall, Duke, Georgetown, Harvard, N.Y.U., Stanford, UCLA, University of Chicago, University of Michigan, University of Minnesota, University of Virginia, Vanderbilt, and Yale. I am most grateful for the excellent research assistance of Benjamin Fishman and Lisa Ross, for the tremendous library support of Liz Evans and Mirela Roznovsci, and for the outstanding editorial contributions of Shelley Cavalieri and the editors at the California Law Review. 
workplace and the public schools. In accommodating speakers of multiple languages in a given institution, we should focus on promoting social investment by individuals and groups, as well as preserving individual control over matters of deeply personal concern, rather than on the survival of particular languages or cultures. In developing this framework, I draw from the experiences of other multilingual societies and legal systems, but I present the United States as a case study to explain what a participatory approach would look like in practice. I focus on the major sites of language conflict in the United States- the political arena, the debate over official English, the workplace, and the public schools-and argue that a multilingual understanding of these sites and the legal rules that structure them best promotes participation.

\section{INTRODUCTION}

When speakers of different languages inhabit the same space, friction often results. In January 2005, for example, a child-court judge in Tennessee made headlines for ordering a number of non-English speaking women involved in custody or neglect disputes to take English language classes for "the good of their children." In at least one case, the court apparently threatened that failure to comply within six months would result in the termination of parental rights. ${ }^{2}$ In July, upon hearing a coach instruct a fourteen-year-old pitcher, in Spanish, to pick off a runner at second base, a Little League umpire in Massachusetts ruled that only English could be spoken for the remainder of the game. ${ }^{3}$ Though Little League officials responded to the subsequent protest by suggesting that the umpire had no malicious intent, the League nonetheless suspended the official for the remainder of the tournament. ${ }^{4}$ In October, a co-op on the Lower East Side of Manhattan erupted in debate over the building's policy requiring all porters to speak only English while on the job. ${ }^{5}$ Upon learning of the policy, the tenants lit up the neighborhood's online message board with condemnations, but the management corporation defended its policy on the grounds that it furthered public safety and communication. ${ }^{6}$ And, in December, the principal of a Kansas City public high school sent a sixteen year-old student home for asking a classmate, in Spanish, to borrow a dollar. ${ }^{7}$ In the wake of the controversy that ensued, the school district rescinded the

1. Natalia Mielczarek, Judge Tells Moms in Custody Cases to Learn English, TenNessean, Jan. 29, 2005, at I A, available at http://www.tennessean.com/local/archives/05/01/64800164.shtml.

2. See id.

3. See Associated Press, No More Games for Umpire Who Banned Spanish, July 29, 2005, http://sports.espn.go.com/sports/news/story?id=21 19529 .

4. See id.

5. See Richard Morgan, English Only, Por Favor, N.Y. Times, Oct. 9, 2005, § 14, at 5.

6. See id.

7. See T.R. Reid, Spanish at School Translates to Suspension, WASH. PosT, Dec. 9, 2005, at A3. 
suspension, but not before the school's principal had made clear that the student and others had been asked, prior to the incident, not to speak Spanish at school. ${ }^{8}$

Each of these episodes reflects ambivalence about the propriety of communicating through languages other than English. Since its colonial beginnings, the United States has been a multilingual society, but this linguistic diversity has long complicated our conceptions of American national identity. Rhetorical battles over linguistic identity are often fought at high levels of generality, through debates over whether English--the dominant language - should become the official language. But as these various episodes suggest, the debate also takes place on a local and everyday basis in the commercial, communal, and familial spaces of this country.

In recent years, language diversity has become a particularly salient and controversial feature of American demography, because dramatic rates of immigration are reshaping our social, political, and aesthetic environments. ${ }^{9}$ The foreign-born and their children now constitute approximately twenty percent of the U.S. population. ${ }^{10}$ These groups are "concentrated in a number of large states such as California, Florida, New York, Texas, and lllinois, magnifying the regional impacts of immigration." City-a city of eight million people - is now home to almost three million foreign-born residents. ${ }^{12}$ Of that population, almost $43 \%$ arrived in the United States in the past ten years, and $46 \%$ of that population speaks a language other than English at home. ${ }^{13}$ In other, smaller cities, such as San

8. See id.

9. As a recent study of immigration and assimilation points out, the 2000 Census documents this wave. See Richard Alba \& Victor Nee, Remaking the American Mainstream: Assimilation AND CONTEMPORARY IMmigration 9 (2003). According to the study,

[1mmigrants'] presence has been dramatically visible in Califomia, the nation's most populous state, where one in eight Americans resides. The state's robust population growth during the 1990s, almost 10 percent, was largely driven by the rapid increase in the Hispanic and Asian populations, which grew by 33 and 34 percent rcspectively. ... The profundity and rapidity of Califomia's demographic change are unlikely to be replicated on a large scale elsewhere in the United States in the near future; but in some other large states and metropolitan areas, nonwhites and Latinos have achieved a critical mass sufficient to exercise a strong, if not increasingly dominant, influence on regional devclopments."

Id. The 2000 Census also reveals that one in five U.S. residents speaks a language other than English. In addition, it projects that, by 2044, a majority will speak a language other than English, though not necessarily to the exclusion of English. James Crawford, National Association for Bilingual Education, Making Sense of Census 2000 (2005), http://www.nabc.org/research/demography.html; see also Hyon B. Shin \& Rosalind Bruno, Language Use and English-Speaking Ability: 2000; Census 2000 Brief (2003), http://www.census.gov/prod/2003pubs/c2kbr-29.pdf (presenting language data from the 2000 U.S. Census).

10. ALBA \& NEE, supra note 9, at 8-9.

11. Id. at 9 .

12. New York City Department of Planning, The Newest New Yorkers 2000: IMMIGRANT NEW YORK IN THE NEW MILlENNIUM xi (2004) (executive summary available at http://www.nyc.gov/planning/nny).

13. Id. at 1 . 
Antonio, Texas, the Latino population has climbed to sixty percent-a trend due, in large part, to recent immigration from Mexico and Central America. ${ }^{14}$

Whereas the economic consequences of this immigration are often discussed ${ }^{15}$ the cultural consequences of these changing demographics remain undertheorized. But the cultural effects of immigration are palpable and must be understood clearly. One of the standard responses to the immigrant influx, repeated at various stages of American history, recently has found high-profile expression in Samuel Huntington's plea for the soul of America, in which he warns, "There is no Americano dream. There is only the American dream created by an Anglo-Protestant society. Mexican Americans will share in that dream and in that society only if they dream in English." 16 According to Huntington, American democracy now faces the possibility of its own unraveling, brought on by the failure of an unprecedented number of recent immigrants, mostly from Latin America, to assimilate linguistically and culturally into an English-speaking mainstream. Whatever one thinks of Huntington's dire predictions, he broaches an important question-is there a relationship between linguistic diversity and the future of our democracy?

The mainstream, liberal response to Huntington's argument insists that linguistic assimilation continues apace-that the grandchildren of Latin American immigrants "could not dream in Spanish even if they wanted to." ${ }^{17}$ Despite the fact that this retort has strong sociological data on its side, ${ }^{18}$ it elides an important point, and the account of language diversity

14. See Simon Romero, Texas Paper Bets on Español, Not Assimilation, N.Y. Times, Jan. 31, 2005 , at C1.

15. See, e.g., George Borjas, Richard Freeman, \& Lawrence Katz, How Much Do Immigration and Trade Affect Labor Market Outcomes?, 1 Brookings PAPERS ON ECONOMIC ACtivity 1, 62-63 (1997); The New americans: Economic, Demographic, and Fiscal Effects of lmmigration (James Smith \& Barry Edmonston eds., 1997).

16. Samuel P. Huntington, The Hispanic Challenge, Foreign Polıcy, Mar.-Apr. 2004, at 30, 45; see also SAmuel P. Huntington, WHO ARE WE?: THE CHALlENGES TO AMERICA'S NATIONAL IDENTITY 18-19 (2004) (discussing the unique impact of Spanish-speaking immigrants in the context of discussing the crisis of identity facing the United States in this century).

17. Lawrence H. Fuchs, Mr. Huntington's Nightmare, American Prospect, Aug. 2004, at 70, 71 (reviewing Samuel P. Huntington, Who ARE WE?: THE Challenges to AMERiCA's National IDENTITY (2004)); see also Andrew Hacker, Patriot Games, N.Y. Rev. of Books, June 24, 2004, at 29 ("As [critic] Louis Menand wrote... [Huntington] doesn't seem aware of the recent finding by the sociologists Richard Alba and Victor Nee that in 1990 'more than 95 percent of Mexican-Americans between twenty-five and forty who were born in the U.S. could speak English well."').

18. All studies of the current immigration demonstrate that "linguistic assimilation in the form of English acquisition is a quasi-universal pattem." ALBA \& NEE, supra note 9, at 220-21; see also id. at 220 ("[S]ome proficiency in English generally is apparent among immigrants who have resided in the United States for more than a few years, and English proficiency attains a high level among their U.S.born children. Even in the largest enclave economies...U.S.-born generations are, to an overwhelming degree, fluent in English."). Census data and social science studies also reveal that imrnigrants and their descendants acquire English ability in the first generation and English fluency in the second. See Richard Alba, Lewis Mumford CTR. FOr Comparative Urban \& Regional 
it offers is incomplete. Even as the children and grandchildren of immigrants become native English speakers, the United States will remain, as it always has been, a multilingual society. Statistics documenting assimilation cannot explain away the tension Huntington has identified, for two reasons. First, at least with respect to immigrants from Latin America, bilingualism persists strongly in the second generation and even somewhat in the third. Whereas the classic three-generation trend toward English monolingualism describes most immigrant groups as a whole, ${ }^{19}$ some theorists hypothesize that English-Spanish bilingualism may prove an exception to this classic rule-a possibility that seems plausible in light of the sheer number of immigrants from Latin America, the proximity of their countries of origin, and their continued regional concentration. ${ }^{20}$

Second, and more universally, continued immigration will ensure the ongoing replenishment of immigrant communities - a phenomenon not characteristic of the experience of European immigrants in the twentieth century. ${ }^{21}$ This change in the nature of immigration means that multiple generations of Americans, possessing varying levels of facility with nonEnglish languages, will remaim present in the body politic, even as individual family lines assimilate linguistically. ${ }^{22}$ Speech communities comprised of non-English-speaking immigrants, their monolingual-in-English descendants, and a wide array of bilinguals in between will persist-a

Research, University at Albany, Language Assimilation Today: Bilingualism Persists More ThaN IN THE PASt, But ENGlish StILl Dominates (2004), http://mumford.albany.edu/ children/reports/language_assimilation/language_assimilation_brief.pdf; see also SHIN \& BRUNO, supra note 9 , at 2-3 (noting that in the 2000 Census, $55 \%$ of people who spoke a language other than English at home reported speaking English "very well," meaning that, when combined with those who spoke only English at home, $92 \%$ of the population over five years of age had no difficulty speaking English).

19. As Alba and Nee explain, this paradigm of language shift, according to which a transition to English monolingualism occurs over the course of three generations, was first demonstrated by sociolinguists Joshua Fishman and Calvin Veltman. This pattern, almost without exception, held for earlier, predominantly European immigrant groups. ALBA \& NEE, supra note 9, at 219. "Schematically," they write, "the process of Anglicization occurs in the following way. Some individuals of the immigrant generation learn English, though they generally prefer their native language, especially at home. Thus, their children usually grow up as bilinguals, but many of them prefer English.... Members of the second generation generally speak English at home when establishing their own households and rearing children. Consequently, by the third generation, the prevalent pattern is English monolingualism, and knowledge of the mother tongue for most ethnics is fragmentary at best." Id.

20. Id. at 220 ("Spanish [may be] unique among immigrant languages in its ability to resist the hegemony of English.").

21. See Mary C. Waters \& Tomás R. Jiménez, Assessing Immigrant Assimilation: New Empirical and Theoretical Challenges, 31 ANN. REv. Sociol. 105, 107 (2005) (arguing that the conception of generation inust he rethought, given the "ongoing replenishment of new immigrants that is likely to be a defining characteristic of American immigration for years to come").

22. See Cristina M. Rodriguez, Accommodating Linguistic Difference: Toward a Comprehensive Theory of Language Rights in the United States, 36 HARV. C.R.-C.L. L. REv. 133, 142-45 (2001). 
phenomenon I have called the mutability continuum of language. ${ }^{23}$ In fact, the 2000 Census predicted that, by 2044, a majority of people residing in the United States will speak a language other than English, though not necessarily to the exclusion of English. ${ }^{24}$ For the foreseeable future, bilingualism will remain a demographic characteristic that complicates our cultural, sociaI, and political interactions. ${ }^{25}$

In light of these observations, neither the Anglo-Protestant "ideal" nor the liberal version of the assimilation story can account for the modern reality of the United States as a truly multilingual society. The former yearns for a homogeneous national identity that bears little resemblance to demographic reality and that has never quite existed. The latter, while descriptively accurate, does not provide the necessary substantive account of how individual bilingualism and social multilingualism may be changing the character of our political and social institutions. The presence of speakers of languages other than English is reshaping important social settings, such as the workplace, the schools, and the countless different fora in which politics occur. To deal adequately with this inescapable demographic and Iinguistic reality, we need to understand the effects of language diversity on the dynamics in these institutions.

Despite an ever-present and increasingly pressing need for this type of thinking in the United States, our understanding of the relationship between linguistic diversity and democracy remains thin. We resort too often to general discussions of multiculturalism and assimilation to answer the challenges of multilingualism. ${ }^{26}$ Whereas that ongoing debate forms an important context for discussions of language rights and policy, the

23. See id,; see also AlBa \& NEE, supra note 9, at 229 ("For as far into the future as the eye can possibly see, then, the United States will be a polyglot society, displaying a robust linguistic pluralism. Large parts of the first and second generations, along with smaller parts of the third, will be bilingual, and their numbers will grow if immigration continues at its present clip."); Waters \& Jiménez, supra note 21 , at 120 (discussing how replenishment helps to "refresh" the ethnic identity of second- and third-generation Mexican Americans).

24. See supra note 9.

25. Scholars in various fields have noted this phenomenon. See, e.g., BiLingual Games: Some Literary Investigations (Doris Sommer ed, 2003); The Multilingual anthology of AMERICAN Literature (Marc Shell \& Wemer Sollors eds., 2002).

26. Huntington's emphasis on the linguistic dimension of assimilation, or the lack thereof, in Who Are We? offers a classic example of this tendency. See generally Huntington, Who ARE WE?, supra note 16. The language question, until recently, has been subsumed by political theorists within larger discussions of multiculturalism and its critics. See WILl Kymlicka, Multicultural Citizenship 45 (1995) (discussing minority language rights in the context of a broader discussion of collective rights); Language Rights and Political Theory 1-2 (Will Kymlicka \& Alan Patten eds., 2003) (discussing absence, until recently, of a free-standing normative theory of language rights); Alan Patten, Political Theory and Language Policy, 29 Pol. TheORY 691, 691-92 (2001) (noting that language conflict implicates many of the same values at stake in multiculturalism debates, such as "equality, recognition, freedom, identity, democracy, and cultural preservation," but that various features of language make it distinctive and therefore in need of separate treatment). 
language question must be confronted independently. ${ }^{27}$ In both an instrumental and affective sense, language serves as the fundamental medium of social interaction. At the same time, though certain languages may correlate with worldviews, they are not themselves values or practices. As a result, debates concerning the extent to which we should accommodate conflicting cultural values will not point to the best way to manage multilingualism.

In this Article, I reconceptualize the social significance of language difference by offering a positive theory of how a democratic society like the United States should approach the multilingualism of its population. Whereas existing models of language rights focus primarily on correcting injustices against particular minority groups, my central claim is that our legal and political framework for managing multilingualism should be built around the value of participation in public life. In the spirit of interpersonal engagement at the heart of language itself, the best model for the United States will strive to make linguistic pluralism, whatever its source, socially functional.

This approach makes a certain amount of intuitive sense. Because language serves as the medium for interaction among people, democratic societies naturally will be concerned that linguistic differences not stymie such interaction or prevent people from accessing important social and governmental resources. As I elaborate below, a number of legal systems acknowledge this interest in participation to some degree when addressing the interests of different cultural and linguistic groups. In international law circles, for example, advocates argue that minority interests should be framed in terms of the right to "effective participation."28

But existing models remain limited in their utility as points of comparison for an American project of language rights, for a few reasons. First, the participatory approach has not been fleshed out in any systematic way. The capaciousness of the term "participation" explains, in part, why a participatory account remains nascent and ambiguous. Participation can be understood to encompass a wide variety of activities, and it may mean different things in different national contexts.

Second, existing models, despite containing participatory aspirations, share a central preoccupation that necessarily limits the reach of these aspirations. The language rights discourse of scholars, activists, and lawmakers the world over focuses primarily on remedying the unequal status of

27. See Patten, supra note 26 , at 692 (discussing the features that make language distinctive, including the fact that "language is the medium in which most social interaction takes place," and "the fact that most people can speak only one or several languages").

28. See, e.g., Organization for Security and Co-operation in Europe, Copenhagen Declaration, June 29, 1990, art. 35 ("The participating States will respect the right of persons belonging to national minorities to effective participation in public affairs, including participation in the affairs relating to the protection and promotion of the identity of such minorities."). 
specific national minority groups, such as French-speaking Quebeckers and Catalans, and keeping the peace between groups with a history of conflict. ${ }^{29}$ Those who operate within this framework conceive of language rights as belonging to national minority groups in particular, and language policies in most societies have been targeted primarily at ensuring these groups' survival. This remedial conception of language rights is most clearly visible in the emergence of separate institutions or political arrangements for once oppressed or marginalized national minority groups, as has occurred in Canada or Spain.

But neither the focus on national minorities, nor the forms of accommodation that this focus has generated, fit well in the American context. For the United States, we require an account of multilingualism that moves beyond the limitations of existing models to address the linguistic pluralism created by the migration of peoples. This account must be based on something more than the standard rhetoric emphasizing that immigrant groups are not entitled to substantive recognition of their linguistic interests, apart from their right to access an English-speaking world.

The alternative account I offer in this Article refocuses our approach to multilingualism around a theory of participation and engages several key issues: (1) how linguistic diversity affects participation in social and political life; (2) how we should regulate multilingualism to promote participation in those spheres; and (3) whether we should emphasize monolingualism or multilingualism in our institutions to achieve these participatory ends. At first glance, it may seem obvious that participation, because it requires interaction, would be more effective and efficient if everyone used the same language. A viable participatory account, under this view, would emphasize monolingualism and policies that promote rapid linguistic assimilation. My ultimate conclusion, however, is that this initial, monolingual instinct cannot survive a second look into the nature of participation. In exploring the effects of multilingualism on the institutions with which I am concerned, I contend that bilingualism in individuals and multilingualism in society promote democratic values in those institutions. A multilingual conception of participation will better advance two important objectives of American democracy: social investment by minority language groups and personal control or autonomy over matters of deeply personal concern, including cultural destiny.

In developing my participatory account, I emphasize two important diniensions of participation that transform the counterintuitive into the selfevident. First, I focus on mid-level social institutions-workplaces, schools, and the scenes of everyday politics and government, or the arenas through which most citizens live their daily lives-rather than on national

29. See infra notes 34-54 and accompanying text (discussing efforts in Spain, Canada, and Latvia to raise the status of current and former national minority languages). 
political institutions. Second, 1 conceptualize participation as access to social institutions, not as conversation over issues of common concern. This approach deemphasizes the idea that all conversations of public concern must be mutually intelligible to all people at all times, recognizing instead that any given public debate will occur through simultaneous, overlapping conversations by multiple communities. This framework ultimately contemplates that particular languagcs may differ in their social status and may not be used to the same degree at all levels of civic society.

I aim primarily to provide a framework for thinking about language diversity in the United States, and I therefore elaborate the details of my theory using institutions and debates in the United States as examples, because I aim primarily to provide a framework for thinking about language diversity in the United States. I begin this Article, however, by exploring the ways in which other societies have dealt with their own language questions. Though language differences always have fueled intense conflict in societies around the world, ${ }^{30}$ examples of robustly multilingual, participatory democracies abound. These societies thrive because they make linguistic pluralism and popular self-government mutually reinforcing, as opposed to destructive of one another. While my intention is not to present a general study of other language-rights systems, existing approaches to language rights will be useful points of reference in developing my account, for two reasons. First, as noted above, the idea of participation is present in some extant models. The Canadian regime, in particular, interweaves the participatory and remedial objectives in an instructive fashion. Second, the language rights debates of societies with significant, vocal national minorities, like Canada and Spain, demonstrate that a particular language is more than instrumentally significant to its speakers-a significance that should be taken into account in building the American case. Though context matters to the appropriate resolution of a given language controversy, the rich and extensive literature that addresses the language questions of societies such as Canada and Spain will help illuminate the relationship between linguistic pluralism and politics and the law, even for an American writer primarily concerned with multilingualism in the United States. ${ }^{31}$

By exploring and then challenging the traditional terms of language rights debates-that such rights are group rights inconsistent with an assimilationist national identity-I attempt to dismantle the conceptual

30. Marc Shell, Language Wars, 1 New CENTENnIAL Rev. 1-4 (2001) (discussing the sources of language conflict, including the desire to create linguistically safe spaces).

31. Of course, some scholars who address those contexts have extended their discussion of language rights to consider the case of the immigrant. See, e.g., Ruth Rubio-Marin, Language Rights: Exploring the Competing Rationales, in LANGUAge Rights AND PolitiCal Theory, 52, 73-76 (Will Kymlicka \& Alan Patten, eds., 2003) (discussing the extension of certain types of language rights, which she calls "instrumental," to immigrants). 
assumptions that make it possible for Americans to conclude that language rights have no real place in our law. At the same time, I seek to demonstrate that fluid conceptions of participation available to multiethnic societies formed largely through immigration, like the United States, can improve the mediation of language diversity in countries populated by national minorities with strong historical claims to special status. This Article, in other words, sets out a generalizable framework for thinking about language diversity and its relationship to democracy.

In Part I of this Article, I explore the remedial thrust of the language law and policy of various legal systems around the world, including the United States, and establish why an alternative account must be developed. In Part II, I elaborate the participatory alternative. I explain the value of participation and identify the spheres of social life with which the participatory account should be concerned, establishing why we should prefer a multilingual rather than monolingual account of participation. I confront the claim that multilingualism produces social balkanization. In so doing, I address what I consider to be the most trenchant criticism of culture-based politics - that multicultural theories promote group survival, which in turn prevents groups from evolving and individuals from escaping the group identities they might prefer to abandon. I argue that language, as a cultural characteristic, is sufficiently flexible to ensure that different groups retain the ability and incentive to interact with one another in society's most important institutions, despite the persistence of multiple languages in a community. Embracing bilingualism in individuals and multilingualism in society will make real, rather than thwart, this possibility. I conclude, in Part III, by considering the United States as a case study, outlining a set of participatory practices for several American institutions-governmental bureaucracies, the workplace, and public schools. I suggest how the law that structures these institutions should be shaped, insofar as language is concerned, to accomplish participatory objectives. Through this discussion, it becomes clear that our participatory account should be multilingual rather than monolingual.

Throughout this Article, I draw on the existing terms of language rights discourse. The term language rights may be unfamiliar to many readers in the United States. Within academic and policy discussions, one school of thought regards language rights qua language rights as guarantees to specific language groups-guarantees such as the right to public education delivered in one's mother tongue, or the right to use one's native language in court proceedings. Under Canadian law, language rights have this meaning, as they belong only to Francophones and Anglophones and protect the right to use one's mother tongue in certain contexts. On the other hand, the concept of language rights also could be understood to refer not to substantive rights, per se, but to the means necessary to protect 
generally applicable rights in circumstances involving language minorities. The due process right to translation in criminal proceedings represents the classic example of this formulation. Providing such translation is a necessary part of protecting non-culture-specific, due process rights. Though this distinction may be important to the existing literature on language rights, it is ancillary to my project here. I am concerned with the impact of language difference on social institutions. I therefore use the term "language rights" in a more general sense-as a term that encompasses both the right to use the language of one's choice in certain contexts, as well as the interpretation of non-culture-specific rights in a manner that takes into account the linguistic and cultural dimensions of those rights. ${ }^{32}$

\section{LANGUAGE RightS as REMEDY}

Both scholarly and political discourses on language rights have been influenced considerably by a dichotomy commonly drawn between two different types of minorities: national minority groups with historical presence in a nation-state, and minority groups formed as the result of immigration. This dichotomy has facilitated the rise of a kind of orthodoxy, which holds that language rights as substantive rights belong primarily to the former. Whereas states may be obligated to support the preservation of once-threatened languages, immigrants, who by definition lack a historical relationship to the nation-state, are entitled to nothing more than assimilation to the dominant language on fair terms.

Language rights, under this formulation, serve as a kind of compensation or remedy for a nation's past attempts to destroy or suppress the culture of a national minority group. The language rights regimes of various societies around the world reflect this conceptualization. In parts of Europe and in Canada, for example, language rights constitute substantive rights that belong to particular minority groups, such as Catalans or French Quebeckers. These rights function to ensure their survival as groups, in the wake of a history of oppression or semi-coerced assimilation. In the United States, by contrast, a conception of language rights as substantive rights does not really exist. Though national minorities are present in the United States, we frame the language question as a matter of transitioning nonEnglish speaking immigrants, on fair terms, into a monolingual mainstream. To the extent that language conflict arises, the law channels that

32. I draw this distinction in response to Ruth Rubio-Marin's call to think of language rights not simply as "instruments of cultural protection," but also as rights that enable citizens to overcome linguistic obstacles. Rubio-Marin, supra note 31, at 53. She conceptualizes language rights as either instrumental or noninstrumental. The former ensure that language docs not create obstacles to the "effective enjoyment of rights with a linguistic dimension," and thc latter provide linguistic minorities with the "capacity to enjoy a secure linguistic environment in her/his mother tongue." Id. at 56. 
conflict through generally applicable antidiscrimination protections, and provides limited support for linguistic interests other than the interest in learning English. ${ }^{33}$

In this Part, I conclude that the remedial approach focused on ensuring minority group survival requires too much of the state and the public. At the same time, the promise made to immigrants of assimilation on fair terms requires too little. This conclusion need not lead to a rejection of the national minority paradigm and the corresponding remedial imperative completely. Both constructs, after all, will be quite relevant to protecting the interests of historically subordinated national minority groups and to securing the conditions for their survival. Rather, the limitations of the remedial conception underscore the need for an alternative vision of the interests of language minorities - an alternative 1 offer in Part 11. To make this necessity clear, I consider how regimes designed to secure the survival of national minorities have evolved, why a robust conception of language rights has not emerged in the United States, and why the national minority paradigm requires reformulation.

\section{A. Remediation, Revival, and National Minorities}

The remedial conception of language rights builds upon the assumption that national minorities-groups such as French-speaking Quebeckers and Catalan speakers in Spain-are entitled to linguistic recognition and resuscitation of their once-suppressed or threatened languages ${ }^{34}$ In societies with a history of such suppression, the evolution to a liberal, tolerant system of government historically has required a form of culture-based recognition as compensation for this past treatment. National minority groups' claims for recognition usually have taken shape as demands for equality of status, or for the declaration of co-official status for their language at some level of government. ${ }^{35} \ln$ some cases, the claims for recognition have been presented as demands for role reversal-for the oncethreatened language to be heavily favored over the once-dominant language. ${ }^{36}$ Because the minority language in question in many cases is emerging from an era of clandestine use, or a period of significant

33. See infra notes 60-70 and accompanying text (discussing the antidiscrimination framework with which law in the United States frames the issue of providing language assistance).

34. I refer to this version of remedial language rights as either the revival variation, because it focuses on the restoration of excluded languages, or the national minority paradigm.

35. See, e.g., infra notes 53-55, 124-126 and accompanying text (discussing the equal status principle in Canadian law).

36. See, e.g., infra notes 40 and 5 I (discussing the role reversal of Latvian and Russian after the dissolution of the Soviet Union). 
assimilation, even claims to equality have required considerable preferential treatment of the minority language. ${ }^{37}$

The policies of Spain, Latvia, and Canada reflect this commitment to language revival. Spanish law, ${ }^{38}$ for example, recognizes Spain's minority languages as national heritage languages that should be protected and preserved. ${ }^{39}$ This commitment acknowledges their historical marginalization dating back to the nineteenth century and to Francisco Franco's repression of minority languages during his decades of rule in the twentieth century. Similarly, the Soviet Union's Russification policies in Latvia have been invoked to justify a language law that aggressively promotes Latvian as the state's official language at the expense of the Russian minority within the

37. See, e.g., infra notes 40 and 51 (discussing preferential treatment given Latvian over Russian after independence from the Soviet Union); see also Charlotte Hoffmann, Balancing Language Planning and Language Rights: Catalonia's Uneasy Juggling Act, 21 J. OF MultilinguaL \& Multicultural Development 425, 439 (2000) (noting that "[f]rom a purely sociolinguistic perspective, efforts to counteract language shift require 'affirmative action' or 'proactive language policies' ... i.e., a form of positive discrimination"); see generally Josep Costa, Catalan Linguistic Policy: Liberal or Illiberal?, 9 Nations \& NATIONALISM 413 (2003) (discussing Catalonia's 1998 Language Act and assessing the controversy over whether its preferences for Catalan reflect illiberal tendencies). Instruments such as the European Charter for Regional or Minority Languages address past subordination by endorsing the adoption of affirmative action-type policies when needed to eliminate "unjustified" distinctions between dominant and minority languages. See European Charter for Regional and Minority Languages Part Il, art. 7, para. 2, Nov. 5, 1992, E.T.S. 148 (establishing that special measures aimed at promoting minority languages do not discriminate against speakers of more widely used language).

38. In addition to the constitutional provisions discussed above and below, several of Spain's autonomous communities-the subunits of Spain's federal system-have passed what are known as normalization laws, which promote the use of the region's minority language in all spheres of life, including education, public administration, and communication. See, e.g., Llei 1 de 7 de Gener, de Política Lingüística [Act No. 1, of 7th January 1988, on Linguistic Policy] (Generalitat of Catalonia), available at http://www6.gencat.net/llengcat/legis/en/lpl.htm; see also Costa, supra note 37, at 416-18 (discussing Catalonia's 1998 Linguistic Policy Act, its explanation of the political and demographic reasons for Catalan's current precarious position, and its objectives of promoting the use of Catalan in schools, media and cultural industries, and social and economic fields).

39. The Spanish Constitution expressly recognizes Spain's multilingual character:

1. El castellano es la lengua epañola oficial del Estado. Todos los españoles tienen el deber de conocerla y el derecho a usarla.

2. Las demás lenguas españolas serán también oficiales en las respectivas Comunidades Autónomas de acuerdo con sus Estatutos.

3. La riqueza de las distintas modalidades lingüisticas de España es un patrimonio cultural que será objeto de especial respeto y protección.

Constitución [C.E.] art. 3 (Spain) ("Castilian is the official Spanish language of the state. All Spaniards have the duty to know it and the right to use it. The other Spanish languages also will be official in the respective autonomous communities, in accordance with their Statutes. The wealth of Spain's different linguistic modalities is a cultural patrimony that will be the object of special respect and protection."). Note, however, that the role that language plays in the politics of the autonomous communities differs from context to context. For example, some scholars have noted that Basque nationalism has focused more on ethnicity-based politics than on linguistic identity. See, e.g., Ruth RUBIO-MARín, Lengua Y Ciudadania Multicultural: Una perspectiva constitucional 98 (forthcoming) (unpublished manuscript on file with author); Daniele Conversi, The Basques, the Catalans, and Spain: Alternative Routes to Nationalist Mobilisation 173-86 (1997). 
new state..$^{40}$ In Canada, the equal status given to the Francophone minority and the constitutional and statutory rights that stem from that status emerged in response to concern for the erosion of Francophone culture and power. In all three cases, however, the focus on revival has generated new forms of language conflict and exerted pressure on minorities within

40. For a general discussion of the Soviet experiment with national autonomy and the subsequent language policies that have arisen as a form of compensation in the Baltics, see Joseph Eliot Magnet, National Minorities and the Multinational State, 26 QUEEN's L.J. 397, 446-47 (2001). For a discussion of the effects of Latvia's language laws on the Russian minority, see Sonia Bychkov Green, Language of Lullabies: The Russification and De-Russification of the Baltic States, 19 Mich. J. INT'L L. 219, 223-36 (1997) (claiming that language laws in the Baltic states discriminate against the Russian minority in those states).

Despite Latvia's initial movement to deny minority language rights to Russian speakers, one of the conditions of Latvia's accession to the European Union was that it adopt "measures to facilitate the naturalisation process to better integrate non-citizens ... and enhancc Latvian language training for non-Latvian speakers," and that it respect the rights of the Russian-speaking minority. REGULAR RePORT FROM THE COMMISSION ON LATVIA's Progress TOWARdS ACCESSION 7, 13 (1998), http://europa.eu.int/comm/enlargement/report_11_98/pdf/en/latvia_en.pdf. From 1998 to 2003, an EU Commission monitored Latvia's treatment of non-Latvian speakers; the Commission included in its annual reports to the European Council observations on whether Latvia's language laws were in compliance with intemational human rights obligations. See, e.g., id. In the 1998 Report, for example, the Commission made note of efforts to remove from Latvia's language law "discriminatory provisions" that required use of Latvian in the private sector. See id. at 13-14. By the 2000 report, the Commission indicated that Latvia's Language Law was in conformity with Latvia's intemational obligations, as well as the European Agreement. See REgULAR REPORT FROM THE COMMISSION ON LATVIA'S PROGRESS TOWARDS ACCESSION 100 (2000), http://europa.eu.int/comm' enlargement/report_11_00/pdf/en/lv_en.pdf. For further discussion of the ways in which pressure from the Council of Europe led to the softening of Latvia's Language Law, see Pamela A. Jordan, Does Membership Have Its Privileges?: Entrance Into the Council of Europe and Compliance with Human Rights Norms, 25 Hum. RTs. Q. 660, 668-74 (2003) (describing the language conflict that followed independence, the international pressure that ensued, and the Latvian Parliament's eventual decision in 1999 to remove from the language law a requirement that citizens and businesses use only Latvian).

All of that said, language conflict has not subsided in Latvia. In its 2003 report, issued in the year of the Treaty of Accession, the Commission continued to emphasize that it strongly encouraged Latvia to "promote integration of the Russian minority by ... ensur[ingl sufficient flexibility regarding transition to bilingual education in minority schools, and to ensure that at all levels the implementation of the language law respects the ... public interest ... as well as Latvia's international obligations," suggesting that a gap existed between the formal requirements of the law and actual practice. See Comprehensive Monitoring Report on Latvia's Preparations for Membership 36 (2003), http://europa.eu.int/comm/enlargement/report_2003/pdf/cmr_lv_final.pdf. Indeed, despite the changes mentioned above, the 1999 law is still criticized for making Latvian the sole official language and for giving officials too much discretion in the enforcement of the law. See Jordan, supra, at 670. The persistent tension between the Latvian majority and the Russian minority is reflected in a 2002 challenge by a member of the Russian minority in the European Court of Human Rights to Latvia's clection law. See Podkolzina v. Latvia, App. No. $46726 / 99$ (Eur. Ct. H.R. Apr. 9, 2002), available at http://www.worldlii.org/eu/cases/ECHR/2002/405.html (holding that Latvia violated article 3 of Protocol No. 1 of the Human Rights Convention when the State Language Center forbade a Russianspeaking candidate from running for Parliament). In response to the court's decision, Parliament amended the constitution to heighten the status of Latvian. See Jordan, supra, at 673. In addition, controversy remains over the question of language education. See, e.g., Russian Diplomat Criticizes Rights Situation in Latvia Since EU Accession, BBC Monitoring, Sept. 7, 2004, at 1 (transcript of Radio Russia broadcast) (noting opposition to elimination of secondary education in Russian and sentiment among Russians in Latvia that there have been no positive movements in addressing language rights of Russians since Latvia's accession to the European Union). 
minorities, such as Castilian speakers in Catalonia, Russian speakers in Latvia, and Anglophones in Quebec.

In Spain, in particular, the constitution makes a commitment to defending the nation's linguistic heritage, ${ }^{41}$ but it declares Castilian the official language ${ }^{42}$ and delegates responsibility for protecting minority languages to the nation's autonomous regions. ${ }^{43}$ Indeed, the language question in Spain coincides with the country's particular version of federalism, or the devolution of political power to Spain's so-called autonomous communities. ${ }^{44}$ While this arrangement may make structural sense for Spain, it is not without potential difficulties. First, it puts the language minority at a distinct disadvantage in relation to Castilian speakers, because the arrangement means that Catalan and other recognized minority languages have no real status throughout Spain..$^{45}$ Second, because only Castilian has official status in the country as a whole, the arrangement provides a constitutional justification for Castilian speakers to eschew bilingualism in regions where a second language has official status alongside Castilian. ${ }^{46}$

41. Article 3 of the Spanish Constitution sets out the framework through which Spanish institutions manage multilingualisın and provides that "[t]he wealth of Spain's different linguistic modalities is a cultural patrimony that will be the object of special respect and protection." Constitución [C.E.] art. $3, \S 3$ (Spain) (author's trans.)

42. By formalizing Castilian as the lingua franca of modern Spain, article 3 of the constitution creates a universal right and obligation to speak and know Castilian and arguably impedes the resurrection of Spain's minority languages as public languages.

43. Article 3 of the constitution establishes that "[t]he other languages of Spain will also be official in the respective autonomous communities, in accordance with their Statutes," Constitucion [C.E.] art. 3, §2 (Spain) (author's trans.; emphasis added), which explicitly leaves the task of revival largely to the governments of the autonomous regions. See also Costa, supra note 37, at 415 (noting that " $[t]$ here is no clear constitutional obligation for the [Spanish central] state itself to promote or protect inultilingualism" and observing that while the central government generally respects linguistic laws passed by autonomous communities, it does not fully implement them in its own jurisdiction and actively promotes Castilian).

44. Spaniards generally understand such devolution as appropriate and inportant to the protection of Spain's minority languages, even though not all autonoinous communities contain large populations of minority-language speakers. See RuBIO-MARÍN, supra note 39, at 117.

45. See, e.g., supra note 42; see also Costa, supra note 37, at 415 (noting that, in its review of Galicia's Language Act, the Constitutional Court held that any attempt to establish by law a duty to know a language other than Castilian was unconstitutional). Whereas speakers of Castilian carry their language rights with thein throughout Spain, other language groups have no rights outside of the territories that have passed statutes to protect particular minority languages. See Costa, supra note 37, at 427 . What is more, the central government of Spain is largely monolingual. As a result, governınent agencies in Catalonia still controlled by Madrid operate primarily in Castilian. While sueh bureaucracies have achieved a degree of bilingualism, progress apparently reınains slow. By contrast, in those offices that the Statute of Autonoiny transferred to the Catalan government, officials administer services almost entircly in Catalan. See Miguel Strubell, Language, Democracy and Devolution in Catalonia, in Language, Democracy and Devolution in Catalonia 4, 30 (Sue Wright ed., 1999).

46. The extent to which the law supports this possibility is debatable. Although the constitution declares no duty of residents to learn a region's co-official language, some commentators have argued that the declaration of official status for a language-a constitutionally authorized act-presupposes a duty to know that language. For a discussion of this issue, see RUBIO-MARín, supra note 39, at 111-12. 
At the same time, the lack of federal support for the language revival creates potential problems for non-Catalan speakers living in Catalonia. The autonomous community has a distinct incentive to favor official monolingualism at the sub-state level, in the interest of giving the minority revival as much support as possible. Indeed, the 1998 language reform, with its emphasis on promoting the social, commercial, judicial, artistic, political, and financial use of Catalan, has proven controversial for its seemingly exclusive preference for Catalan. ${ }^{47}$ The legislation attempts to make Catalan not just a language of normal usage, but the predominant language in the public and social spheres. As scholars have emphasized, the 1998 law makes Catalan the language of all Catalonian institutions, from the schools, to political parties and unions, to private institutions operating in the public interest. ${ }^{48}$ Though Spaniards have associated the Catalan revival closely with the development of post-Franco Spanish democracy, liberal critics recently have protested that Catalonia's language policies, by promoting ethnolinguistic democracy, are anti-democratic. ${ }^{49}$ The Castilian minority in Catalonia may be the most directly disadvantaged by this preference, but the Catalan national minority group might also be disserved. The preference not only diminishes the incentive to learn and use the quite useful and more widespread Castilian language, ${ }^{50}$ it also fosters a potentially divisive ethnicity-based politics.

47. See Alan Yates, Response to Miguel Strubell, in LANGuAge, Democracy, ANd Devolution in Catalonia, supra note 45, at 62, 62-63.

48. See Rubio-Marín, supra note 39, at 91, 143.

49. See Strubell, supra note 45 , at 15 (quoting Francesco de Carreras) ("[E]sta política ... inspira una concepción nacionalista de Cataluña que, a mi modo de ver, no resulta conciliable con los principios de libertad y pluralismo en los cuales está basada nuestra dcmocracia constitucional.") ("This policy... inspires a nationalistic conception of Catalonia that, from my perspective, cannot be reconciled with the principles of liberty and pluralism on which our democratic constitution is based.") (author's trans.). Other critics have challenged laws requiring knowledge of Catalan in certain employment contexts on the ground that they violate the article 28 of the constitution, which guarantees freedom of movement-a basic liberal principle. See Strubell, supra note 45, at 26. In Canada, a similar tension betwcen non-language-specific constitutional provisions, such as the freedom of speech, and the language policies of federal entities has arisen with respect to a Quebec law that both the Supreme Court of Canada and the U.N. Human Rights Commission have declared an unconstitutional intrusion on the freedom of cxpression. For a brief discussion of this case, see infra notes 218-221 and accompanying text.

50. The Spanish Constitution's declaration of Castilian as the nation's official language lessens these dangers. All citizens reasonably can be expected to know the language. At least formally, the Catalan Generalitat must commit to the "normal and official use of both languages, adopt[ing] whatever measures are deemed necessary to ensurc both languages are known, and creat[ingl suitable conditions so that full equality between the two can be achieved as far as the rights and duties of the citizens of Catalonia arc concerned." Estatut d'Autonomia [Statute of Autonomy] art. 3, para. 3 (1979) (Generalitat of Catalonia). Catalonia's language normalization law recognizes Catalan and Castilian as official languages and provides that they "poden ésser emprades indistintament pels ciutadans $i$ ciutadanes en totes les activitats públiques i privades sense discriminació." See Llei 1 de 7 de Gener, de Política Lingüistica [Act No. 1, of 7th January 1988, on Linguistic Policy] art 3. (both official languages "may be used indiscriminately by citizens in all private and public activities without exception") (translation available at http://www6.gencat.net/llengcat/legis/cn/lpl.htm). The law also 
In comparison with Catalonia, the Baltic states' language policies highlight the dangers posed by laws focused primarily on revival to an even greater degree. The resurrection of Latvian as a public language has taken place in circumstances politically distinct from the revival of Spain's minority languages. After the dissolution of the Soviet Union, the entity responsible for the suppression of Latvian ceased to exist. Latvia's postindependence policies to establish Latvian hegemony, therefore, have not been in tension with the language policy of a central authority run by a linguistically dominant majority. In 1988, before independence, Latvia reestablished Latvian as its official Ianguage, but nonetheless retained certain "special rights" for Russian speakers. But in I992, free from Soviet oversight, Latvia eliminated those rights and began a newly aggressive promotion of Latvian. ${ }^{51}$ These changes in the law seemed to ignore the fact that more than $30 \%$ of the population remained tied to the Russian language. Today, the Russian minority continues to be a social force to be reckoned with. ${ }^{52}$ This experience thus underscores that reformulatimg institutions to promote the survival of the once-oppressed language creates new opportunities for language conflict.

Finally, Canada's language regime centers around a similar focus on language revival. In contrast to Spain and Latvia, authoritarian suppression of the minority language has not defined relations between Canada's two major language groups, pcrhaps with the exception of populations in the Western provinces. ${ }^{53}$ The Francophone minority, instead, has faced

establishes that the Generalitat must create circumstances such that the full equality of the two languages will be realized. See id. art. 4 (establishing that everyone in Catalonia is entitled to be proficient in both languages, to express themselves in both languages, and to be free from discrimination on account of official language used); see also supra note 38 . Nonetheless, because the specifics of language policy in Spain are, in practice, elaborated through the public laws of the autonomous regions, these external, constitutional constraints exist in tension with regional language politics. See supra note 47.

51. Ina Druviete, Language Policy in a Changing Society: Problematic Issues in the Implementation of International Linguistic Human Rights Standards, in LANGUAGE, A RIGHT AND a RESOURCE 264-65 (Miklós Kontra et al. eds., 1999). Article 4 of the 1992 Language Law, for example, provides that public servants and "persons wbo have everyday contact with the general public" use the official language. $I d$.

52. See Jordan, supra note 40 , at 669.

53. For instance, the Royal Commission on Bilingualism and Biculturalism (B \& B Commission) convened in 1963 to address a growing constitutional crisis rooted in the complexities of AnglophoneFrancophone relations. It pronounced Frencb a language imperiled by factors such as the disproportionatc assimilation of immigrants to English rather than French, see 1 ROYAL COMMISSION on Bilingualism and Biculturalism, Report of the Royal Commission on Bilingualism and Biculturalism 24 (1967), increasing assimilation of Francophones outside Quebec, economic inferiority of Francophones within Quebec, and lack of Francophone representation in the public service. See Richard Silver, The Right to English Health and Social Services in Quebec: A Legal and Political Analysis, 45 McGill L.J. 681, 693 (2000). In its Report, tbe Royal B \& B Commission noted the Canadian Constitution Act's ad hoc approach to language rights, the poor linguistic resources outside Quebec to serve minority Francophone populations, see RoYAl Commission on BILINGUALISM AND Biculturalism, supra, at 52-69, and the lack of a "fully developed linguistic régime expressing 
socioeconomic inequalities and the more benign threat of assimilation into the dominant Anglophone culture. ${ }^{54}$ Moreover, in negotiating the terms of the public revival of the French language, Canada has opted for an institutional model that stands, in many ways, as a counterpoint to the Spanish system. The 1982 Charter of Rights and Freedoms declares French and English to have equal status throughout Canada and obligates federal authorities across the country to promote that status. ${ }^{55}$ Yet, despite its differences from the Spanish system, Canada's contemporary language rights regime reflects a similar concern with addressing the demands of a group with a particular historical relationship to the nation-state and imposes some of the same costs. For example, the emphasis on resuscitation of French as a public language results in policies that sometimes obscure the interests of the Anglophone minority within the Francophone region of Quebec. $^{56}$

1 do not, of course, mean to suggest that these language regimes have taken shape as they have without good reason. In fact, to promote equality and stability generally, it may be necessary to permit the preferences described in these examples-at least until the once-dominated language has been revived to the point of stability, or the point at which the threat of assimilation has receded ${ }^{57}$ But the point of stability will be difficult to identify. More significantly, once it has been reached, a remedial conception of language rights, focused as it is on reviving a particular minority, provides little guidance with respect to how to treat minorities within the national minority, who may not want to assimilate. ${ }^{58}$ Finally, and perhaps most

the bicultural character of the country as a whole," id. at 69 , factors which threatened to consign Frcnch to a secondary status in contemporary Canada, despite its official equality with English.

54. See id.

55. Part 1 of the Constitution Act, 1982, being Schedule B to the Canada Act 1982, ch. 11 (U.K.), $\S \S 16-20$ (Can.) (establishing English and French as coequal official languages and the rights of individuals to use either language in proceedings before Parliament, in court proceedings, and in communications and interactions with federal institutions).

56. See infra notes $218-221$ and accompanying text (discussing case in which intcrest in promoting public use of French came into conflict with speech and commercial interests of Anglophone minority in Quebec).

57. Measures adopted by the Generalitat to secure the status of Catalan have included: requirements that all local authorities and public corporations of Catalonia use Catalan; civil service language training in Catalan; the promotion of public use of Catalan and the use of Catalan in higher education; linguistic requirements for public employers; and quota systems for private television and radio companies. See Llei 1 de 7 de Gener, de Política Lingüistica [Act No. 1, of 7th January 1988, on Linguistic Policy] art. 9 (language of government); $i d$. art. 11, para. 2 (civil service training); $i d$. art. 11 (public employment); id. art. 22 (university education); id. art. 26 (quota system for television and radio). In the context of these measures being passed, it has been suggested that "[o]ne could argue that it is no longer necessary to implement language policies in order to support Catalan identity-this identity is already quite well established." Hoffmann, supra note 37, at 439.

58. Cases such as Latvia's, where no national legal authority (perhaps only political pressure from Russia) protects the Russian-speaking minority, exemplify this conccrn. The obvious response is that the demands of remediation justify a language policy designed to promote the complete assimilation of the new language minority. As noted above, such a policy would not be an option in 
importantly, the idea of revival does not address the linguistic challenges presented by immigration, which is a highly relevant phenomenon for many societies with large national minorities, including Spain and Canada. Indeed, the development of language politics in Canada, as a two-language question, renders the Canadian system incapable of accounting for the potentially valid claims and interests of minority groups other than Francophones. ${ }^{59} \mathrm{We}$ require something more.

\section{B. Remediation and Antidiscrimination}

Language diversity long has been a defining feature of the United States' demography, and language conflict therefore has appeared throughout American history. The American legal system has not ignored the linguistic interests of non-English speakers, but, in contrast to Europeans and Canadians, Americans have not addressed this conflict by making a strong national commitment to the survival of particular language minorities. Though the population of the United States always has included groups that fit the definition of national minority-Native Americans, Mexican Americans in the Southwest, Puerto Ricans, and Hawaiians-the law either has treated them as special cases or elided their linguistic interests. Our legal system's basic approach to language difference, instead, enlists the immigrant seeking assimilation on nondiscriminatory terms to serve as the paradigm case ${ }^{60}$ For reasons that I will explain, this approach does not generate a sufficiently substantive account of multilingualism. But the response to this inadequacy should not be to adopt the survivalist impulse reflected in the national minority paradigm. Instead, the inadequacies of that paradigm, particularly for a society like ours whose language diversity has resulted in substantial measure from immigration, underscore the need for an alternative to extant conceptions of language rights. But before an alternative account can be developed, we must understand the American system in more detail.

Catalonia, because of the Spanish Constitution's declaration of Castilian as the national language and its provision that "all Spaniards have the duty to know it and the right to use it." Constitución [C.E.] art. 3, para. 1 (Spain). Even if this guarantee did not exist, Catalonia's presence in a larger Castilianspeaking union virtually guarantees the presence of a sizable population of native Castilian speakers, most of whom are likely to be unwilling to lose their linguistic connection to the rest of Spain.

59. C. Michael Macmillan, The Practice of Language Rights in Canada 180-202 (1998) (discussing the interests of speakers of languages other than French and English).

60. This paradigm includes cases, like Meyer v. Nebraska, that protect the rights of individuals in the private spherc to use the language of their choice. See, e.g., Yu Cong Eng v. Trinidad, 271 U.S. 500, 524-28 (1926) (holding that Philippine Bookkeeping Act, which prohibitcd keeping of accounts in languages other than English, Spanish, and Philippine dialects, violated Philippine Bill of Rights, patterned by Congress after U.S. Bill of Rights, on grounds that it deprived Chinese merchants in Philippines of due process of law); Meyer v. Nebraska, 262 U.S. 390, 400-03 (1923) (striking down state statute forbidding foreign-language instruction in public schools until after eighth grade on due process grounds). 
Courts and lawmakers in the United States have tended to view language difference in transitional and antidiscrimination terms and have focused on ensuring that non-English speakers receive adequate resources to overcome language barriers. The law relies on antidiscrimination language to frame this form of assistance and sometimes regards the failure to accommodate a non-English-speaking minority as discrimination on the basis of race or national origin. But once the language barrier has been overcome, the language minority ceases to have legal status as a language minority.

More specifically, since the passage of the Civil Rights Act of 1964, American law has recognized the linguistic interests of non-English speakers by requiring that certain institutions affirmatively assist them. In 1974, for example, the Supreme Court held that a public school's failure to address its students' language barriers potentially constituted national origin discrimination, essentially concluding that Title VI guarantees a "right" to learn English in the public schools. ${ }^{61}$ Though the continuing validity of this holding is in doubt for reasons unrelated to the specific rights of language minorities, ${ }^{62}$ the case and subsequent congressional regulations reflect a commitment to protecting non-English speakers' interests through antidiscrimination law. ${ }^{63}$ Even more recently, in the waning days of the Clinton administration, the Department of Labor published policy guidelines clarifying its position on the obligations of recipients of federal financial assistance to accommodate "persons with limited English proficiency" in the workplace. ${ }^{64}$ The memorandum accompanying the executive order framed the guidelines as enforcing the prohibition on national origin discrimination in Title VI. ${ }^{65}$ Similarly, guidelines of the Equal Employment

61. See Lau v. Nichols, 414 U.S. 563 (1974).

62. Since 1974, the Court has declared Title Vl to be coterminous with the Equal Protection Clause. Further, the Court also has held that Title Vl does not authorize individuals to bring enforcement actions - the mechanism through which Kimminey Lau brought the case of the Chinese schoolchildren to the federal courts in Lau v. Nichols. See Alexander v. Sandoval, 532 U.S. 275, 285, 293 (2001) (holding that Title VI does not create freestanding private right of action to enforce disparate-impact regulations and making clear Court's rejection of Lau's interprctation with respect to reach of Title VI); Regents of Univ. of California v. Bakke, 438 U.S. 265, 351 (I978) (suggesting that failure to accommodate language group without demonstrated connection to race might not be illegal).

63. See, e.g., Equal Educational Opportunities Act, 20 U.S.C. $\$ 1703$ (f) (1994) (making unlawful failure of educational agency to take appropriate action to overcome language barriers impeding equal participation by students in instructional programs).

64. Exec. Order No. 13,166, 65 Fed. Reg. 50,12I (Aug. I6, 2000).

65. Policy Guidance on the Prohibition Against National Origin Discrimination as It Affects Persons With Limited English Proficiency, 66 Fed. Reg. 4,596 (Dep't of Labor Jan. 17, 200I) ("Bccause of language differences and the inability to speak or understand English, LEP persons are often excluded from programs and activities, experience delays or denials of services, or receive assistance and services based on inaccuratc or incomplete information. Such exclusions, delays or denials may constitute discrimination on the basis of national origin..."). The memo describes ccrtain pervasive practices, such as the reliance on a claimant's minor children to translate instead of engaging a professional translator to assist in the delivery of government benefits or services, as 
Opportunity Commission interpreting Title VII treat English-only workplace rules imposed by employers on employees as potential instances of national origin discrimination. ${ }^{66}$

On the one hand, though these administrative efforts are couched in the formal language of national origin and antidiscrimination, they target for improvement the status of language minorities, and they are accommodationist in nature. These policies require public entities to structure their institutions to make linguistic space for language minorities. ${ }^{67}$ At the same time, the assistance is designed to enable minorities' transition to the English-speaking mainstream, not to recognize any substantive linguistic rights. Language minorities qua language minorities have no status under antidiscrimination law. The Civil Rights Act of 1964 does not include language in its list of protected classes, and the Supreme Court has declined to recognize language as a suspect classification in Fourteenth Amendment jurisprudence. ${ }^{68}$ Courts thus treat the question of language discrimination as a form of potential racial or national origin discrimination. The general consequence of this framing is that language minorities receive the protection of the antidiscrimination laws only in circumstances in which their status seems immutable. And courts consider language to be immutable only until the ability to speak English has been acquired.

This formulation is apparent in the cases examining whether an employer's English-only policy, or rule that non-English languages may not be spoken in the workplace, violates Title VII. Many courts facing Title

potential violations of Title VI. See also Gutierrez v. Mun. Ct., 838 F.2d 1031, 1045 (9th Cir. 1988), vacated as moot, 490 U.S. 1016 (1989) (striking down "English-only rules [that] generally have an adverse impact on protected groups and ordinarily constitute discriminatory conditions of employment").

66. See Speak-English-Only Rules, 29 C.F.R. § 1606.7(a) (2005) (providing that blanket Englishonly rule presumptively violates Title VIl as "a burdensome term and condition of employment"); see also EEOC Compl. Man. (CCH) $\S 623$ (discussing speak-English-only rules and other language policies). In recent years, the EEOC has been active in enforcing these regulations. Complaints to the EEOC with respect to workplace English-only rules quintupled from 1996 to 2000 . The agency partly attributes the rising number of complaints to the outreach work of its national origin task force, and the agency has settled a number of these claims successfully. Maria Shim, English-Only Workplace Suits Continue to Rise, The RECORDER, Oct. 18, 2000, at 3.

67. In 2003, the New York City Council passed the Equal Access to Human Services Act, amending the city's administrative code to requirc city agencics and their contractors to provide free language-assistance services to limited English proficient individuals. See New York City Local Law No. 73 , Ch. 10, § 8-1003 (2003). In its declaration of legislative intent, the council took note of its obligation, as a recipient of federal funds, under Title VI of the Civil Rights Act of 1964, to take "reasonable steps to ensure meaningful access to the information and services [provided by the City]." The Council noted that it was enacting the translation requircments to "ensure that persons eligible for social services receive them and to avoid the possibility that a person who attempts to access services will face discrimination based upon the language s/he speaks." Id. $\S 1$. For other examples of accommodation requirements that spring from interpretations of Title VIl, see supra note 64 .

68. Hernandcz v. New York, 500 U.S. 352, 370-72 (1991) (holding that prosccutors could strike potential jurors based on fluency in another language without violating Batson v. Kentucky, 476 U.S. 79 (1986), because language and race, in this particular case, could be distinguished). 
VII challenges to such rules have concluded, despite EEOC regulations to the contrary, that they do not have a disparate impact on bilingual employees, even though workers who speak no English at all might have colorable claims. ${ }^{69}$ The implication of these holdings is twofold. First, the courts seem open to the idea that English-only rules might harm a non-English speaker; his linguistic identity is constructively immutable, because at the time of the rule's imposition his inability to speak English cannot be altered. Second, the courts have concluded that even if English-only rules disproportionately affect English-speaking national origin minorities, the impact they experience is not legally cognizable. In other words, whatever harms they feel do not constitute the harms policed by Title VII. The bilingual can choose which language to speak, and his identity is therefore mutable. Knowledge of English reflects the fact that a language barrier has been crossed; the process of assimilation removes the protection of the law.

I discuss the merits of these conclusions in Part III, ${ }^{70}$ but if we assume that the suppression of Ianguages other than English in public spaces is cause for concern, the current law's treatment of the issue offers an inadequate framework. Reliance on antidiscrimination law to channel languagerelated issues has stymied the development of a complete understanding of the social significance of language, or an understanding that reaches beyond the language minority's interest in acquiring the dominant language. Because the antidiscrimination justifications for accommodationist policies are not connected to a substantive conception of the social status of language, our policy discourse is impoverished.

Put slightly differently, reliance on the Ianguage of race discrimination to justify Ianguage accommodation distorts the terms of the policy debate. Framing language accommodation as a response to race discrimination makes it difficult to justify language policy to lawmakers who understand language and race to be distinct phenomena. Moreover, the role that language plays in social life is difficult to square with the constitutionaI doctrines that have emerged to assess racial classifications. As human interaction must occur in language, it is impossible to resolve the language question by concluding that the state can be blind to that characteristic, particularly when speakers of multiple languages populate the public sphere. ${ }^{71}$ Whereas American equal protection law revolves around the

69. See, e.g., Garcia v. Spun Steak Co., 998 F.2d 1480, 1487 (9th Cir. 1993) ("1t is axiomatic that 'the language a person who is multi-lingual elects to speak at a particular moment is . . a matter of choice." (quoting Garcia v. Gloor, 618 F.2d 264, 270 (5th Cir. 1980))) (emphasis added); Gloor, 618 F.2d at 269 (asserting that Title VIl was not intended to protect characteristics over which individuals exercise control, and emphasizing that civil rights laws do not "prohibit all arbitrary employment practices," but rather focus on prohibiting discrimination on basis of traits that are "beyond the victim's power to alter").

70. See infra notes 253-268 and accompanying text.

71. Patten, supra note 26, at 693. 
principle that race has no inherent relevance to a person's capacity to participate in social life, language, with its behavioral and social characteristics, shapes that very capacity. As a result, linguistic diversity cannot be deemed a purely private or personal phenomenon, as one might characterize certain aspects of culture or religion. Relying conceptually on a body of law that rejects the social significance of race is counterproductive to a policy discourse that must fully embrace language differencc, whether the desired end is monolingualism or multilingualism. ${ }^{72} \mathrm{We}$ may reach the ultimate conclusion that the public sphere should be monolingual. But that conclusion cannot be based reasonably on the assumption that the speaking of language is a matter of purely private concern.

\section{Rethinking the Remedial Paradigm}

In many ways, the American approach to language difference stands in sharp contrast to the language regimes of other constitutional democracies. The latter guarantee substantive rights to secure the interests and survival of national minorities. National minorities do exist in the United States. But our language rights discourse revolves around the transitional interests of immigrants and the importance of their rapid acquisition of English-language skills. Despite this core difference, however, all of the systems I have discussed share a basic assumption: the cultural interests of national ninorities and immigrants are distinguishable. This distinction, which I call the "national minority paradigm," embodies a powerful impulse that pervades national and international law ${ }^{73}$ alike- the impulse to distinguish between the historically present minority and the new arrival. Whereas the linguistic culture of the former is to be preserved, members of the latter group must assimilate. ${ }^{74}$

In this Section, I challenge the presumption that substantive language rights belong only to particular national minorities and make clear why the

72. Were American constitutional law to make a turn toward a culture- or behavior-based approach to race, then the analogy of language to race might be more useful. But the wisdom of such a turn is well beyond the scope of this Article. For present purposes, the crucial point is that the current treatment of language minorities has resulted in an impoverished conception of the social significance of language. For an excellent critique of the colorblind view, in the wake of which the race and language parallel would become more viable, see Neil Gotanda, A Critique of "Our Constitution Is Color-Blind," 44 STAN. L. REV. 1, 18 (1991).

73. See, e.g., European Charter for Regional and Minority Languages Part 1, art. 1, para. a, Nov. 5,1992 , E.T.S. 148 (protecting languages "traditionally used within a given territory of a State by nationals of that State," and "not ... the languages of migrants").

74. Some scholars have suggested that certain types of language rights need not be thought of as strictly belonging to national minority groups. In drawing a distinction between instrumental language rights, or rights designed to help language minorities overcome linguistic obstacles, and noninstrumental rights, or rights intended to securc the "linguistic environment" of language minorities, Rubio-Marin concludes that there is "no reason to limit the instrumental rights to autochthonous national minorities, no matter how broad the consensus that only those groups should be accorded noninstrumental language rights." Rubio-Marín, supra note 31, at 73. 
linguistic interests of non-national minorities should be the subject of a theory of language difference. I do not claim that we should discard the national minority paradigm, for it provides a useful means of cabining claims to territorial sovereignty, self-determination, and minority-run institutions. Furthermore, national minorities and immigrants do have different interests and are differently positioned in relation to the nation-state. ${ }^{75}$ Instead, in challenging the national minority/immigrant dichotomy, I emphasize that immigrants often have cultural interests that resemble those of national minorities. I therefore seek to discredit the idea that language rights discourse has no place in U.S. law and to demonstrate a need for a conception of language rights different than either of the ones just explored.

The national minority paradigm requires rethinking for at least three reasons. First, at the core of the distinction between immigrants and national minorities rests an oversimplified assumption about human agencythat immigrants have chosen to abandon their culture of origin. As one scholar has framed it, immigrants are cultural minorities as a result of choices they have made, and they therefore have "no right-based claim to ... [the] protect[ion of] their heritage culture. ${ }^{.76}$ As Will Kymlicka explains, "National minorities have resisted integration and fought to maintain or rebuild their own societal culture, while immigrants have accepted the expectation they will integrate into the dominant societal culture."77 Indeed, the major immigrant countries of the West, including the United States, have managed over the past 150 years to integrate extraordinary numbers of immigrants without substantial risk to their stability or national unity. This reality reflects a strong historical tendency toward integration, as well as acceptance by immigrants that they must integrate into the dominant culture. ${ }^{78}$

75. The national minority paradigm has the advantage of appealing to advocates of judicial restraint. For example, in interpreting the right to have courtroom proceedings conducted in the language of one's choice, the Supreme Court of Canada cited the genesis of language rights in the Anglo-Franco political bargain in concluding that the right to speak both official languages in federal court did not include the right to be understood, meaning that simultaneous interpretation provided adequate linguistic accommodation. See Ass'n of Parents for Fairness in Educ. v. Societé des Acadiens du Nouveau-Brunswick, [1986] 1 S.C.R. 549, 555-56 (Can.).

76. Joseph Heath, Immigration, Multiculturalism, and the Social Contract, 10 CAN. J.L. \& JuRIS. 343, 355 (1997); see also MACMILlaN, supra note 59, at 189 (arguing that immigrants make a particular choice that involves ceding claims to language guarantees).

77. Will Kymlicka, Politics in the Vernacular: Nationalism, Multiculturalism and Citizenship 156 (2001). To be sure, Kymlicka does advocate that immigrants be integrated on "fair terms" and outlines a number of proposals for culturally aware integrationist policies that "respect...the identities of ethnocultural minorities" while encouraging them to participate in mainstream institutions. See id. at 162-63.

78. Id. at 152-56; see also Michael Walzer, Comment, in Multiculturalism 99, 103 (Charles Taylor ed., 1994) ("[Immigrants] intended (and still intend), were prepared (and still are prepared), to takc cultural risks when they came here and to leave the certainties of their old way of life behind."). 
The simplicity of this claim has a certain resonance, and the process of migration, when viewed from a distance, does suggest that assimilation is inexorable. But the cultural reality of immigration is far more complicated than an abstracted sense of history permits us to see. It has become commonplace to note that various factors, sometimes referred to as a "push-pull" dynamic, lead people to migrate to countries like the United States. These factors include economic necessity, war and persecution, the desire for greater educational or professional opportunities, or the failure of migrants' own states to provide the conditions for living a meaningful life. ${ }^{79}$ Migration is also often a function of a "history of prior contact between sending and receiving societies." ${ }^{\circ 0}$ This feature of migration suggests not only that the receiving society has participated in some way in the conditions that generated the migration, but also that migration is not generally about abandonment. Immigrants cannot but be aware that cultural dislocation awaits them, but they may also expect to find family members and culturally and linguistically familiar communities in receiving societies. In fact, studies document migrants' tendency to gravitate to particular places in receiving societies because of the social networks that exist there to support them. ${ }^{81}$

Migrants ultimately conceive of their relationship with the host society in a wide variety of ways. ${ }^{82}$ A growing academic literature documents that immigrants to countries like the United States increasingly forge "transnational ties," or live a "transnational lifestyle." They act with the intention of "participat[ing] in the political and economic lives of their homelands, even as they are incorporated into their host societies." ${ }^{83}$ Contributing to this phenomenon, "homeland" societies facilitate the retention

79. See Thomas Holzer, Gerald Schneider, \& Thomas Widmer, The Impact of Legislative Deterrence Measures on the Number of Asylum Applications in Switzerland (1986-1995), 34 INT' $^{2}$ Migration Rev. 1182, 1187 (2000) (describing "the 'push' and 'pull' factors [that] simultaneously contribute to migration"). For a critique of economic push-pull theories, see Alejandro Portes \& József Böröcz, Contemporary Immigration: Theoretical Perspectives on its Determinants and Modes of Incorporation, 23 INT'L MIGRA TION REV. 606, 607 (1989) (arguing that push-pull theories that explain migration as the outcome of poverty in the sending countries are misguided).

80. Portes \& Böröcz, supra note 79 , at 608.

81. See id. at $612-13$.

82. Cf. Bhiku Parekh, The Rushdie Affair: Research Agenda for Political Philosophy, in THE Rights of Minority Cultures 303, 311 (Will Kymlicka ed., 1995) (“[Immigrants] stand in different historical and contractual relations to the receiving country. Again, some immigrants are or see themselves as short-term residents anxious after a few years to return to their countries of origin or to move elsewhere; some are or see themselves as long-term residents anxious eventually to return to their countries of origin and in the meantime to remain and work within, but not to become full members of, the host society; some others want to remain members of their countries of origin as well as become full members of the host country; yet others have completely broken with countries of origin.").

83. Peggy Levitt, The Transnational Villagers 3 (2001); see also id. at 15-21 (discussing the various theories and manifestations of "transnationalism"). 
of dual identity through a variety of legal mechanisms that enable migrants to remain political participants in their countries of origin. ${ }^{84}$

Ultimately, the phenomenon of migration is too complex to advance any single conclusion about migrants' intent. Indeed, given the changes in migration patterns noted in Part $I,{ }^{85}$ the rapid assimilation story that characterized the German, Italian, and Jewish immigrations to the United States may turn out to be historically anomalous, and not the paradigm case. ${ }^{86}$ In other words, immigrants today more closely resemble national minorities in their expectations than they do their predecessors of the late nineteenth and early twentieth centuries. What is more, as Kymlicka suggests, it was not until the post-civil rights era that a culture of tolerance that permitted difference to flourish prevailed in North America ${ }^{87}$ - a political culture that changes the terms of immigrants' arrival by making it easier for them to retain a connection to their cultures of origin than in the past. If we shift our frame of reference from the borders of the United States to a more global perspective-a shift in orientation called for because of changes in trade and labor relations-then today's immigrants stand similarly positioned to the groups conventionally described as national minorities. The claim that immigrants ought to assimilate may still be valid. But that claim cannot be based on a foundation of consent.

The second reason to reconsider the national minority paradigm stems from the universal salience of linguistic identity. Even those systems that ground language rights on a concept of historical desert also elaborate the content of those rights in terms of the universally applicable attributes of language. Take Canada as an example. On the one hand, to define the language regime's scope, Canadian courts and politicians frequently make the claims that Anglophones and Francophones constitute Canada's "founding people," and that the very concept of language rights arose from the political compromise that formed the confederation. ${ }^{88}$ The Canadian Charter's declaration of equal status for French and English supports the idea that language rights recognize these two groups' status as original, founding,

84. See id. at 19. The Congress of the Dominican Republic has considered creating a legislative seat that would represent migrants. "Mexico, Colombia, Brazil, Ecuador, and Portugal, to name a few, have all amended their constitutions to include migrants as official members of their political communities, though each country grants them different political rights." Id.

85. See supra notes 21 and 23 (discussing ways in which replenishment of minority groups through ongoing immigration will change characteristics of ethnic identification).

86. 1 owe this formulation to Noah Feldman.

87. See K.YMLICKA, supra note 26 , at 14.

88. See, e.g., Ass'n of Parents for Fairness in Educ. v. Societé des Acadiens du NouveauBrunswick, [1986] 1 S.C.R. 549, 555-56 (Can.) (noting that language rights remain founded on a political compromise). For a discussion of the founding peoples view in Canadian jurisprudence, see Denise G. Réaume, The Demise of the Political Compromise Doctrine: Have Official Language Use Rights Been Revived?, 47 McGiLl L.J. 593, 598-601 (2002). 
historically entrenched people ${ }^{89}$ This historical justification has emerged alongside a discourse of stability and national unity. ${ }^{90}$ The argument that language rights have emerged to solidify a political compromise has led the Supreme Court of Canada to find that language rights "lack the universality, generality and fluidity of basic rights resulting from the rules of natural justice," ${ }^{\prime 11}$ precisely because they represent a narrowly defined set of specific provisions created to give legitimacy to a political reconciliation. ${ }^{92}$

At the same time, the court, despite its emphasis of the founding moment, has acknowledged that language rights function as mechanisms of reconciliation only because they embody an appreciation of language's value to individuals and groups..$^{93}$ Language rights amount to more than a simple set of clearly defined prescriptions articulated in a constitutional compromise; they embody a concept with evolving content. Defining the scope of language rights has required the court to interpret them in light of the role language plays in the creation of individual and group identity generally, not just in the context of the Anglo-Franco political bargain. The Supreme Court of Canada has emphasized repeatedly that "[l]anguage ... colours the content and meaning of expression" and serves as the vehicle for expression of individual identity. ${ }^{94}$ Members of the court have drawn a connection between the language one speaks and the process of human development, emphasizing that language "bridges the gap between isolation and community, allowing humans to delineate the rights and duties they hold in respect of one another, and thus to live in society. ${ }^{295}$

89. See Part 1 of the Constitution Act, 1982, being Schedule B to the Canada Act 1982, ch. 11 (U.K.), § 16 (Can.) (establishing English and French as coequal official languages).

90. Though the two should not be confused, they tend to reinforce one another and to entrench the national minority paradigm. See, e.g., Pierre Trudeau, Prime Minster of Canada, House of Commons Debate (May 31, 1973) (arguing that language rights are protected "[n]ot primarily because of any historical founding rights.... We are dealing with straightforward political and social realities ... . If only because of sheer force of numbers, either group has the power to destroy the unity of this country.") (quoted in MACMILLAN, supra note 59, at 168).

91. MacDonald v. Montreal, [1986] 1 S.C.R. 460, 500 (Can.).

92. See, e.g., Fed'n Provinciale des Comites de Parents, lnc. v. AG of Manitoba, [1993] 1 S.C.R. 839, 851 (Can.); Reference re Section 79(3), (4), and (7) of the Public Schools Act of Manitoba, [1990] 67 D.L.R. 4th 488, 559-60 (O'Sullivan, J.A., concurring) (Can.), rev'd, [1993] 100 D.L.R. 4th 723. For examples of the restrained approach to the interpretation of language rights taken by the court in the 1980s, see MacDonald, [1986] I S.C.R. at 460 (holding that issuance of unilingual summons in French to English speaker did not violate s. 133's provision that either French or English may be used by any person or in any pleading or process issuing from any Court of Canada or Quebec) and Ass ' $n$ of Parents for Fairness in Educ., [1986] 1 S.C.R. at 549 (holding that right to use either official language in court proceedings did not include right to be understood).

93. For a discussion of the Supreme Court of Canada's move away from the political compromise doctrine in favor of a more robust reading of the Charter's language guarantees in all contexts, including in the courtroom, see Réaume, supra note 88, at 593.

94. Ford v. Quebec, [1988] 2 S.C.R. 712, 716 (Can.).

95. Ass'n of Parents for Faimess in Educ., [1986] 1 S.C.R. 549, at 563 (Can.) (internal citation omitted) (Dickson, C.J., concurring); see also R. v. Beaulac, [1999] 1 S.C.R. 768; 786 (Can.) 
Under this view, the reason language rights offer a viable means through which to secure political compromises is that they acknowledge the fundamental role language plays in creating and sustaining social ties, and they incorporate a core feature of a group's cultural practices into the constitutional foundations of the nation. As Canadian scholar C. Michael Macmillan explains, the importance of language rights "depends on the place of language in the daily life and self-definition of the cultural community." "Though these rights are not "supremely sacred," they resemble fundamental human rights in important respects and have significance for language groups "that goes beyond the historical particularity of "compromise rights.",97 The conclusion that immigrants can expect to recreate their cultural practices only informally, or without institutional support, ${ }^{98}$ coheres with the liberal rhetoric of neutrality. ${ }^{99}$ But it is in tension with what I take to be multicultural theory's key contribution to the liberal perspective-that cultural affiliations are relevant to people's abilities to find their way to the good life and to make complete political and social choices. ${ }^{100}$ This understanding of culture applies no less to immigrants than to long-entrenched national minorities. This catholicity underscores the limitations of grounding language rights in long-standing territorial or historical claims.

A tension thus exists between this universalistic, dignitary conception of the significance of language and the equation of language rights with groups possessing a particular historical pedigree. ${ }^{101}$ Even in societies where the national minority paradigm cannot be escaped, it seems that culture-based rights, to be meaningful, must be justified in light of the nature of culture and its relationship to participation in social life, not just as the result of a hierarchy based on historical presence. ${ }^{102}$ Put slightly differently,

(Bastarache, J.) (citing Ass'n of Parents for Fairness in Educ., [1986] 1 S.C.R. at 560 (Dickson, C.J., dissenting))

96. MACMILLAN, supra note 59, at 22.

97. Id.

98. See, e.g., Heath, supra note 76 , at 355.

99. See Amy Gutmann, Introduction, in Multiculturalism 3, 10 (Charles Taylor ed., 1994). ("Liberal democracy is suspicious of the demand to enlist politics in the preservation of separate group identities or the survival of subcultures that otherwise would not flourish through the free association of citizens.").

100. See discussion infra notes 150-156 and accompanying text (discussing the affective case for participation through an articulation of basic principles of multicultural theory).

101. One of liberalism's compelling features is its regard for the "moral unity of the human species" and its accordance of "secondary importance to specific historic associations and cultural forms." Chandran Kukathas, Are There Any Cultural Rights? in THE Rights OF MiNORITy Cultures, 228, 231 (Will Kymlicka ed., 1995). Kukathas also points out that "[g]roups or cultural communities do not exist prior to or independently of legal and political institutions but are given shape by those institutions." Id. at 232. This again suggests that claims for recognition should not depend on some kind of historical status, because that status is itself constructcd, not inherent.

102. See, e.g., Sujit Choudhry, National Minorities and Ethnic Immigrants: Liberalism's Political Sociology, 10 J. Pol. PHIL. 54, 56 (2002) (observing that in "liberal democracies, differentiating among 
whereas a group's status as a national minority clearly has political significance, ${ }^{103}$ this status has limited moral significance. The status does not entitle national minorities to any greater respect of their cultural interests than would be owed to them as culture-bearing individuals. Historical realities may shape the form that equal respect takes, or the specific institutional responses a system adopts to manage cultural controversies, but they do not provide moral justification for limiting the respect to national minorities. Injecting a universalistic ethos into the effort to accommodate language differences "does not necessarily exclude consideration of historical conditions, but it refocuses such consideration into a larger assessment of the requirements for the present-day realization of human values."104 Under this view, history becomes a useful resource for crafting politically viable policies, not a reason for according recognition to a group's language in the first instance.

The final reason to rethink the distinction drawn between immigrant societies and societies populated by national minorities is that these societies are often one and the same. In the United States, for example, national minorities always have been a part of the population. To be sure, the sociolinguistic consensus holds that communities of non-English speakers in the United States are fed more by present-day immigration than by "language maintenance" among national minority populations. ${ }^{105}$ But the presence of national minorities is inescapable. Native Americans, in particular, have acute linguistic interests, as many of their surviving languages face extinction. ${ }^{106}$ In many cases, national minorities are not distinguishable from

citizens simply on the basis of prior membership, without additional justification ... appears to contradict the basic liberal commitment of giving equal importance to the interests of every citizen").

103. During a debate in the House of Commons in 1973, former Canadian Prime Minister Pierre Trudeau explained the justification for official bilingualism in Canada as follows: the Francophone minority must be recognized as equal in Canada "not primarily because of any historical founding rights, though they are important to many people .... We are dealing with straightforward political and social realities ... [that] leave Canada with only one choice, only one realistic policy: to guarantee the language rights of both linguistic communities." Trudeau, supra note 90 (quoted in MACMlLLAN, supra note 59 , at 168 ).

104. S. James Anaya, The Capacity of International Law to Advance Ethnic or Nationality Rights Claims, in The Rights of Minority Cultures 321, 327 (Will Kymlicka ed., 1995); cf. Avishai Margalit \& Joseph Raz, National Self-Determination, in THE RigHts OF MINORITY CULTURES 79, 88 (Will Kymlieka ed., 1995); ("But a history of persecution is neither a necessary nor a sufficient condition for the instrumental case for self-government .... [P]ersecution is not the only reason why the groups may suffer without independence.... [T] here may be other ways to fight and overcome persecution[,] and... independence... may lead to economic decline, cultural decay, or social disorder, which only make their members worse off.").

105. See Richard Y. Bourhis \& David E. Marshall, The United States and Canada, in HANDBooK OF LANGUAGE AND EThNic Identity 244, 250 (Joshua A. Fishman ed., 1999).

106. Because claims made by indigenous peoples around the world stem from similar histories marked by colonial drives to extinguish native populations, either physically through military conquest or culturally through coerced assimilation, the remedy of cultural revival seems a natural response. While the claim to remediation of historical injustice represents only one of the many types of claims indigenous activists can and have asserted, see Benedict Kingsbury, Reconciling Five Competing 
immigrants. In the United States, for example, immigration is not the sole source of the Latino population. The Southwest was Mexico until the Treaty of Guadalupe Hidalgo of 1850, and the current "Mexican American" populations of the region have inhabited their territory since long before statehood. These groups legitimately qualify as entrenched national minorities. Similarly, Puerto Ricans in the United States are not immigrants; since the early twentieth century, they have been natural-born citizens. The complicated commonwealth status imposed on Puerto Rico by a trade between colonial powers (albeit a status Puerto Ricans now generally accept as a compromise between independence and statehood) justifies treating Puerto Ricans living on the island as a nation within the United States. Puerto Ricans living in the fifty states thus represent a kind of national subgroup with historically based claims to linguistic and cultural rights. ${ }^{107}$ And, as noted at the outset, the uniquely ongoing nature of present-day immigration serves to "refresh" the ethnic identities of minorities living in the United States, highlighting the artificiality of distinguishing between the types of minorities that make up cultural subcommunities in the United States. ${ }^{108}$

At the end of the day, the United States should move beyond the national minority paradigm because it privileges the less compelling justification for language-based claims, not because national minorities do, in fact, live within the boundaries of the nation. The value of language and culture to the individual can be articulated in universal terms, underscoring that the language-based claims of groups formed largely through recent migration have an inescapable legitimacy. Rethinking the national minority paradigm along these lines will help ensure that the concept of "language rights" remains capable of responding to the evolution of language groups, whether national minority or immigrant-based.

Conceptual Structures of Indigenous People's Claims in International and Comparative Law, 34 N.Y.U. J. INT'L L. \& POL. 189 (2001), the indigenous case powerfully underscores the validity of revival as a remedy. At the same time, however, the sui generis quality of the indigenous claim to language recognition based on a history of colonial dispossession highlights the limitations of the remedial justification. Precisely because remediation for a serious historical offense may well require the state to actively perpetuate a minority culture, emphasizing the remedial justification for language rights permits majorities to define the universe of legitimate language-based claims in terms of the unique case of severe repression, thereby ignoring the far larger set of language-based concerns that do not stem from a history of brutality. While the unique posture of indigenous populations' claims may well make a remedial and hence preservationist approach politically palatable in their context, the participatory conception laid out below offers an alternative way of thinking about language claims that is both more comprehensive and more appealing as a general matter.

107. Cf. Katzenbach v. Morgan, 384 U.S. 641 (1966) (upholding section 4(e) of Voting Rights Act of 1965 , which provides that no person who has completed sixth grade in Puerto Rican school where language of instruction was not English shall be denied right to vote because of inability to read or write English; provision was upheld even though federal statute prohibited enforcement of New York laws requiring ability to read and write English as a condition of voting).

108. See supra notes 21 and 23 . 
Moving in this universalistic direction need not mean that we must accord all language groups equal status in all circumstances, nor would it preclude declaring some groups' claims more compelling than others. It may well be that immigrants, as a group, have been and will continue to be less inclined to fight for the long-term survival of their cultural communities than national minorities. ${ }^{109}$ The strong assimilationist narrative according to which immigrants come to societies like the United States seeking cultural transformation may be based on a crude understanding of consent. ${ }^{110}$ But the sociological data describing the linguistic assimilation of immigrants discussed above suggests that we should take seriously a weaker version of the assimilation narrative. ${ }^{111}$ Indeed, the history of German immigrants, whose language and culture were once pervasive in the United States, ${ }^{112}$ demonstrates that the cultural issues associated with immigration work themselves out over two or three generations, whether we pursue an assimilationist or an accommodationist language policy. ${ }^{113}$

But even if immigrants are less likely to fight for cultural survival than national minorities, the language question in a society like the United States should not be seen as a purely transitional one. Steady immigration makes bilingualism a cross-generational social phenomenon by ensuring that the foreign-born and their immediate descendants will be present for the foreseeable future, even though a given family line may assimilate completely within three to four generations and become English dominant within only two. Efforts to address our present demography should not be skewed by the assumption that, in a century's time, Spanish or commonly spoken Asian languages will be as marginal in the United States as German is today.

Relying on the national minority paradigm to frame the issue of language rights results in a worldview where assimilation represents the only option for immigrants, because its opposite-self-government-is implausible. But this framework ignores the possibility that existing legal and social institutions can be transformed to create a public sphere that recognizes a variety of cultural identities. The proliferation of marketprovided services and media outlets in languages other than English across

109. Compare ALBA \& NEE, supra note 9, at 229 (documenting linguistic assimilation patterns of immigrants in United States) with supra notes 34-66 (discussing survival claims of national minorities in Spain, Latvia, and Canada).

110. See supra notes 79-84.

111. See Alba \& NEE, supra note 9, at 229.

112. See generally Heinz Kloss, The American Bilingual Tradition (1998).

113. See Robert Henry Billigmeier, Recent German Immigration to America, in ConTEMPORARY AMERICAN IMMIGRATION: INTERPRETIVE EsSAYs 110 (1982) ("Even though the German immigrants came in large numbers in most periods of American history, and though they often gathered themselves into at least loosely formed communities, their assimilation occurred relatively fast. The persistence of some aspects of their traditions, attachments, and sense of a special identity has not prevented the acquiring of the major pattems of American culture and identity."). 
the United States, and the spectacle of politicians scrambling to inject Spanish into campaign speeches, suggest that public culture can sustain varied linguistic turns - that it can, in fact, be linguistically transformed. In the end, the national minority paradigm simply cannot account for the variety of speech communities that any given multilingual society must govern, because the linguistic profiles of this country and others are more diverse than the national minority paradigm suggests.

\section{Final Thoughts on Remediation}

Both conceptions of language rights outlined in this Part will play an important role in any language rights discourse. Survivalism represents a necessary response to historical relationships and circumstances, and the transitional approach, supported by a general antidiscrimination imperative, will perform a useful integrative function in multilingual democracies, like the United States, that receive large-scale immigration. It may be that a combination of these two principles will be adequate for managing language-related conflict by giving the most vocal language minorities institutions of their own, protecting minorities within minorities through laws that prohibit deliberate forms of discrimination or oppression, and ensuring that language difference is not a permanent barrier to integration. But these remedial ideas, while necessary, are limited as organizational principles for a multilingual society.

The dominant, survivalist approach to language rights is limited by its inability to deal with the linguistic consequences of immigration. It results in an incomplete appreciation of the linguistic interests of immigrants in societies dominated by historical struggles between long-standing national minority groups. Indeed, it has little or nothing to offer on the subject of general bilingualism, as opposed to bilingualism in the state's official or dominant languages, which is a key issue in polyglot, immigrant societies such as the United States, Canada, or the European Union. Because it looks backward for its raison d'être, the remedial objective tends to ignore the emergence of new linguistic groups and the changing character of existing groups, and it does not account for the multilingualism that remains once the goals of survivalism have been achieved. A remedial principle focused on ensuring that language minorities acquire skills in the dominant language does not specify how an institution should respond to inescapable inultilingualism in its population that will nonetheless persist. What is unore, the basic claim that all people should be free from language-based discrimination assumes an essential connection between cultural identity and human dignity that calls for forms of affirmative recognition. The participatory approach I offer in Part II thus reorients language policy to account for the linguistic interests that fall outside the parameters of the various remedial rationales identified above. 
II

\section{Language and Participation}

It may make sense as a structural matter to think of language difference in terms of how it affects interactions among people, but why motivate people to participate at all? In my view, the experience of participation in a collective social endeavor has both social and personal benefits. Through interaction and cooperation with others, people become socially invested, because they acquire a sense of ownership over the institutions that govern their activities and a stake in the long-term viability of those institutions. ${ }^{114}$ Moreover, participation in civic life gives rise to a sense of control over one's destiny and the destiny of one's children by giving individuals voice in the institutions that inevitably shape that destiny. In framing participation in this manner, I take certain cues from theories of democracy that emphasize experimentation and collaboration. Under such frameworks, it is through organization and social action, or by thinking and working together, that the concept of individual autonomy acquires meaning, and self-realization becomes possible. ${ }^{115}$ Additionally, experimental forms of organization and active collaboration among social actors teach problem solving and therefore promote learning. ${ }^{116}$ In developing a participatory approach to language difference, then, I focus on how to motivate and facilitate participation in a manner that adds experimental and dynamic energy to institutions while leaving individuals with autonomy over matters of deep personal concern.

At first glance, encouraging participation might seem to require promotion of a common language for the sake of communication. After all, effective participation depends on many of the virtues that advocates of rapid linguistic assimilation extol; under their view, deliberation, the creation of a common political identity, and social mobility all depend on the possibility of communication in a common language. ${ }^{117}$ If we adopt this assumption, it might seem appropriate to emphasize the instrumental aspects of language and converge on a monolingual policy, rather than a

114. This sense of ownership stems from a feeling of "political efficacy" derived from the exercise of control-a concept that contemporary theorists trace to the theories of Rousseau and Mill. See generally Carole Pateman, Participation and Democratic Theory 22-35 (1970).

115. See, e.g., John Dewey, Renascent Liberalism, in John Dewey: The Political Writings 142, 148, 151-52 (Debra Morris \& lan Shapiro eds., 1993).

116. See, e.g., Michael C. Dorf \& Charles F. Sabel, A Constitution of Democratic Experimentalism, 98 Colum. L. Rev. 267, 283-89 (1999) (discussing a new model of democratic experimentalism, inspired by Dewey's pragmatism and designed to promote practical collahoration as a form of democratic action); see also James S. Liebman \& Charles Sabel, A Public Laboratory Dewey Barely Imagined: The Emerging Model of School Governance and Legal Reform, 28 N.Y.U. REv. L. \& Soc. ChANGE 183, 303 (2003) (discussing how new techniques and principles emerge from "problemsolving diversity").

117. Ronald Schmidt, Sr., Language Policy and Identity Politics in the United States $139-45$ (2000) (discussing debate over rapid assimilation policies). 
multilingual policy that takes account of the cultural value of particular mother tongues to individuals or social subgroups. Certainly scholars of language conflict have observed that the typical human response to the "Babel of languages" is to "carve out a space in which only 'our' language is spoken"118 in a quest for a homogeneity conducive to easy communication.

But the need for a multilingual account of participation, which seems counterintuitive at first glance, becomes obvious upon further analysis. To establish this claim, I begin from the premise that an adequate theory of democratic participation for a large and dizzyingly diverse society like the United States must be based on principles of decentralization. In taking this approach to participation, I contemplate not only decentralization according to a federalist design of some sort, but also the decentralization of our perspective from governmental institutions to the mid-level social and cultural institutions that structure most people's daily lives, such as the public schools and the workplace. ${ }^{119}$

Decentralization, in the first, federalist sense, represents a timehonored mechanism for channeling conflict and diversity of all types, as well as for enhancing the responsiveness of government to the concerns of the people. In a large, heterogeneous society, decentralization makes pragmatic sense, because it allows decision making about diversity to be maximally responsive to changing circumstances and preferences across the population. The popularity of culture-based devolution in other parts of the world and federalism in the United States both reflect this intuition. ${ }^{120}$

I carry the idea of decentralization an important step further by focusing on interaction in social institutions, rather than on participation at high levels of government. As theorists of participatory democracy explain, for democracy to thrive, participation must be understood broadly to include the sites of true social engagement. ${ }^{121}$ Participation in high-level national

118. Shell, supra note 30 , at 1 .

119. "[F]or a democratic polity to exist it is necessary for a participatory society to exist .... The most important area is industry; most individuals spend a great deal of their lifetime at work and the business of the workplace provides an education in the management of collective affairs that it is difficult to parallel elsewhere." PATEMAN, supra note 114, at 43; see also CyNThIa Estlund, Working Together: How WorkPlace Bonds Strengthen a Diverse Democracy (2003).

120. Even in the American context, a discussion of decentralization need not be limited by existing federal structures. In developing his theory of democratic experimentalism, Charles Sabel, in particular, argues that we need new ways of effecting decentralization's productive possibilities. His model depends on "linked systems of local and inter-local" collaboration, see Dorf \& Sabel, supra note 116, at 287. The model also envisions collaboration between citizens and agencies that avoids the limitations of both top-down and bottom-up decision making, see Liebman \& Sabel, supra note 116, at 191 (arguing that educational reform has succeeded where top-down and bottom-up decision making has been avoided), 271 (discussing collaboration).

121. "The theory of participatory democracy is built round the central assertion that individuals and their institutions cannot be considered in isolation from one another. The existence of representative institutions at the national level is not sufficient for democracy; for maximum 
institutions is not sufficient to produce a vital democracy. Because our lives are intimately intertwined with mid-level institutions, such as the workplace and the public schools, a political system that depends on the active engagement of the people must be concerned about the nature of participation in these types of places. The "authority structures" of midlevel institutions, therefore, should function as political systems organized to provide individuals with the "maximum amount of control over their own lives and environment." 122 Giving individuals this kind of control encourages them to engage with community affairs and to invest in public institutions and the people those institutions serve.

Once we frame our understanding of participation in this manner, multilingualism becomes an asset, not a threat, to effective participation. Respecting and promoting bilingualism in individuals and multilingualism in our institutions will improve the quality of communication and participation in those institutions. This improvement will emerge for instrumental as well as affective reasons. Instrumentally speaking, participation requires communication among social actors in at least three directions: (1) among individuals within the same linguistic subcommunities; (2) among individuals of different linguistic subcommunities; and (3) between subcommunities and the majority language community. As I explain below, bilingualism in individuals and multilingualism in society is what makes this varied communication possible. And as an affective matter, the process of weaving different linguistic groups into a political community requires recognition of the emotional associations with family, heritage, and community that give particular languages value to their speakers. ${ }^{123} \mathrm{~A}$ multilingual approach to participation, ultimately, addresses the practical implications of an inescapable demographic reality and provides a means of managing that reality while still maintaining respect for personal preferences.

The Canadian case helps illuminate why embracing linguistic diversity promotes participation. Despite being structured around a remedial paradigm focused on the interests of national minorities, the Canadian

participation by all the people at that level, socialisation, or 'social training', for democracy must take place in other spheres in order that the necessary individual attitudes and psychological qualities can be developed." Pateman, supra note 114, at 42; see also Cass R. Sunstein, Beyond the Republican Revival, 97 YALE L.J. 1539, 1573 (1988) ("Citizenship ...docs not occur solely through official organs. Many organizations-including labor unions, religious associations, women's groups of various sorts, civil rights organizations, volunteer and charitable groups, and others . . . serve as outlets for some of the principal functions of republican systems.").

122. Pateman, supra note 114 , at 43 .

123. Compare this to Alan Patten's discussion of language recognition, in which he identifies three distinct aspects of language: the interest in communication, the interest in symbolic affirmation, and the interest in identity promotion. See Patten, supra note 26, at 695. In my view, the latter two are both aspects of what 1 call the affective side of language, but 1 prefer to describe the affective dimension in terms of connection to family and community - an interest that may include but is not necessarily limited to symbolic affirmation or identity promotion. 
language rights regime draws as well from a participatory ethic. The language rights protected by the Charter of Rights and Freedoms of 1980 emerged from a long period of debate in the 1960s and ' 70 s over how best to elevate the status of Canadian Francophones, who were persistently underrepresented in public life and at the top of the socioeconomic ladder. ${ }^{124}$ Many of the language rights ultimately included in the Charter, as well as subsequent federal and provincial statutes, were intended to enhance Francophones' participation in the institutions of public and social life.

The principle of bilingual enactment, which requires that government enact all laws in both English and French, gave Francophones a sense of ownership over the law and the lawmaking process. ${ }^{125}$ The bilingualization of the federal bureaucracy promised to make government more accessible to Francophones generally and to ensure that Francophones had equal opportunity to participate in government work. The right to have one's children educated in one's mother tongue gave Francophones control over forms of decision making central to the transmission of their culture from one generation to the next. ${ }^{126}$ These and many other constitutional and statutory enactments recognized the fact of linguistic pluralism and attempted to impose a structure on law and social institutions that would keep Canada's two major language groups socially invested. ${ }^{127}$ In so doing, Canadian reform efforts also embodied a respect for people's personal attachments to language and culture, as well as a corresponding recognition that fostering participation requires acknowledgment of these attachments. ${ }^{128}$ Today, the guarantees provide a framework for fostering participation in Canadian public life by making government accessible to Anglophones and Francophones alike. ${ }^{129}$

124. See Silver, supra note 53, at 693 (discussing the underrepresentation of Francophoncs in public service).

125. See Constitution Act, 1867, U.K. 30 \& 31 Victoria, c. 3; see also Roderick A. MacDonald, Legal Bilingualism, 42 MCGILL L.J. 119, 145 (1997) (arguing that official bilingualism contemplates popular ownership over law by acknowlcdging that full "normativity" of law can be apprehcnded only "through 'committed practices' in both languages.").

126. See Part 1 of the Constitution Act, 1982, being Schedule B to the Canada Act 1982, ch. 11 (U.K.), § 23 (Can.).

127. See, e.g., R. v. Beaulac, [1999] 1 S.C.R. 768, 786-87 (Can.); see also Réaume, supra note 88, at $601-11$.

128. The same could bc said of language policies in the autonomous communities of Spain. The autonomous communitics have understood the goal of their language policies to be both the normalization of the minority language and the global use of that language. They have sought to structure a legal regime that revives the minority languages, protects them from the force of assimilation, and makes them viable as languages in public institutions. See RuBlo-MARín, supra note 39 , at 122 .

129. The Supreme Court of Canada has read the Charter's equal status principle to contain an aspirational element, according to which judges should intcrpret language rights in terms that contribute to the pursuit of de facto equal status. See Ass'n of Parents for Faimess in Educ. v. Societé des Acadiens du Nouveau-Brunswick, [1986] I S.C.R. 549, 554 (Can.). (Dickson, C.J., concurring). According to Canadian scholar André Braën, to serve their purpose language rights must provide "the 


\section{A. The Instrumental Case for Multilingualism}

The instrumental case for a multilingual account of participation begins with the decentralization premise. The decentralized perspective on participation steals force from the monolingualist's argument, because the relevant community is no longer a large, national, monolithic one. The linguistic spaces most relevant to a discussion of participation become the variety of public and social spaces that organize the lives of more discrete communities. ${ }^{130}$ Local and social institutions of course have communicative interests and are run, in part, through conversation. Linguistic commonality will be needed, particularly in places such as New York City, where the nation's linguistic diversity is replicated on a much smaller scale and therefore intensified. ${ }^{131}$ Yet the interest in communication is not a single, general interest, but rather a series of interests in different types of communication-communication among individuals within subcommunities, among individuals from different communities, and between subcommunities and the body politic more generally. The goal of a theory of participation must be to enable people to deliberate and travel in and among these different spheres of life. Given the coinplexity of the communicative interest, then, I focus on giving language communities the capacity to function in two ways: internally and within a larger social context. Understanding communication in this way will help guarantee that individuals have access to a multiplicity of associative options. ${ }^{132}$

\section{Multilingualism and Intergroup Communication}

For individuals who either do not speak English or maintain a strong preference for non-English, the existence of minority language communities is vital to their ability to associate with others. For those whose bilingualism tends toward preference for English, these subcommunities nonetheless represent a site with meaningful associative possibilities, either

opportunity of dealing on an equal basis with the majority as well as possessing appropriate means to conserve their linguistic specificity." André Braën, Language Rights, in Language Rights in CANAdA 8 (Michel Bastarache ed., 1987).

130. See Shell, supra note 30, at 2 (discussing the "range of linguistic spaces" and calling for academic discussion to look beyond the space of the nation state).

131. See generally New York City Department of Planning, supra note 12, at xi (noting that $36 \%$ of New York City's population in 2000 was forcign born, and that the foreign-born population has "extremely diverse origins"); $i d$. at I (noting that " $46 \%$ of the population speaks a language other than English at home," and that New York City has no dominant racial or ethnic groups).

132. This approach bears some resemblance to the Rawlsian strategy Alan Patten adopts in his liberal neutrality model: "The task of language policy is not to realize some specific linguistic outcome but to establish fair background conditions under which speakers of different languages can strive for the survival and success of their respectivc language communities." Alan Patten, Liberal Neutrality and Language Policy, 31 PHIL. \& Pub. Aff. 356, 366 (2003); cf. Patten, supra note 26, at 710 (discussing three different versions of equality relevant to language policy: cquality of resources to pursue one's intcrests; equality along some social intercst other than but still related to the language interest; and equality of success in promoting one's linguistic interests). 
because of family connections and personal networks, or in light of cultural preferences. The existence and regular use of certain non-English languages is essential to the well-being of these vital subgroups. Securing a broad range of associative options for people thus requires embracing English/non-English bilingualism in individuals and therefore accepting social multilingualism. Given that these subgroups exist and are important in a participatory sense, it becomes crucial to determine how to facilitate intergroup communication. We require resources for dealing with the absence of a universally common language-an absence that is inescapable in the United States and other diverse societies, whether or not we prefer monolingualism.

Making such communication possible ultimately depends on the development of bilingual agents. Through bilingual and multilingual participants, communication can occur across groups. Facilitating the complex communicative interests of a multilingual society thus requires acknowledging that human resources, in the form of individual bilinguals, are both necessary and worth developing. In other words, human resources in the form of members of subcommunities exist and can help bridge language barriers. Even the United States Supreme Court has recognized the potential of these resources: "Language permits an individual to express both a personal identity and membership in a community, and those who share a common language may interact in ways more intimate than those without this bond. Bilinguals, in a sense, inhabit two communities, and serve to bring them closer."'133

Promoting bilingualism in individuals thus simultaneously secures for individuals the linguistic means for social mobility and channels the bridging function bilinguals are uniquely suited to perform by using the lingua franca of English to link different subcommunities to one another and to a polyglot mainstream. Indeed, the value of the bridging function extends beyond our borders. The development of our linguistic capacities as a society will give the United States a competitive edge by connecting the country, through its people, to the rest of the world.

The affirmative development of bilingualism thus serves an integrationist vision, because it unites otherwise disconnected communities. ${ }^{134} \mathrm{By}$ contrast, the public demotion or exclusion of a language through restrictive official language laws and other means may well encourage language minorities to identify with their nondominant language, as opposed to with

133. Hernandez, 500 U.S. 352, 370 (1991) (upholding exclusion of bilingual individuals from jury).

134. What is more, the persistence of robust democratic cultures in multilingual nation-states such as Spain and Canada demonstrates that a functioning political culture does not require absolute mutual intelligibility among all participants. 
the society's dominant language. ${ }^{135}$ Sociolinguistic research has demonstrated that "intergroup grievances" can foster ethnic identity and language use. ${ }^{136}$ In light of this possibility, an aggressively monolingual national language policy in a multilingual nation may well undermine its own best intentions. In order to develop the bilingual agents required to facilitate intergroup communication, then, our preference should be for policies that enable identification with English and minority languages both.

But facilitating the multidirectional communication described above requires more than the development of bilingual agents. It also depends on the existence of bilingual institutions. Effective participation depends not just on facilitating communication among communities, but also on improving access to institutions by developing institutional capacity to include non-English speakers. Achieving this objective requires setting up the means for interaction, either by providing targeted interpretation, or by delivering services and conducting business directly in non-English-a process that depends, naturally, on the development of bilingual agents. Ensuring access also requires that we focus our attention on a broad range of institutions, such as the local department of motor vehicles, the city council, the public schools, and the state and federal courts, as well as social institutions, such as the workplace.

To be sure, the long-term consequences of a commitment to developing bilingual resources are hard to predict. In some cases, the commitment may lead to the complete assimilation of a group, and in others to the survival of certain subgroups. In the medium term, however, it will facilitate, not impede, interaction among society's various social and cultural entities. Commitment to bilingualism acknowledges the instrumental and cultural value of the dominant language to speakers of minority languages. At the same time, it acknowledges that rapid assimilation results in the loss of important cultural assets. ${ }^{137}$ Bilingual ability, if embraced, will amplify the expressive capacities of both the individual and the political community.

135. See Joshua A. Fishman, Sociolinguistics, in Handbook of Language and EThNic IDENTITy 152, 154, 161 (Joshua A. Fishman ed., 1999).

136. Mark Janse, Introduction: Language Death and Language Maintenance: Problems and Prospects, in Language Death and Language Maintenance, at x (Mark Janse \& Sijmen Tol eds., 2003) ("As much as linguicide and linguistic discrimination may add to language death, they are at the same time powerful forces in the reawakening of ethnic identity feelings among speakers of endangered minority languages.... Ethnic identity is often accompanied by an increased interest in language maintenance.”).

137. See, e.g., Edward M. Chen, Staff Counsel, American Civil Liberties Union of Northem California, Statement Before the U.S. House of Representatives, Subcommittee on Early Childhood, Youth, and Families (Nov. 1, 1995) ("America's own history dispels the notion that an 'official" language is needed to preserve national unity."). 


\section{The Instrumental Value of Linguistic Conflict}

While a decentralized perspective on participation helps make a multilingual public life seem manageable, the presence of multiple language groups within local and social institutions will nonetheless give rise to language conflict. Even in a decentralized world, the claims can be made that cultural homogeneity is necessary to maintain stability and that popular forms of government require people to organize themselves around $a$ common language and culture. These claims, however, overlook several important realities.

As a sociological matter, while multiethnic societies may be inherently less stable than homogeneous ones, ${ }^{138}$ a homogeneous United States would be nearly impossible to achieve in light of immigration patterns. These patterns underscore that even a restrictive immigration law designed to increase our cultural hoinogeneity would not alleviate the pressure exerted by the market forces that propel immigration. ${ }^{139}$ One way to regard language conflict, then, is as inevitable in a multiethnic society. Because monolingualism is not an achievable goal from a demographic perspective, we would be wise to develop the bridging capacity of bilingual agents and the linguistic capacity of institutions to help ameliorate the inevitable conflict.

But linguistic diversity is not just inevitable. It is arguably the only acceptable alternative in a liberal democracy. The social and personal costs of the forced assimilation required to homogenize the populationcurtailing personal autonomy, threatening social isolation, creating culturebased inequalities - would be anathema to basic liberal democratic principles. Perhaps more importantly, linguistic diversity can be instrumentally valuable in an affirmative sense. Heterogeneity and diversity are crucial to a political systein based on progress through the exchange of ideas, and recognition of their value should always temper appeals to the value of stability.

The idea that democracy thrives on difference is not a new one. As a general matter, theorists who take the kind of pragmatic approach to

138. See Adam Przeworski et al., Culture and Democracy, in The Democracy Sourcebook 187, 188-89 (Robert A. Dahl et al. eds., 2003). ("Ethnolinguistic fractionalization makes democracies less likely to survive: this much confirms common wisdom. But when the colonial legacy of a country is considered, it makes dictatorships less likely to survive as well. Hence, it seems that ethnolinguistic heterogeneity just makes political regimes less stable and, indeed, its effects on both regimes vanish when controlled for past political instability.").

139. See Walter A. Ewing, Symposium: Globalization, Security \& Human Rights: Immigration in the 2Ist Century: From Denial to Acceptance: Effectively Regulating Immigration to the U.S., 16 StaN. L. \& POL'Y REv. 445, 446 (2005) ("Fruitless efforts by the U.S. government to stem the migratory flows produced by its own economic policies and demanded by the U.S. labor market have simply driven a large share of immigration to the United States underground and swelled the ranks of the undocumented."); see also Portes \& Böröcz, supra note 79 (discussing reasons for migration that are largely external to the law). 
democracy outlined above emphasize the value of bringing inevitably conflicting interests "out into the open," where they can be settled with "the interest of the widest possible contribution to the interests of all."140 Though diversity may seem to add intractable complexity to social life, confronting that diversity in our interactions is ultimately what will make dealing with the pressures of diversity possible. ${ }^{141}$ What is more, multiplicity in a society forces one to notice that one's own practices-one's religion, language, and cultural values-are not the only means for living a "legitimate" life. ${ }^{142}$ This awareness has instrumental value for individuals, because it can inspire the examination of one's own practices and customs, ${ }^{143}$ thus promoting self-improvement. It also has instrumental value for the larger social order, because it promotes tolerance and learning. Language diversity is likely to be particularly productive of this valueenhancing conflict, because the difference that it announces is immediately obvious to the hearer. Language diversity leads to immediate and challenging confrontation with the unknown.

Under this formulation, politics concerns more than identifying and proceeding from our points of commonality. It is also about learning to deal with the strange or unknown through productive embrace, rather than by destabilizing attempts at suppression. ${ }^{144}$ Indeed, some theorists who define democracy in pragmatic terms deemphasize the elusive common good in favor of a conception concerned with negotiating power relations to avoid the domination of one group by others. ${ }^{145}$ Legal rules and public policies designed to resist the drive toward homogenization and to make use of the sources of the unknown thus take on a democracy-enhancing character. Such rules will help preserve the value-enhancing diversity inherent in a plural society - a value premised on the fact that the cultural mainstream, in reality, will always be a moving target. ${ }^{146}$

The Supreme Court's recent reorientation of affirmative action jurisprudence highlights the notion that diversity can play a positive role in American social life. ${ }^{147}$ To justify affirmative action policies in the educational context, the Court has shifted from a backward-looking inquiry into

140. See Dewey, supra note 115 , at 148 .

141. See Dorf \& Sabel, supra note 116, at 285-86 (discussing how, to early Pragmatists, confronting difference was "central to self- and mutual understanding").

142. See Doris Sommer, Bilingual Aesthetics: A New Sentimental. Education 93 (2004).

143. See id.

144. See id. at 84 (citing Bonnie Honig, Democracy and the Foreigner (1999)).

145. See Ian Shapiro, The State of Democratic Theory 3-5 (2003).

146. See ALBA \& NEE, supra note 9, at 11-14 (discussing the theory of assimilation according to which immigration transforms the dominant culture, even as immigrants and their descendants evolve linguistically and culturally).

147. The Supreme Court's decision in Grutter $v$. Bollinger confirmed that legal and political consciousness of racial and cultural diversity legitimize social institutions and encourage broad-based participation in those institutions. See 539 U.S. 306, 331-32 (2003). 
historical subordination to an aspirational embrace of diversity, emphasizing that diversity in institutions helps secure their legitimacy in the eyes of all people. Not only does culture-based diversity enhance the vitality of institutions by injecting human sources of productive debate and conflict, it also operates as a check on their fairness in light of the fact that they govern the many groups that constitute the body politic. As states and localities check the power of the central government, diversity as a value empowers the people to check institutions by ensuring that neither power nor identity is concentrated in the hands of a single group.

Finally, and relatedly, permitting language conflict to manifest itself, rather than trying to suppress it through enforced monolingualism, will likely reduce conflict in the long run, because it will promote a fair allocation of cultural burdens among citizens. On the one hand, we could regard English-only rules as understandable and appropriate attempts by the majority in the United States to secure control over its own cultural destinyto resist its own assimilation into a multilingual mainstream. In reality, however, English-only rules place the burden of linguistic diversity almost entirely on the shoulders of the linguistic minorities who must assimilate. They excuse the English-speaking majority from meaningfully participating in the negotiation of societal multilingualism.

A multilingual account of participation, in contrast, spreads the burden of linguistic diversity around the population by expecting all people to tolerate conversations they cannot understand and to struggle with the inability to communicate. The inverse of the reasonable American expectation that immigrants learn English is the reasonable social expectation that non-immigrants bear certain cultural responsibilities of their own. These responsibilities will include accepting linguistically diverse public spaces. Requiring this form of acceptance might mean that monolingual English speakers will not understand every conversation had in the public sphere. Lack of knowledge of another language or culture might translate into disadvantage in, say, the labor market. Multilingualism could create economic and humanistic incentives for native English speakers to learn something about minority languages and cultures, imposing a kind of obligation on the former to engage a cultural world outside their own. But as social trends change, so should the expectations of native English speakers. A multilingual account therefore promotes a kind of cultural fairness by making majority and minority alike responsible for absorbing the cultural consequences of immigration and globalization, and for adjusting to the presence of one another.

\section{B. The Affective Case for Multilingualism}

In addition to promising the benefits described above, a multilingual account of participation in our important public and social institutions is 
more consistent with the aspirations of participatory democracy than a monolingual account for what I call "affective" reasons. By recognizing citizenship's cultural dimension, an approach to participation that strives to recognize and harness multilingualism will inspire loyalty and willingness to participate. A system that integrates linguistic diversity into its institutions will more likely give individuals the sense of control over personal cultural destiny they typically crave than will an approach bent on ridding institutions of this potential source of cacophony.

\section{The Affective Value of Cultural Recognition}

Strict state neutrality with respect to the cultural identities of its people is not widely endorsed, perhaps because of the general impossibility of achieving it, particularly in the case of language. ${ }^{148}$ The multicultural version of liberal theory ${ }^{19}$ builds on this reality and demonstrates why liberal rights should be interpreted as having cultural content. By publicly recognizing its people's cultural identities, the state acknowledges that culture plays a role in creating the preconditions for a participatory democracy by giving individuals certain goods necessary to individual freedom. ${ }^{150}$ First, culture gives individuals a "context of choice," which promotes freedom by giving people a broad range of options for how to live their lives. ${ }^{151}$ As

148. See Patten, Liberal Neutrality and Language Policy, supra note 132, at 356 (quoting Kymlicka's argument that "[t]he idea that government could be neutral with respect to ethnic and national groups ... is patently false").

149. The multicultural explosion of the 1990s gave rise to a variety of multicultural projects and political movements, ranging from relatively innocuous celebrations of diversity, to politically heated debates over campus speech codes, to the call for ethnic studies in universities. See generally BEYOND COMFort Zones in Multiculturalism (Sandra Jackson \& José Solís eds., 2003) (discussing various programmatic aspects of the multiculturalism movement). Multicultural theory is not synonymous with any one of the multicultural programs of this period. Rather, multicultural theory represents an exploration of how modem understandings of democratic government and politics are affected by and should be re-imagined to account for our world's increasing heterogeneity. Multiculturalism's fundamental questions include how equality, freedom, and political autonomy relate to one another and can be realized best in a pluralistic world. Multicultural theorists identify culture as a critical axis in this inquiry. Their theoretical concerns are central to a number of political projects, including the development of transnational institutions and human rights law, nation-building enterprises, and the constitutional development of stable democratic regimes in multiethnic nation-states. See generally KYMLICKA, supra note 77; KYMLICKA, supra note 26.

150. Many proponents of cultural recognition contend that we need not abandon individual rightsbased liberalism in order to account for difference. Habermas, for example, argues that the theory assumes that differences will be recognized because liberalism focuses on the protection of "the integrity of the individual in the life contexts in which his or her identity is formed." Jürgen Habermas, Struggles for Recognition in the Democratic Constitutional State, in Multiculturalism, 107, 113 (Charlcs Taylor ed., 1994). Rights are realized only intersubjectively, through "social movements and political struggles." Id.

151. KYML1CKA, supra note 26 , at $82-83$ (discussing Dworkin on culture). In Kymlicka's formulation, having meaningful options to choose from in living one's life depends on having access to one's societal culture, and on understanding the "language and history which constitute [the] vocabulary" of culture. Id. at 83 . Kymlicka defines societal culture as a culture that "provides its members with meaningful ways of life across the full range of human activities, including social, 
Canadian theorist Charles Taylor explains, we derive the ability to communicate, or the tools of self-understanding, through our interactions with others, ${ }^{152}$ a dialogic process that underscores the significance of the cultures around us to human development. Second, and perhaps more importantly, cultures provide their members with a sense of belonging. ${ }^{153}$ Participation in a culture can offer individuals a sense of social security, or a sense of being connected through practices and traditions to family, friends, and a community that transcends the here and now. This security then translates into a sense of self-respect that gives meaning to one's life choices. ${ }^{154}$ For these reasons, the individual's ability to thrive ${ }^{155}$ depends on public acknowledgment of his cultural contexts. ${ }^{156}$

Groups seeking recognition are not, of course, simply seeking symbolic affirmation of their cultures. They also seek status and power. I consider in the next Section the different forms this status or power might take. The point to recognize here, however, is simply that the goods groups of people typically seek-respect for their ways of life and the power to live life on their own terms--will require some form of public recognition of their cultures. This acknowledgment is essential in a democratic society that values equality as a form of mutual respect. ${ }^{157}$

\section{Cultural Recognition and the Coercion Critique}

The idea of cultural recognition cuts across the gram of several lines of thought influential in American legal culture. It challenges the strictly ncutral view that would leave regard for culture to the sphere of private choices and associations. ${ }^{158}$ As Charles Taylor acknowledges, recognition

educational, religious, recreational, and economic life, encompassing both public and private spheres," id. at 76, suggesting that the public sphere's failure to incorporate societal culture in some form should be cause for concern.

152. Charles Taylor, The Politics of Recognition, in Multiculturalism 25, 32-33 (Charles Taylor ed., 1994).

153. See Margalit \& Raz, supra note 104 , at $84-85$ (stating that the security that comes from being a member of a cultural group is a matter of belonging rather than achievement).

154. Taylor, supra note 152, at 41 .

155. Taylor credits Hegel with seeing recognition as fundamental to human flourishing and concluding that "the struggle for recognition can find only one satisfactory solution ... a regime of reciprocal recognition of equals." $I d$. at 50 .

156. See id;; see also lris Marion Young, Together in Difference: Transforming the Logic of Group Political Conflict, in THE Rights of Minority Cultures 162-63 (Will Kymlicka ed., 1995) ("Many people who are oppressed or disadvantaged because of their group identity nevertheless find significant sources of personal friendship, social solidarity, and aesthetic satisfaction in their groupbased affinities and cultural life.").

157. Gutmann, supra note 99, at 24 ("Mutual respect requires a widespread willingness and ability to articulate disagreements, to defend them before people with whom we disagree, to discern the difference between respectable and disrespectable disagreement, and to be open to changing our own minds when faced with well-reasoned criticism.").

158. See id. at 4; see also Anne Phillips, Democracy and Difference: Some Problems for Feminist Theory, in The Rights of Minority Cultures 288, 292 (Will Kymlicka ed., 1995). ("Liberals believe that people can (and should) detach themselves from whatever traditions or values they have 
challenges "the politics of equal respect []enshrined in a liberalism of rights" that is "suspicious of collective goals." 159 Recognition also is in tension with theories of cosmopolitanism, according to which human beings derive meaning not just from their inherited cultures, but also from the many cultural sources available in a pluralistic society, including the networks that "transcend national and ethnic boundaries," such as the "scientific community" or the "human rights community." 60 Critics of culture-based politics insist that ethnic identities represent "voluntary associations," without boundaries, shading off into a residual mass of people who think of themselves simply as Americans ... [with] no way for the various groups to prevent or regulate individual crossings."162 Finally, recognition strains against the prevailing colorblind conception of American civil rights law. American civil rights discourse long has focused on whether differences among citizens must be recognized or ignored to achieve equality, ${ }^{163}$ and the prevailing view holds that we are more likely to treat minorities equally by ignoring their minority status, not by "giv[ing] acknowledgment and status to something that is not universally shared."164

Each of these forms of opposition to a culture-based politics has varied sources and motivations, to be sure. But they all share an important concern-a general fear of coercion, or the worry that using the law to recognize cultural identity might result in policies that coerce individuals into identifying with particular subgroups. The danger of such coercion is at least twofold. Coercion threatens to isolate and insulate subgroups from the forces of change, ${ }^{165}$ and it results in the essentialization of minority identity, or the failure to treat individuals as complex, whole people. To some, Quebec's policy requiring both ethnically Francophone and immigrant parents to send their children to French-language schools, leaving

inherited."). But see Kukathas, supra note 101, at 230. ("[L]iberalism puts concern for minorities at the forefront. Its very emphasis on individual rights ... bespeaks . . wariness of the power of the majority over minorities. There is thus no need to look for alternatives to liberalism or to jettison the individualism that lies at its heart.")

159. Taylor, supra note 152 , at 60 .

160. Jeremy Waldron, Minority Cultures and the Cosmopolitan Alternative, in THE RIGHTS OF Minority Cultures 93, 102 (Will Kymlicka ed., 1995).

161. Michael Walzer, Pluralism: A Political Perspective, in The Rights of Minority Cultures 139, 149 (Will Kymlicka ed., 1995).

162. Id. at 150 .

163. See generally Tomiko Brown-Nagin, Elites, Social Movements, and the Law: The Case of Affirmative Action, 105 CoLum. L. REv. 1436 (2005).

164. Taylor, supra note 152 , at 39.

165. Waldron, supra note 160, at 109-10 (discussing how efforts to preserve a culture undermine the natural tendency of cultures to "live and grow, change and sometimes wither away"). 
English-language schools to the children of Anglophones exclusively, exemplifies these dangers. ${ }^{166}$

Though Quebec's language education policy may cross the line from freedom-enhancing to coercive, the possibility of such coercion should not stop us from developing a conception of cultural citizenship compatible with liberal democratic principles, for the simple reason that group identities matter to individuals. As late twentieth-century trends have demonstrated, cultural groups do not want to transcend their cultural traditions. Instead, they have clamored to "maintain themselves... living and working in their own languages, even as they modernize and liberalize their historical cultures." 167 Though people may learn from and appreciate multiple cultures, they remain tied linguistically and behaviorally to particular cultures. ${ }^{168}$ Just because groups exert influence over one another's members through social and political interaction does not mean that those groups cease to be salient, or that they can no longer be identified and described. Even where boundaries between cultural communities are loose, clearly definable ethnic communities and linguistic interests still exist. ${ }^{169}$

Because individuals find satisfaction in their group identities, groups can be regarded as legitimate political actors in a system that nonetheless values individual autonomy. Various theorists have underscored that we can deal in terms of group identity without trapping individuals in group dynamics they would prefer to abandon. In his recent work, for example, Kenji Yoshino holds open the possibility of appreciating "correlations between certain behaviors and certain identities... without falling into stereotyping" 170 as part of the attempt to assess and resist the assimilationist

166. See, e.g., Gutierrez v. Mun. Ct., 861 F.2d 1187, 1192-93 (9th Cir. 1988) (Kozinski, J., dissenting) ("The question of what authority an employer has to address language-related tensions in the workplace is one of exceptional importance. As sad experience elsewherc has shown, language can be a potent source of racial and ethnic discrimination .... In Canada, for example, the bitter mutual resistance of French- and English-speaking citizens toward one another's language has taken on the characteristics of a racial confrontation.... Although the United States has become the home for people from all parts of the world, we have been spared much of the language-related agonies elsewhere. A nation of immigrants, we have been willing to embracc English as our public language, preserving native tongues and dialects for private and family occasions.").

167. KYMLICKA, supra note 77, at 207.

168. Kymlieka cites Condorcet as the progenitor of modern cosmopolitanism; under Condorcet's view, cultural membership eventually would become optional and people would be liberated from "traditional identities," resulting ultimately in the emergence of a universal language. Id. at 203. He points out that nineteenth-century cosmopolitans believed national groups would be absorbed into increasingly larger entities as long as thcir individual rights were respected-a prediction proven either wrong or extraordinarily premature by the age of nationalism. Though, according to Kymlicka, a common civilization - a "modern, urban, secular, consumerist ... democratic civilization"-has emerged, distinct cultural identities have survived alongside it. See id. at 205-07.

169. See, e.g., id. at 209 (commenting on minority nationalism in Quebec, Catalonia, Flanders, Scotland, and Puerto Rico).

170. Kenji Yoshino, Covering, 111 YaLE L.J. 769, 782 (2002). Yoshino acknowlcdges that the antidiscrimination paradigm that protects behavioral traits, in addition to statuses such as race, poses a 
demands of law and related institutions. In her discussions of the logic of group conflict, Iris Young recognizes the possibility of understanding group identity in terms of complex, overlapping affiliations. ${ }^{171}$ She suggests treating intergroup dynamics in terms of a relational logic according to which groups are understood not as entirely distinct, but as overlapping or constituted in relation to one another; they thus shift their attributes and needs in accordance with salient relations. ${ }^{172}$ This relational logic suggests that the mainstream into which individuals might gradually assimilate is not static. Cultural identities constantly reinforce one another through social interaction, even as they provoke each other to evolve.

As others have framed it, in slightly stronger terms, "Membership is a matter of belonging, not of achievement ... Qualification for membership is usually determined by nonvoluntary criteria." 173 More often than not, one's mother tongue, like race or ethnicity, is determined by birth and is not a matter of "individual conscience." 174 While one can belong to more than one group or develop new cultural affiliations over time, most people are unlikely to escape completely the affiliations that, through home and school, have shaped them. Culture and language are not so accessible that we can adopt cultural practices we have neither inherited nor inhabited, transforming ourselves at will into members of a different culture. In the end, group membership ties individuals to their families and to a set of shared practices, values, and histories-to a comprehensive human narrative that simultaneously embraces and subsumes differences among individuals. ${ }^{175}$ These realities make the recognition of inherited identities

danger of essentialization. He argues persuasively, however, that the over-formalization of categories poses a greater danger to the protection of people from discrimination. See id. at 933.

171. Young, supra note 156, at 155, 161. In this essay, Young leverages her observations on the fluidity of group identity to criticize the tendency toward "Constitutional Nationalism" in Eastern Europe in the early 1990 s, according to which national identity was defined in terms of "bounded, determinate structures of language, belief, religion, [and] practice." Id. at 168. Such observations about the fluidity of culture are particularly apt in the U.S. context and should inform the way we approach the language debate in this country.

172. Id. at 162-66.

173. Margalit \& Raz, supra note 104, at 84.

174. Nathan Glazer, Individual Rights Against Group Rights, in THE RIGHTS of Minority Cultures 123, 126 (Will Kymlicka ed., 1995).

175. K. Anthony Appiah puzzles over whether it makes sense to prioritize cultural traits over other characteristics, such as personality traits, that are equally important to many individuals. Appiah answers his own question by emphasizing that the large, collective identities at the heart of these discussions of recognition provide "scripts," or "narratives that people can use in shaping their life plans and in telling their life stories." K. Anthony Appiah, Identity, Authenticity, Survival: Multicultural Societies and Social Reproduction, in MulticulturalisM 149, 160 (Charles Taylor, ed. 1994). In addition, he explains that the history of the Western world in general, and the United States in particular, can be told in terms of the mistreatment of groups. See id. at 160-62. Such mistreatment can be remedied only by acknowledging that membership in those groups is a valuable part of an individual's identity. See id. at 160-62. Recognition of cultural difference thus becomes a critical feature of equal treatment, though, as Appiah emphasizes, even when more benign scripts 
inescapably important. ${ }^{176}$ Given these insights, if we truly aspire to provide individuals both with meaningful opportunities to control their destinies and to enjoy a sense of belonging, we cannot ignore how the structures of public life influence culture and cultural subgroups.

\section{Language and the Project of Recognition}

The act of incorporating cultural identity into political and legal decisionmaking raises a basic definitional difficulty: which cultural practices should we recognize? ${ }^{177}$ One of the limitations of multicultural theory is its lack of specificity about what cultural recognition entails. Charles Taylor provides a partial answer to the question, arguing that not all cultural expressions deserve equal treatment: recognition of the equal worth of all people need not translate into state endorsement of all cultural practices or values. ${ }^{178}$ Acknowledging diverse cultural practices as a means of recognizing equal worth cannot require that we decline to prioritize and thereby judge those practices by acknowledging some and not others. ${ }^{179}$

In my view, language offers the ideal focal point on which to center the project of recognition. Relying on language rights adds a critical affective dimension into participatory politics, while also sidestepping the coercion concern expressed by skeptics of the politics of recognition, for two interrelated reasons. Language is sufficiently valuable to individuals, or sufficiently "thick," to perform the affective work described above. At the same time, it is sufficiently flexible, or sufficiently "thin," to avoid the coercion danger. Because the attachment to a language need not correspond to the affirmation of particular values, and because bilingualism is possible, a public sphere that embraces the existence of many languages will be a place where people remain able to interact and strive for values-based consensus.

The "thick" quality of language stems from its comprehensive character, by which I mean that language serves as both the source of and the medium for our expressive capacities. A speaker uses a particular language

replace negative ones, the danger that culture-based identification will limit the individual's horizons remains. See id. at 162-63.

176. As Kymlicka describes the upshot of cosmopolitanism, "[its] cultural mélange ... does not involve moving between societal cultures. It is simply a case of enjoying opportunities provided by the pluralistic societal culture." KYMLICKA, supra note 77, at 211.

177. Cf. Yoshino, supra note 170, at 937 (noting in his elaboration of a trait-based approach to antidiscrimination protections that, while the decision of which traits to protect may be debatable, it is crucial that a conversation concerning this decision take place).

178. Taylor also points out that a culture proper, or a "major culture," can be distinguished from a "partial cultural milieu[l within a society, as well as [from] short phases of a major culture." Taylor, supra note 152, at 66.

179. See Susan Wolf, Comment, in Multiculturalism 75, 78 (Charles Taylor, ed. 1994). "[T]he demand that all cultures and the works they produce be evaluated as equally good is intertwined with a repudiation of all possible standards for evaluation, which would undermine the validity of judgments of equal worth as much as it undermines judgments of inferior worth."). 
"to make statements about who she is, what her group loyalties are, how she perceives her relationship to her hearer, and what sort of speech event she considers herself to be engaged in." ${ }^{180}$ Language mediates the collective and personal dimensions of individual identity. The recognition of linguistic difference, therefore, acknowledges individuals' cultural pedigrees and respects the framework through which they define and situate themselves in different social contexts, or how they choose to relate with others.

Language is also comprehensive in the sense that it represents more than just a marker or symbol of culture; it is "the recorder of paternity, the expresser of patrimony and the carrier of phenomenology."181 Sociolinguists describe language as carrying "cultural content."182 A cultural community's loss of its common language often presages an impoverishing of its culture, because language operates as a repository of cultural meaning. ${ }^{183}$ Cultural vitality therefore depends heavily on language maintenance. Language is comprehensive because it has the capacity to record the full range of values held by the members of a cultural community.

In addition to having this deep relationship to cultural identity, language offers the ideal focal point for a politics of recognition because it is also comprehensive in a "thin" sense. All languages possess the ability to develop new words and concepts as the needs arise and thus represent frameworks capable of adapting to changing circumstances. ${ }^{184}$ What is more, as a cultural characteristic, language encompasses nearly all meinbers of a group, regardless of the individual member's beliefs or attachments to other cultural practices. Unlike other cultural traits, such as ethical or moral values, or even preferences for food, hairstyles, and fashion, members of a given cultural group almost universally share a connection to a language. The speaking of a language does not demand adherence to particular values, but rather provides the framework for expressing variation in other cultural forms.

Given these characteristics, then, a system of culture-based politics focused on language avoids the essentialization of minority identity. Using language as the mechanism of recognition avoids stereotyping, because

180. See Ralph Fasold, The Sociolinguistics of Society, at ix (1984).

181. Joshua A. Fishman, Language and Ethnicity, in LANGUAGE, ETHNiCity AND 1NTERgroup Relations 15, 25 (Howard Giles ed., 1977).

182. Nancy C. Dorian, Linguistic and Ethnographic Fieldwork, in HANDBOoK OF LANGUAGE AND Ethnic Identity 25, 31 (Joshua A. Fishman ed., 1999).

183. See David Crystal, Language Death 36-43 (2000); Ken Hale, On Endangered Languages and the Importance of Linguistic Diversity, in ENDANGERED LANGUAGES: LANGUAGE Loss AND COMmunity ReSPONSE 192, 204-12 (Lenore A. Grenoble \& Lindsay J. Whaley eds., 1998).

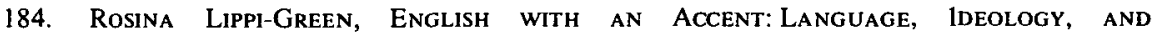
Discrimination in the United States 11 (1997); see also Joel Davis, Mother Tongue: How Humans Create Language 14 (1994) ("[L]anguages change. New words enter a language; new technologies generate new vocabularies; social or economic changes generate new patterns of discourse; sounds shift about."). 
acknowledging a language does not require specifying which values or customs an individual should adopt. Such an approach ensures that the recognizing state or institution does not impose upon individuals expectations that they conform to a group identity defined by a certain set of traits. ${ }^{185}$ Language-based rights or policies, by focusing on the organizational and expressive dimensions of culture, will result in an institutional recognition of culture that leaves conflict over value-laden worldviews to group members. Such policies avoid lending the imprimatur of the law to particular cultural practices, some of which may be contrary to liberal principles.

But perhaps most importantly, the recognition of language difference does not preclude individuals from developing a bilingual or bicultural orientation as a means of integrating themselves into a larger nation or world. That both people and communities have the capacity to be bilingual reinforces the value of language in this "thin" sense. The individual and social ability to be bilingual ensures that different language communities will be able to interact in the institutions common to all. ${ }^{186}$ Indeed, universal acquisition of English in the United States and of other widely spoken Ianguages in societies containing small Ianguage minorities is inescapably valuable, because it works against the tendency toward social division along ethnic and linguistic lines. Even as small languages increasingly become the media for local political, governmental, and economic activity, certain "megalanguages," especially English, Spanish, French, German, Japanese, Chinese, and Arabic, continue their spread, largely to good effect. ${ }^{187}$ The possibility of bilingualism makes language particularly valuable to those who are interested in simultaneously harnessing the value of ascriptive differences and promoting social integration. Approaching language difference in this way should make institutions accessible and relevant to minorities and, at the same time, institutionalize a form of resistance to the self-segregation that might prevent groups from evolving.

\section{Language and the Argument for Survival}

Relying on language to develop a project of recognition is not without its downsides. Other dimensions of ethnic identity often outlast the ability

185. Cf. Appiah, supra note 175 , at $162-63$ (discussing the possibility that recognizing group identities might constrain individual autonomy).

186. The fact that so many legal systems around the world have incorporated linguistically defined rights of some kind into their constitutional and statutory laws suggests that recognition of multilingualism serves a considered purpose. Indeed, various systems have developed a conception of language rights distinct from the protection of cultural rights more generally. A strain of thought running through Canadian case law and commentary suggests that cultural recognition and language recognition constitute two distinct enterprises. See, e.g., Choudhry, supra note 102 (noting this distinction but challenging its plausibility). While this distinction blurs very easily, the attempt to make it suggests that the actors involved-courts, lawmakers, and those seeking recognition of their linguistic interests-attach a special or particular significance to language.

187. See Fishman, supra note 135 , at 161 . 
to speak a common language, suggesting that linguistic recognition is not a complete answer to the questions that cultural difference raises. ${ }^{188}$ More significantly, a language-based form of recognition that emphasizes the possibility of bilingualism arguably encourages this assimilation. To the extent that language minorities prioritize the learning of the dominant languages of their societies, the likelihood of continued facility with minority languages diminishes, and the possibility that minority language communities will disappear remains unavoidable. But neither a politics of recognition centered on language, nor a participatory conception of a multilingual society, should adopt the survival of particular language groups as a primary goal.

Of course, when cultures face extinction, a compelling case can be made for their rejuvenation and perpetuation. ${ }^{189}$ Calls for revival may reflect guilt on the part of the dominant culture, which likely had a hand in the minority's near extinction. But survivalist clams also suggest a belief in the aesthetic and intellectual value of human heterogeneity. In the United

188. Indeed, in the Western provinces of Canada, French ethnic affiliation has outlasted the assimilation of many Francophones into an English-speaking world, much as ethnic communities persist in the United States despite the transformation of their non-English Ianguages from comprehensive systems of communication to sources of idioms and expressions of emphasis- to cultural "traits," so to speak. For a discussion of language shift among Francophone Canadians outside Quebec, see John de Vries, Canada's Official Language Communities: An Overview of the Current Demolinguistic Situation, I05/I06 INT'L J. of Soc. OF LANGUAGE 37, $62-64$ (I994); see also Richard Julien, The Quest for All-French Schools in Alberta: A Quixotic Struggle?, 25 Canadian Ethnic STUD. 25 (1993) (discussing attempts to reverse linguistic assimilation through creation of French Ianguage schooIs, and suggesting that group affiliation remains, despite linguistic assimilation). For an example of ethnic identification that has survived linguistic assimilation in the United States, see $O$. Garcia, J.L. Morin \& K. Rivera, How Threatened Is the Spanish of New York Puerto Ricans?, in CAN Threatened Languages be Saved? 44, 44 (Joshua A. Fishman ed., 2001) (describing the decline of Spanish Ianguage use among Puerto Ricans in New York as a primary mode of communication but documenting its use for symbolic purposes).

One consequence of resistance to linguistic assimilation is that a politics focused on language may result in the more linguistically sophisticated members of a group challenging the authenticity of those who have lost the ability to speak the language. Consider the Spanish-language debate in the 2000 Democratic gubernatorial primary in Texas. When one candidate insisted on providing English answers to questions posed in Spanish, the other candidate charged that his opponent's Spanish was inadequate - a fraught and potentially divisive charge in a language community made up of speakers of widely varying abilities. See, e.g., Sheila McNulty, Democratic Rivals for Texas Governor Talk it Out in Spanish: Bilingual Debate Reveals Growing Political Influence of Latinos, FIN. TIMEs, Mar. I2, 2002, at 13; R.G. Ratcliffe, Democrats Divided Further Over Debate: Sanchez Criticizes Morales For Planning to Use English During Spanish Segment, Hous. Chron., Mar. I, 2002, at A I.

189. The decline of language use among ethnic minorities raises the related interest in reversing language shift, or language revival. Reviving formerly oppressed or unused languages has been a successful phenomenon in parts of the world, including Spain and Israel, and it provides hope for indigenous populations seeking to recapture lost cultural origins. See, e.g., M.-J. Azurmendi, E. Bacho \& F. Zabaleta, Reversing Language Shift: The Case of Basque, in Can Threatened Languages BE SAved? 234 (Joshua A. Fishman ed., 200I); B. Spolsky \& E. Shohamy, Hebrew After a Century of RLS Efforts, in Can Threatened Languages Be Saved? 350 (Joshua A. Fishman ed., 2001); M. Strubell, Catalan a Decade Later, in Can Threatened Languages Be SAved? 260 (Joshua A. Fishman ed., 200I). 
States, these intuitions have given rise to measures such as the Native American Languages Act, a federal law that promotes the preservation of native languages and cultures, many of which are in danger of disappearing. ${ }^{190}$ The autonomy regimes that have emerged around the world in various forms, ${ }^{191}$ along with human rights lawyers' defense of the principle of self-determination, ${ }^{192}$ also reflect an interest in providing weakened minority cultures with opportunities to flourish. Indeed, the defense of minorityrun institutions grows from a desire to see minority groups survive into the long term. ${ }^{193}$

But once we shift our focus from endangered language groups to the language diversity in multiethnic societies formed largely through immigration, the claim for long-term survival becomes difficult to defend on the grounds that the group might otherwise disappear. Unlike many national minorities, for whom failure to plan for long-term survival is tantamount to a cultural death sentence, migrants tend to be from cultures whose fortunes, for the most part, rise and fall independently of the immigrants' status in host societies. In other words, the assimilation of Mexican Americans presents no real threat to the survival of either Mexican culture or the Spanish language, though emigration to the United States may well change Mexican culture and politics in significant ways.

If the only remaining support for the survival claim is the cultural interests of individuals and groups, the survivalist impulse must remain ancillary to the protection of both individual and group autonomy. Such autonomy can only be fully realized if individuals and groups alike are permitted to evolve in response to changing social conditions, with the freedom to conclude that a particular language has lost its social viability or its ability to make the members of the group effective social actors. Absent the creation of ethnic enclaves surrounded by strictly enforced borders, dominant surrounding cultures will change culture-based groups. And, particularly for small national minorities, the benefits of knowing a widely spoken language that can connect that minority to the world are too great to justify prioritizmg cultural survivalism above all else. It may be that even the best-structured and responsive institutions "are at most able to contribute to the contemporary linguistic security of the language

190. The Native American Languages Act of 1990, Pub. L. No. 101-477, 104 Stat. 1152 (1990) (codified as amended at 25 U.S.C. $\S \S 2901-2906(2000)$ ).

191. See generally Henry J. Steiner, Ideals and Counter-Ideals in the Struggle Over Autonomy Regimes for Minorities, 66 NoTrE DAME L. REv. 1539 (1991).

192. See generally antonio Cassesse, Self-Determination of Peoples: A Legat REAPPRAISAL (1995).

193. See supra notes 34-58 (discussing legal reforms in Spain, Canada, and Latvia designed to ensure revival and survival of minority languages through establishment of public institutions run primarily, if not exclusively, in Catalan, French, and Latvian, respectively). 
community, rather than ensuring its long-run survival." ${ }^{194}$ But in offering a participatory approach to language diversity, my goal is not to ensure the long-term survival of every group. Instead, my aim is to make it possible for cultural minorities to engage in the public and social spheres without feeling coerced into abandoning the practices that structure their worldviews.

My emphasis on bilingualism as an aspiration, and its corresponding de-emphasis of particular groups' survival, thus resembles what Will Kymlicka has called a kind of American post-ethnic consensus. ${ }^{195}$ This view of ethnicity "favors voluntary affiliations[,] ... emphasizes the dynamic and changing character of many groups, and is responsive to the potential for creating new cultural combinations," ${ }^{196}$ but retains a primary focus on individual rights. But while the participatory conception I offer does recognize the fluidity of group identity, it diverges from the voluntary model in one important respect. My defense of a culture-based politics depends on the realization that culture and language are constitutive, which gives rise to the need for legal and institutional recognition of group interests through actual structural reform. The participatory aspiration is not to make it possible for people to pick and choose among available cultures in the public sphere. Rather, its purpose is to allow cultural minorities to live public lives with existing cultural affiliations intact, while recognizing that the endpoint of an integrated political community will always be a inoving target. In the process, the "mainstreain" either will be transformed or cease to exist. In other words, both the dominant culture and the cultural minorities within it will change through the process of participation.

194. MaCmillaN, supra note 59, at 19; see also Walzer, supra note 161 , at 152 ("State officials provide a framework within which groups can flourish but cannot guarantee their flourishing, or even their survival.").

195. See KYMLICKA, supra note 77, at 265, 266-67. As an example of this view, Kymlicka points to Canada's official policy of multiculturalism, adopted in 1971, and other immigrant-targeted multicultural policies that eoexist with cultural autonomy regimes for national minorities. See id. at 267. But while Kymlicka lauds the Act for eneouraging immigrants to treat their ethnocultural affiliations as voluntary, see $i d$, other eritics contend that the policy might ultimately be incoherent on the grounds that ethnic minorities cannot be integrated into mainstream public life without ultimately being assimilated. See Heath, supra note76.

196. See David Hollinger, Post-Ethnic America 3-4 (1995). Ronald Schmidt, an American theorist with multiculturalist sympathies, has articulated a view similar to the post-ethnic consensus, which he ealls "pluralistic integration." See ScHMIDT, supra note 117, at 221-50. He develops pluralistic integration as an alternative to assimilationist and confederationist approaehes, id. at 183220 - a goal 1 share. But he premises his approach on principles of justice and common good, whereas 1 emphasize recognition and participation. Incorporating non-English into the public sphere is not first and foremost about giving language minorities their "due," nor can it be about identifying some substantive vision of the common good-it is of neeessity too decentralized a project for sueh lofty aspirations. Moreover, a meaningful coneeption of language rights will be in some tension with integrationist attitudes and must inelude a willingness to accept non-English linguistic homogeneity or dominance under certain circumstances. 
In place of the conventional argument for linguistic survival, my participatory agenda provides a formula for dealing productively with multilingual social conditions while recognizing that the same interests in cultural transmission and control over cultural destiny are held by immigrants and national minorities alike. The most important question always will be how to manage the cultural concerns of extant generations in a manner that promotes social investment; for this reason, principles of freedom of association will be critical to shaping the agenda. Some groups, armed with this principle, and because of their sheer numbers, may well endure-Spanish-speakers in the United States seem a likely candidate, at least for the foreseeable future. Yet the source of the language rights defined in this Article is not the right to long-term survival, but rather the need to respect the choices of present-day actors, which may reach across generations, but not into perpetuity.

\section{Final Thoughts on Affection and Participation}

As I suggest above, the fear of coercion explains the tendency in American legal discourse to cabin culture in the private sphere, away from state involvement. This separation between public and private life is artificial, because cultural traits are complexly embedded in human personalities and are difficult to repress at the nebulous border between private and public spaces. The cultural affiliations that tie individuals and groups to one another will vary and may change over the course of individual lifetimes, or from one generation to the next. Consequently, rather than conclude that our public institutions should transcend culture, it would be more appropriate to adjust those institutions to respond flexibly to the peoplc's cultural demands. Because we are fundamentally culture-bearing people, promoting participation in a multiethnic society requires acknowledging the cultural dimension of citizenship.

A workable participatory model acknowledges that actual social engagement, perhaps the most critical of democratic habits, is more likely when personalized forms of affiliation are allowed room for expression. ${ }^{197}$ Ultimately, both individuals and communities are sufficiently flexible to sustain multiple ethnic and linguistic identities. Just as individuals have the capacity for bilingualism in their daily lives, so too can they draw on multiple affective affiliations, including multiple linguistic ones, to form coherent political personalities.

\section{The Structure of Language Rights}

Cultural recognition is not simply about symbolic affirmation of cultural interests. Cultural groups that seek recognition also desire political

197. See Rodriguez, supra note 22 , at 145. 
affirmation and pursue power as much as public validation of their cultures. A culturally conscious politics thus acknowledges the political legitimacy of groups of citizens who define themselves with reference to cultural characteristics. It thereby confers political status on the culturally defined group and the individuals who define their identities, at least in part, through membership in that group. ${ }^{198}$ The debate over how to structure this power-whether it should take shape through devolution, minority-run institutions, minority representation, or something less elaborateis always heated. But the final, important step in laying out the theoretical framework for a participatory approach to language difference is to specify the political and legal mechanisms through which the ideas expressed above should be realized. Whether we speak in terms of guaranteeing rights or protecting interests, and whether we think of the project as one for constitutional or statutory law, or even for informal norm development, it is important to clarify whether laws and policies should be addressed to groups or individuals.

Resistance to the idea of group rights is powerful in American legal culture. Many Americans dismiss language or cultural rights as archetypal group rights incompatible with American conceptions of rights, which are oriented toward the protection of the individual. ${ }^{199}$ The same concerns about coercion that explain the opposition to cultural recognition also support resistance to projects that appear to involve the protection of group rights.

But the group/individual dichotomy draws too crude a distinction. The language rights and policies I seek to develop are ultimately of a hybrid character. In this Section, to complement the conclusion reached abovethat the recognition of language groups promotes participation and social integration-I demonstrate that language rights, like most rights, can show regard for individuality by acknowledging that individual interests are einbedded in the interests of groups.

198. Charles Taylor traces the modern preoccupation with recognition in the form of "demands for the equal status of cultures and of genders" to the disintegration of social hierarchies, the corresponding irrelevance of honor as a social force, the increase in "individualized identity . . [ [that] arises ... [out of] being true to [one]self," and the "ideal of authenticity" that emerged in the eighteenth century. Taylor, supra note 152, at 27-28. According to Taylor, Hegel gave the concept of recognition its earliest treatment in Phenomenology of Spirit. Id. at 36.

199. The critique echoes the national minority versus immigrant dichotomy, which juxtaposes the culturally coherent group versus the individual seeking transformation. The former may have purchase on politics elsewhere in the world, but the latter represents a more American version of how to deal with cultural diversity. The rejection of the group rights construct stems from a belief that it treats individuals as members of groups, rather than as individuals. The construct also encourages individuals to identify with subgroups, at the expense of social cohesion. 


\section{Language Rights as Group Rights}

Language rights, as commonly understood, do not include the right to use any language, but instead focus on the protection of mother tongues. This emphasis on heritage thus connects the concept of language rights closely to group identity. As a result, it is not surprising that language rights often take shape as group rights, both in theory and in practice. ${ }^{200}$ What is more, people use and enjoy language in community, rather than in isolation. Respect for the linguistic interests of individuals, therefore, cannot be separated completely from the linguistic fate of groups and may require protecting groups as groups. Indeed, individuals accumulate power and develop important relationships through group affiliations. But there are many ways of protecting these intertwined interests, and the challenge is to give adequate recognition to both individual and group interests.

In their strongest form, group rights endow particular social units with power and perhaps even with sovereignty. The benefits of these arrangements may or may not trickle down to individual group members, and the individual's interests may be subordinated to the group's. The treatment of indigenous peoples in the United States and Canada roughly approximates this type of arrangement. ${ }^{201}$ The Belgian system, under which the country's three primary linguistic communities constitute rights- and duty-bearing units, reflects group rights in their strongest form, as well..$^{202}$ Each autonomous region governs in the majority language of the territory. Language rights attach to a culturally determined people, not to individual members of those communities. Individuals, therefore, do not take their rights with them when crossing regional boundaries, and the Belgian Constitution establishes that the boundaries, and hence the language rights, cannot be

200. A common and related question in language rights discourse is whether a multilingual society should implement a geographically based language rights regime or a portable, individual rights regime. See, e.g., Réaume, supra note 88 , at 271.

201. Section 35 of the Charter recognizes the "existing aboriginal and treaty rights of the aboriginal peoples of Canada." The Charter effectively treats First Nations People as sovereign, treatymaking entities. The Charter does inject a more individualistic element, however, by applying the rights to "male and female persons" equally. Part 1 of the Constitution Act, 1982, being Schedule B to the Canada Act 1982, ch. 11 (U.K.), $\S 35$ (Can.). This approach is subject to much debate in American Indian law. See, e.g., Santa Clara Pueblo v. Martinez, 436 U.S. 49 (1978) (rejecting, on tribal sovereign immunity grounds, equal protection challenge brought pursuant to Indian Civil Rights Act by Pueblo woman whose children had been denied tribal membership as result of her marriage to non-Pueblo and emphasizing that Congress intended to protect tribal self-determination when it passed Act).

202. See Wouter Pas, A Dynamic Federalism Built on Static Principles: The Case of Belgium, in Federalism, Subnational Constitutions, and Minority Rights 157, 158-59 (G. Alan Tarr, Robert F. Williams \& Josef Marko eds., 2004) ("[1]n 1970, the Belgian State was divided into four territorial linguistic regions: The Dutch-speaking region, the French-speaking region, the bilingual region of Brussels-Capital, and the German-speaking region. ... The authorities in each region may, in principle, only use the official language of that region in their dealings with citizens. In some municipalities, where a significant number of the inhabitants speak another language, special provisions were enacted to give individuals the right to continue to use their own language in their relations with the local authorities."). 
altered except through an elaborate series of procedures under which the three national groups hold specific voting and representation rights. ${ }^{203}$

Some theorists articulate a similarly strong version of group rights by calling for the devolution of political power to internal national groups. Kymlicka, in particular, contends that the creation of linguistically homogeneous, separate institutions for minority subgroups within a larger federal structure will foster the participation of minority groups in democracy by giving them the autonomy to control cultural policy. ${ }^{204} \mathrm{He}$ claims that, without separate institutions governed in their mother tongues, cultural minorities will lack the access to "societal culture" critical to true political autonomy. ${ }^{205}$ Quebec's language policies reflect this insight. ${ }^{206}$ Similarly, trends in human rights law toward the creation of "autonomy regimes"207 for cultural minorities assume that stability and democracy within nationstates depend on the creation of minority-run institutions capable of channeling the demands of culture-based political movements. ${ }^{208}$

Although territorial models and minority-run legal institutions have worked reasonably well in places such as Belgium, Spain, and Canada, the minority-run institution is hardly a panacea for diversity-related conflicts.

203. See Vernon Van Dyke, The Individual, the State, and Ethnic Communities in Political Theory, in The Rights of Minority Cultures 31, 40 (Will Kymlicka ed., 1995). The relevant Belgian constitutional provision reads:

The boundaries of the four regions may only be altered or amended by an act of Parliament passed on a majority vote in each linguistic group of each of the Houses, on condition that the majority of the members of each group are present and that the total votes in favour within the two linguistic groups attain two-thirds of the votes cast.

The Coordinated Constitution of the Kingdom of Belgium art. 4 (quoted in Van Dyke, supra, at 40).

204. KYMLICKA, supra note 77 , at 156.

205. Id.

206. Quebec's language laws and the support they receive from the Charter represent an effort to give French primacy in all aspects of public life. $C f$. Taylor, supra note 152, at 53-55 (diseussing the Charter's collective goals and efforts in Quebec to give French primacy, as well as the tensions that emerged between Quebec's language policy and the Charter's protection of individual rights).

207. Steiner, supra note 191. Steiner identifies three different types of autonomy regimes: (1) "power-sharing regimes" that allocate particular rights to ethnic populations, such as reserved cabinet positions or a certain number of representatives in the national legislature; (2) political control through devolution according to which ethnic minorities are permitted to govern their own affairs, such as in Catalonia; and (3) "personal law" regimes according to which ethnic minorities are allowed to govern themsclves according to their own laws, which are usually of religious origin. Id. at 1541-42.

208. The idea of devolution extends back at least as far as the multilateral minority rights treaties administered by the League of Nations after World War I. See U.N. Econ. \& Soc. Council [ECOSOC], Sub-Comm. on Prevention of Discrimination \& Prot. of Minorities, Study on the Rights of Persons Belonging to Ethnic, Religious and Linguistic Minorities, at 18-19, U.N. Doc. E/CN.4/Sub.2/384/Rev.1 (1977) (prepared by Francesco Capotorti). These treaties established rights for minorities to run their own institutions, obligated states to provide access to courts in the native language of linguistic minorities, and required adequatc facilities for primary school instruction in the minorities' language. Some scholars have contended that the demise of these treaties in the years leading up to World War Il engendered a deep suspicion of minority or group rights claims-a suspicion reflected in the heavy emphasis on individual rights in the human rights movement that flourished after World War II. See, e.g., Magnet, supra note 40, at 414-15. 
Devolution to minority-run institutions will not help secure rights for disparate ethnic groups spread out over a nation's territory, nor will it be ideal for richly diverse countries seeking a multicultural form of integration. ${ }^{209}$ Multiple linguistic communities sometimes exist within a national community defined by nonlinguistic factors, such as shared historical experiences or a common religion. A single linguistic identity may cut across particular national identities. As the presence of a sizable Anglophone population in Quebec suggests, no matter how decentralized a political system is, minorities always will be present within minorities. And, in a free society, they will be vocal. ${ }^{210}$ This minority-within-the-minority phenomenon is also characteristic of communities in the United States, where an English-speaking minority lives within a larger Spanish-speaking community, which is itself a minority within the larger national context. The existence of these overlapping language communities diminishes the practicality of the multiculturalist's preference for linguistically hoinogeneous, minority-run institutions. ${ }^{211}$ Nonetheless, in these same contexts, recognition of group identity and interests will be important. Finding an alternative to a strong form of group rights that still captures inescapably valid group interests thus becomes necessary.

\section{Language Rights as Hybrid Rights}

Even in systems that rely on minority-run institutions, various other means of addressing the concerns of disparate ethnic groups and the interests of individuals have been developed. Once again, the Canadian system offers a case in point, demonstrating that the interests of groups and individuals, while sometimes in competition, can be reconciled. ${ }^{212}$ On the one hand, the emphasis in Canadian case law on language rights as emanating from a historic compromise suggests a group-based conceptualization of

209. This latter model is one way of describing South Africa, which has opted to declare eleven languages official at the federal level. See lain Currie, Official Languages, in Constitutional Law of South AFrICA 37-2 (lain Curric ed., 1999).

210. See Clifford Krauss, Quebec Is Shedding Image as Hotbed of Political Rest, N.Y. TimEs, Apr. 3,2005 , at 16 .

211. Henry Steiner offers a related critique of autonomy regimes, pointing to what could be considered another danger of the push to linguistic homogeneity: "[A]utonomy schemes frustrate a major objective of the human rights movement of assuring that soeieties remain open to ehallenge and change.... To the extent that autonomy regimes protect historical differences but inhibit the creation ... of fresh differences, they would convert the human rights movement's framework of protection of open inquiry and advocaey into the protection of statie traditions." Steiner, supra note 191 , at 1552 .

212. The Charter of Rights is not strictly a list of individual rights. See Joseph Eliot Magnet, Multiculturalism in the Canadian Charter of Rights and Freedoms, in THE CANADIAN CHARTER OF Rights AND FreEdoms, at ch. 18, $\S 18-37$ (Gérald-A. Beaudoin \& Errol Mendes eds., 1996). Both the language rights provisions and the rights given to indigenous populations and sectarian schools represent group rights, thus reflecting the Charter's dual character. 
the issue. ${ }^{213}$ Although English speakers significantly outnumber French speakers in Canada as a whole, English and French have equal constitutional status within federal institutions. ${ }^{214}$ Securing equality between the two languages requires the maintenance of linguistic groups, which, in turn, requires compromises focused on group demands. These imperatives, for example, justify Quebec's insistence that immigrants to Quebec assimilate into the Francophone community, to help keep the Francophone population robust in the face of English language dominance in North America as a whole. Quebec's retention of control over language and cultural policy within the province promotes language equality in Canada generally, because the status of Francophones outside of Quebec depends in part on Quebec's vigorous promotion of the French language within its territory. The Canadian language rights regime thus assumes that preserving cultural autonomy requires considering whether the cultural practices that make that autonomy meaningful are at risk.

Yet language rights receive their higher-law expression in the Charter, which arguably subordinates collective goals to the rights of the individual. ${ }^{215}$ The Charter declares the equality of language groups but protects that equality by granting the individual the right to access federal institutions, public services, and education in one's mother tongue. ${ }^{216}$ These rights belong not just to Francophones in Quebec, but can be enforced by individual minorities in other provinces. Anglophones in Quebec also possess certain rights against the province, which ostensibly limit Quebec's ability to regulate language. ${ }^{217}$ The Charter ultimately protects individuals as members of groups, a structure that reflects the salience of group identity to the individual. Of course, if Canadian language protections were truly individual rights protections, they would extend to third-language speakers, and not merely Franco- and Anglophones. But this feature of the Canadian compromise does not obscure the possibility of hybridity.

In fact, individual rights guarantees that apply universally to all Canadians cabin some of the excesses of Canada's group-based arrangements. In Ballantyne v. Canada, Anglophone claimants challenged

213. See supra notes 53-56 and accompanying text (discussing historical origins of Canadian language rights regime).

214. Part I of the Constitution Act, 1982, being Schedule B to the Canada Act 1982, ch. 11 (U.K.), $\S I 6$ (Can.) (establishing that English and French have equal status).

215. Taylor, supra note 152, at 54-56 (discussing the tension between the Charter's individual rights framework and Quebec's demand for recognition as a distinct society).

216. Part I of the Constitution Act, 1982, being Schedule B to the Canada Act 1982, ch. 11 (U.K.), $\S \S 17-19,23$ (Can.).

217. As almost proof of this point, at the time of the Charter's passage in 1982, many in Quebec regarded this structure as a repudiation of the province's ability to run a democratic society in conjunction with an aggressive cultural policy. See Taylor, supra note 152, at 54-56 (stating that Anglophones are wary of Francophones' collective goals because Anglophones believe they impede individual rights and are inherently discriminatory) 
Quebec's Bill 178, which required the exclusive use of French for outdoor commercial signs and the names of commercial firms, arguing that the Bill violated their rights under various provisions of the International Covenant on Civil and Political Rights. ${ }^{218}$ The U.N. Human Rights Committee found in favor of the Anglophones, holding that the regulation violated article 19's guarantee of freedom of expression. ${ }^{219}$ The Committee found commercial communication was protected and concluded that restrictions on the speech rights of Anglophones were not necessary to protect the endangered status of Francophones in Quebec. ${ }^{220}$ Like the Supreme Court of Canada in Ford v. Quebec, the Committee concluded that less restrictive means could be used to protect the language interests of Francophones, such as requiring English commercial signs to include equivalent expressions in French. ${ }^{21}$ The Committee treated the parties' language interests as group-based concerns, reflecting on the relative status of Francophones and Anglophones in Canada as a whole. At the same time, it affirmed the Francophone minority's language law only insofar as it adhered to certain universally applicable free speech rights, which here benefited the provincial Anglophone minority. In other words, the Francophone majority retained its authority to regulate the province's linguistic landscape to the extent that its regulations did not needlessly disadvantage the minority citizens of Quebec.

These observations are not intended to demonstrate that the United States should adopt a Canadian-style system. Rather, they show that developing a conception of language rights need not entail entrenching group interests at the expense of individuals. In the final analysis, one would be hard-pressed to deny that individuals derive much of their identities from their collective affiliations. Respect for individual autonomy demands respect for the social and cultural groupings to which individuals belong. ${ }^{222}$

218. Ballantyne v. Canada, Communications Nos. 359/1989 and 385/1989, U.N. GAOR, Hum. Rts. Committee, 47th Sess., Annex at Iף 3.1-3.3, U.N. Doc. CCPR/C/47/D/359/1989 and 385/1989/Rev.1 (May 5, 1993), available at http://wwwl.umn.edu/humanrts/undocs/html/ v359385.htm. The U.N. Human Rights Committee rejected the claim that the Bill violated Article 26's equal treatment provision, as well as the claim that it violated Article 27. Id. 1 111.2, 11.5. The Committee reasoned that, because Article 27 applied to states and not subunits such as provinces, Anglophones could not invoke its protection because they were not minorities within the state of Canada. Id. 111.2 .

219. Id. ๆ 11.3-11.4.

220. Id. $\$ 11.3$.

221. Id. I 11.4. For a detailed discussion of this case, see William Green, Schools, Signs, and Separation: Quebec Anglophones, Canadian Constitutional Politics, and International Language Rights, 27 DENV. J. INT'L L. \& POL'Y 449, 462-67 (1999).

222. As scholars of human rights law have observed, the "thrust of [Article 27 of the ICCPR] is to stress culture as a communal, group phenomenon." Steiner, supra note 191, at 1547. Steiner argues that groups transmit culture from one generation to the next and preserve cultural and social differences in a society. Hence we see "the link between autonomy regimes and an ideal of maintaining diversity." Id. at 1549 . This cmphasis "permeates human rights law," id. at 1548, and "commit[s] the human rights 
Language rights guarantees, like those adopted in Canada, respect individual rights in the context of group-based interests, demonstrating that the legal recognition of groups is not in irresolvable tension with respecting individual integrity.

As I explain in more detail in Part III, the American legal system possesses resources for expressing this kind of developed appreciation for group interests. The possibility of hybridity is already reflected in American antidiscrimination law. Individuals enforce civil rights claims as members of classes of similarly situated people, and the law protects them from discrimination based on their memberships in particular groups. In other words, the law recognizes racial, ethnic, and gendered groups as salient social entities and, by extension, offers remedies to individuals in acknowledgment of their group memberships. ${ }^{223}$ Going forward, principles of freedom of association and personal autonomy can ground a framework that relies on group identity to promote participation. Despite the limited appeal of strong forms of group rights in the United States, then, it is nonetheless possible to deal in terms of individual affiliation with group identities. Though this emphasis suggests that groups matter only because "they are essential for the well-being of the individual,"224 we can still acknowledge that "[g]roup interests cannot be reduced to individual interests," and that groups experience prosperity and decline, and can be harmed by societal actions. $^{225}$

Even territorial solutions short of devolution that emanate from states and localities will be feasible in parts of the United States and will contribute to efforts to acknowledge the interests of groups. ${ }^{226}$ The decision of the New Mexico Supreme Court to require the state judicial system to

movement to the protection of people's ongoing capacity to form, develop, and preserve different types of groups," id.

223. As Habermas puts it, "in the political arena those who encounter one another are collective actors contending about collective goals and the distribution of collective goods. Only in the courtroom and in legal discourse are rights asserted and defended as actionable individual rights ..." Habermas, supra note 150 , at 108 .

224. Kukathas, supra note 101 , at 233 (noting that to the extent that liberal theory countenances existence of groups, it is because such groups are linked to the well-being of individuals). Charles Taylor contends that "profound philosophical assumptions" based on Kantian notions of human dignity and rationality underlie this conception of morality and agency as lodged in the individual. Taylor, supra note 152, at 57 . In my view, even if we can justify group rights based on the preeminence of the political value of equality, it is hard to imagine a moral justification for doing so that is stronger than the equal worth of all individuals.

225. Margalit \& Raz, supra note 104, at 87. Margalit and Raz, in acknowledging the independent identity of groups nonetheless declare that the moral importance of the group's interest depends on its value to the individual. Id.

226. The 1999 decision of the border town of El Cenizo, Texas, which is populated overwhelmingly by Spanish speakers, to conduct all of its public affairs in Spanish exemplifies this kind of localized language solution. See, e.g., Hillary Durgin, Will El Cenizo's Present Be America's Mañana?, Fin. TıMEs, Sept. 4, 1999, at 5; Thaddeus Herrick, Spanish Official Language in "SafeHaven" Border City, Hous. Chron., Aug. 14, 1999, at A1. 
accommodate jurors who do not speak English reflects a kind of territorial solution that strives to protect the rights of individuals engaged in the public sphere. ${ }^{227}$ The court's decision both protected the rights of non-English speakers to serve on juries and reinforced the state's more general interest in promoting the status of non-English-speaking language groups. ${ }^{228}$ While such an interpretation of the rights associated with political participation might not be generalizable to other parts of the country, and thus not cognizable as universal, portable rights, this event in New Mexico offers a clear example of "Our Federalism" at work. ${ }^{229}$ A framework that incorporates culture into the public sphere in order to protect the individual's ability to associate freely, within the communities of one's choice, reflects the ultimate, hybrid expression of freedom. As I demonstrate in the next Part, encouraging participation in the institutions of social life requires harmonizing the interests of groups and individuals, which in turn depends on openness to multilingualism.

\section{III}

\section{Language and Participation In the United States}

Articulating a set of participatory practices for all democratic societies is beyond the scope of this Article. Because language law and policy must reflect specific institutional and national contexts both, any such generalizations will be limited in their accuracy and utility. I offer the United States as a case study, however, to develop the idea of multilingual participation through examples, and to demonstrate that American legal culture contains resources to support a theory of language rights. The federalist structure of our Constitution, designed in part to encourage experimentation in governance, is helpful in managing the diversity that may seem unwieldy at the national level. Furthermore, our culture of constitutional rights and selfgovernment also contains ample resources and vocabulary to facilitate the cultural dimensions of politics. Principles of freedom of association, parental autonomy, and freedom of conscience all can be understood as having cultural components.

In the discussion that follows, I consider several of the most common sites and forms of language conflict in the United States: the political campaign, the English-only law, the English-only workplace rule, and the debate over language education. I consider how lawmakers and members of the public can manage language difference in each context to maximal

227. The court delivered its opinion from the bench. For discussion of the opinion, see Elizabeth Amon, Breaking a Language Bar in N.M., NAT'L L.J., Feb. 7, 2000, at A13. See also Marilyn Haddrill, The Language of Justice: NM Ruling Allowing Non-English-Speaking Jurors Draws Notice, DaLLAS MoRning NEws, Mar. 8, 2000, at 21 A.

228. See Amon, supra note 227.

229. See Younger v. Harris, 401 U.S. 37, 43-45 (1971) (explaining the doctrine of "Our Federalism" as "poliey against federal court interference with state court proceedings"). 
participatory effect. 1 draw on tools available at all levels of organization: federal, state, local, and civil society. Although different legal and political resources exist to channel participatory objectives in each case, 1 converge in each case on multilingual rather than monolingual presumptions.

But before turning to specifics, it is important to note that developing strategies to meet the participatory goals outlined in Part 11 requires two perspectives on the language question: a rights perspective and a policy one. As the Canadian case suggests, a rights-based framework will be a crucial component of promoting participation in a multilingual setting, because the rights and participation frameworks reinforce one another. On the one hand, language rights work as the engines of participation: protecting certain individual rights promotes personal autonomy, which powers the social engagement that a healthy democracy requires. Actual participation in social decision making, particularly over matters of deeply personal concern, heightens individuals' sense of control over their place in society and therefore makes them more confident and better social actors. On the other hand, by participating in important social institutions, individuals honor the personal integrity whose protection is at the core of rights-based theory.

Rights-based thinking alone, however, will not be sufficient, as many of the interests at stake in the language debate will not be best articulated in the form of rights. We must also think in terms of policy. Language-related discourse and the rules that emerge from that discourse, such as English-only laws, have important symbolic or expressive effects, because they emit cultural signals about general attitudes toward linguistic difference and language minorities. In addition, and perhaps more importantly, when thinking about how to structure certain institutions, language should be thought of as a value. Consequently, linguistic interests will compete with other social values for primacy and resources, and such interests might be advanced in different ways for different groups depending on their preferences.

\section{A. The Symbolic Politics of Language Use}

Understanding the value of recognizing language minorities through symbolic politics is the first step in crafting a participatory strategy. By symbolic politics, I mean the use of cultural symbols, such as language, in political discourse to signal solidarity with or appreciation of certain minority groups. Symbolic politics are important, particularly in multiethnic democracies, because "symbols that make national identities feel secure" anchor the notion that peaceful coexistence among groups is possible. ${ }^{230}$

230. Magnet, supra note 40 , at $427-28$. 
Indeed, the multiculturalist insight into the "ritualistic," language-specific component of political communication ${ }^{231}$ underscores the danger of calling for a single public language in a society of complex, overlapping linguistic sub-units. A heavy preference for monolingualism will limit the forms of political expression available to a citizenry and risk alienating nondominant segments of society from politics.

The 2002 Democratic primary in the Texas gubernatorial race offers a poignant example of how largely symbolic uses of languages other than English confer recognition and therefore encourage loyalty to the body politic. The two candidates, both Mexican American, elected to hold an entirely Spanish-language debate - the first event of its kind in Texas politics. ${ }^{232}$ The need to communicate with monolingual Spanish speakers did not motivate the decision, as most Texan voters who speak Spanish also speak English. Rather, the recognition that a Spanish-language debate would have a unique ritualistic resonance with a largely bilingual audience mobilized the politicians. Similarly, the GOP's recent efforts to fund Spanish-language instruction for its candidates, as well as the everexpanding efforts of politicians on both sides of the aisle to incorporate Spanish into their stump speeches, reflect an awareness of the salience of non-English, even for English speakers. ${ }^{233}$

Symbolic uses of language are compelling because they include characteristics traditionally reserved for private life in public discourse. ${ }^{234}$ This kind of symbolic politics enables people to assert ownership over some aspect of public life and is thus based on the same assumption that supports practices such as bilingual legislative enactment in officially bilingnal societies. ${ }^{235}$ Behind the Canadian prescription that all laws must be enacted in both French and English rests a belief that the people should see themselves as the authors of their laws and the owners of their

231. KYMLICKA, supra note 77, at 213.

232. See Merccdes Olivera, Will Latinos' Gains Matter in November?, Dallas Morning News, Mar. 16, 2002, at 30A (noting that the "primary elections were historic for many reasons ... . [1]t was the first time eandidates for Texas governor ... debated in Spanish on television"); R.G. Ratcliffe, Morales Bid Still Effective Minus Funds, Hous. CHRON., Mar. 7, 2002, at A17 (noting that the debate "made history as the nation's first televised debate in Spanish between major candidates").

233. William E. Gibson, President Stops at Miami Catholic Church to Surprise and Applause of Parishioners, Sun-SEntinel, Nov. 1, 2004, at 1A ("Bush delivered his well-practiced stump speech ... adding a few words of Spanish”); Gary Martin, Pollsters: Big Race Remains Heated, SAN ANTONio ExPRESS News, Oct. 2, 2004, at 11 B ("Both campaigns have spent the year targeting the emerging Latino political force with Spanish language advertising and stump speechcs that include cute and catchy phrases in Español [sic].").

234. This recent move by the GOP is ripe for a cynical interpretation: Republicans would rather appeal to an ethnic nostalgia to win Latino votes than address issues of particular concern to Latinos. But even if this is the casc, the attempt still reflects an awareness of the political dimensions of language difference. And detractors should be careful about emphasizing too vehemently a critique that assumes Latino voters are superficial.

235. See Silver, supra note 53, at 693 (discussing underrepresentation of Francophones in the public service). 
government. ${ }^{236}$ In this vein, at least one American state has adopted an English-plus resolution that gives quasi-official status and symbolic recognition to a language other than English. ${ }^{237}$ While such recognition remains largely symbolic, it challenges the monolingual version of American identity behind the typical English-only measure. These resolutions also mark the multilingual heritage of a community and suggest the possibility of state accommodation of languages other than English in response to demographic evolution.

Of course, despite the value of symbolic politics, for cultural recognition to bring people into the political community successfully, it must traffic in more than ritual and image. The measures adopted in Canada to address the language question suggest that something more powerful than symbolism motivates efforts to manipulate the visage linguistique. ${ }^{238}$ Behind the desire to insert linguistic symbols into public life lies a concern not just for status, but also for control. ${ }^{239}$ Symbolic statements purporting to recognize a group's legitimacy, even if constitutional in nature, do little to facilitate interaction among different linguistic groups. Nor will most symbolic statements, on their own, broaden the public sphere to include the members of the linguistic group so recognized. As a result, the participatory account requires that we assess whether the linguistic rules that actually govern mid-level social institutions improve or reduce the quality and breadth of the people's participation in those institutions.

\section{B. Official English Laws and Self-Government}

To understand how to make the transition from symbolic uses of language to truly participatory language policies, it is helpful to consider the English-only laws that were a flashpoint of the language wars of the 1990s and that remain a persistent, though less frequently discussed, phenomenon today. ${ }^{240}$ Such laws have been assessed traditionally in antisubordination or

236. See id.

237. See, e.g., Resolution of the New Mexico Legislature (Mar. 1989), reprinted in BIL.L Piatt, Only English? Law and Language Policy in the United States 25 (1990).

238. This term is invoked to describe Quebec's attempts to regulate the language of commercial signs and firm names.

239. See MACMILLAN, supra note 59, at 113 (quoting Conseil de la Langue Francaise, an advisory body that urged the premier to reinstitute French-only requirement to protect visage linguistique).

240. At least twenty-two states had official English laws on the books in 2005. See Peter W. Schroth, Language and Law, 46 AM. J. CoMP. L. 17, 17-18 (1998) ("[I]n recent years over twenty of the fifty states have fclt their English-speaking ethnicity sufficiently threatened to require statutes or state constitutional provisions declaring English their official language...."). The exact count of official English laws depends on the type of statute counted as an official language enactment. South Dakota, for example, has passed a statute declaring English the "common language." S.D. CodiFIED LAws $\S 1-27-20$ (1995). Under Hawaii law, both English and Hawaiian are official languages. See Haw. Rev. Stat. Ann. § 1-13 (LexisNexis 2005). 
status-based terms. ${ }^{241}$ The scholarly concern has been that English-only laws push the limits of the Equal Protection Clause by establishing an ethnicity-based classification without a legitimate state purpose. ${ }^{242}$ But although such statutes have symbolically exclusionary implications, it is notoriously difficult to demonstrate that they reflect animus against minorities, rather than a more benign intent to affirm the obvious dominance of English. ${ }^{243}$ Indeed, whether such laws have actual subordinating effects is unclear.

Under my participatory framework, I would not categorize an English-only law as presumptively invalid. Instead, I would evaluate the law based on how it affects the relationship between the people and the state. Under this framework, courts would scrutinize the limitations such laws place on the ability of the individual to both comprehend and structure her relationship with the state. This type of inquiry embodies an important participatory interest; whether one thinks the state-participant relationship should be involved or minimal, it remains central in a participatory democracy. The accessibility and credibility of public institutions shapes a person's willingness to engage with the public sphere. In fact, in recognition of its importance, state courts have safeguarded the state-participant relationship using the free-speech principles of their state constitutions, ${ }^{244}$ and the federal courts have protected it by articulating general access-togovernment rights based on the requirements of due process. ${ }^{245}$

241. See, e.g., Yxta Maya Murray, The Latino-American Crisis of Citizenship, 31 U.C. DAvIS L. REv. 503, 582-89 (1998) (noting the standard equal protection approach to assessing English-only laws and offering a First Amendment alternative on the ground that the use of Spanish is political, solidaristic speech and that the suppression of Spanish reflects an assumption that it is an inferior language); Juan F. Perea, Demography and Distrust: An Essay on American Languages, Cultural Pluralism, and Official English, 77 MINN. L. REv. 269, 356-71 (1992) (developing the equal protection argument).

242. For a discussion of these sorts of claims, see generally Rodriguez, supra note 22, at 161-72.

243. See generally Murray, supra note 241 (discussing courts' rejection of constitutional claims against official English laws).

244. See infra notes $246-49$ (discussing Oklahoma and Alaska free speech cases).

245. See, e.g., Tennessee v. Lane, 541 U.S. 509 (2004) (holding that, as it applies to cases implicating the right of aecess to the courts, Title 11 of the Americans with Disabilities Act constitutes a valid exercise of Congressional authority under section 5 of the Fourteenth Amendment); see also id. at 523 (detailing different types of access rights, including access to courts, procedural due process rights, right to trial by jury, and right of access to criminal proceedings); Bounds v. Smith, 430 U.S. 817,822 (1977) (requiring that access to courts be "adequate, effective, and meaningful"); Ex parte Hull, 312 U.S. 546, 549 (1941) (striking down prison regulation prohibiting prisoners from filing habeas corpus petitions unless state official determines them to be "properly drawn"); Chambers v. Baltimore \& Ohio R.R., 207 U.S. 142, 148 (1907) ("The right to sue and defend in the courts is the alternative of force. In an organized society it is the right conservative of all other rights, and lies at the foundation of orderly government. It is one of the highest and most essential privileges of citizenship ...."); Harbury $v$. Deutsch, 233 F.3d 596, 607 (D.C. Cir. 2000) (finding that government cover-ups can infringe upon right of access to courts); Layton v. Elder, 143 F.3d 469, 472-73 (8th Cir. 1998) (holding that the county must "make each county service, program, and activity, when viewed in its entirety, readily accessible and usable by individuals with disabilities"). 
In a 2002 decision, the Supreme Court of Oklahoma relied on this type of access-to-government principle to strike down an official English law. ${ }^{246}$ The court held that an initiative petition declaring English the official language violated the state constitution's free-speech provision. ${ }^{247}$ In so doing, the Court emphasized the importance of freedom of speech "in the political context," articulating a broad conception of that context:

[p]rotection of [political] freedoms is an essential part of the right to participate in self-government. Information and meaningful discussion are necessary for a self-governing society. There should be no potential interference with a meaningful dialogue of ideas concerning self-government; nor should there be a threat of liability that causes self-censorship. ${ }^{248}$

According to the court, the English-only law, which barred the state's public institutions from using languages other than English, impeded individuals' access to information and resources necessary for self-government. ${ }^{249}$ Because the purpose of the freedom of speech, under this view, is to promote self-government, the protection of speech requires protecting the means through which individuals communicate with the state. The interests of state speakers, as well as of the listening public, require safeguarding not only the freedom to say what one wants, but also the manner in which ones says it. ${ }^{250}$

Though based on compelling principles, the court's conclusion contains a serious analytical flaw. The court found a free-speech violation, but it did not impose an obligation on the state to provide information and services in languages other than English to the public. But if such services are not constitutionally required, and the state chooses not to provide them, does that not mean that the threat to self-government posed by linguistic inaccessibility is inescapable? Reliance on free-speech principles, which are not typically understood to impose affirmative obligations on states, to asscss English-only laws, is therefore a limited strategy-at least pragmatically, if not conceptually. The most that this approach can accomplish is to preserve a space for administrative officials to exercise discretion in

\footnotetext{
246. In re Initiative Petition No. 366, 46 P.3d 123 (Okla. 2002).

247. Id.

248. Id. at $\mathrm{I} 27$ (internal eitations omitted).

249. See id. A state court in Alaska struck down an English-only law for similar free speeeh reasons, citing the violation of the rights of citizens to receive information and ideas. Kritz v. Alaska, No. 3DI-99-I2 CI (Alaska Super. Ct. Mar. 1, 1999), available at http://www.alaskabar.org/ opinions/69.html (declaring unlawful an initiative that stated " $[t]$ he English language is the language to be used by all public agencies in all government functions and actions").

250. In Yñiguez v. Arizonans for Official English, 69 F.3d 920 (9th Cir. 1995), vacated sub nom. Arizonans for Official English v. Arizona, 520 U.S. 43 (1996), the Ninth Circuit relied on the First Amendment to invalidate Arizona's highly restrictive English-only law. While the court based its holding on the free speech rights of public employees, the court also expressed concern for the speech rights of the receiving public. $I d$. at 932 .
} 
addressing the linguistic needs of the population, or to preserve the ability of lawmakers to craft formal and informal arrangements to accommodate different linguistic needs.

Given these limitations, then, a court faced with a challenge to an English-only law only can ask certain types of questions to determine whether the law hinders self-government. Does the rule affect service delivery? Are the kinds of services affected integral or peripheral to fulfilling the bargain between the people and the state? Does the law prohibit municipalities from operating in a non-English language, even when those municipalities have determined that their operations would be more effective were such services to be provided? Not all English-only laws are equally restrictive; some simply declare English to be part of the state's heritage ${ }^{251}$ whereas others prohibit any government official from ever uttering a word in a language other than English. ${ }^{252}$ Applying the selfgovernment framework, laws in the former category are likely to remain on the books, while laws in the latter category will face greater scrutiny. In states or localities with small linguistic minority populations, even laws in the latter category might have de minimis participatory effects, rendering them potentially permissible. Ultimately, by understanding English-only laws through the participatory lens, rather than discrediting them as manifestations of inequality, we begin to address the actual problem with the statutes-the possibility that they will interfere with the participant-state relationship, making government inaccessible to linguistic minorities.

\section{English-Only Rules and the Workplace}

The rise of the English-only workplace rule has eclipsed in significance the debate over official language laws, at least for the time being. The controversy surrounds rules established by employers prohibiting the speaking of non-English languages in the workplace. ${ }^{253}$ The rules have appeared in a variety of workplaces, and they take different forms, sometimes requiring employees to speak English during certain times of day and, in other instances, permitting only English to be spoken at all. In January 2002, for example, the chief administrator of the Paterson, New Jersey, courthouse attempted to prohibit all courthouse employees from using

25I. See, e.g., IOWA CODE $\$ 1.18$ (2004) (declaring that "[t]hroughout the history of Iowa and of the United States, the common thread binding individuals of differing backgrounds together has been the English language," and providing that many official acts must be in English, but also stating that government officials may use languages other than English).

252. See, e.g., ARIz. ConST. ART. XXVIII, § 3 ("This State ... shall act in English and in no other language.").

253. See, e.g., Jim Fitzgerald, Foreign-Born Doughnut Shop Manager Issues English-Only Edict, Assoc. Press, Mar. I8, 2005, at 1 (describing English-only rule adopted by Dunkin' Donuts manager in Yonkers, New York). http://www.nysun.com/article/10773. 
languages other than English. ${ }^{254}$ Emphasizing the city's effort to "have bilingualism in every department," the city's mayor quickly declared that the judge had no such authority, ${ }^{255}$ underscoring the incompatibility of such workplace rules with the objectives of public workplaces serving multilingual populations. In the private sector, these rules affect both blue-collar workers in the service sector and white-collar and professional workers in settings such as hospitals. ${ }^{256}$ Some states have passed statutes prohibiting workplace language restrictions absent an overriding business necessity ${ }^{257}$ and thereby have accomplished through state regulation what federal civil rights litigation has struggled to deter.

This practice appears to have emerged in the early 1980 s, and complaints lodged with the EEOC quintupled from 1996 to $2000{ }^{258}$ National origin-related complaints, which often include challenges to English-only rules, represent one of the fastest growing sources of complaints to the Commission. ${ }^{259}$ And the dramatic immigration to this country, highlighted in Part I, promises to fuel the proliferation of English-only regulations in public and private workplaces.

Although I explore the participatory consequences of English-only workplace rules elsewhere, ${ }^{260}$ a detour into the Title VII litigation on this question will help explain the emerging participatory need for limitations on such rules. ${ }^{261}$ Whereas many complaints over English-only workplace rules have settled, a number of them have reached the federal courts as cases alleging disparate impact on the basis of national origin. ${ }^{262}$ The courts

254. See Robert Hanley, Judge's English-Only Directive Rescinded by Paterson Mayor, N.Y. TiMEs, Jan. 18, 2002, at B5.

255. Id.

256. See Cristina M. Rodriguez, Language Diversity in the Workplace, 104 NW. U. L. REV. (forthcoming 2006) (discussing the different contexts in which such rules have arisen).

257. See, e.g., CAL. Gov'T CoDE $\$ 12951$ (Deering 2005) (codifying California Fair Employment and Housing Commission regulations, which prohibit workplace language restrictions unless "[t]he language restriction is justified by a business necessity" and "[ $t]$ he employer has notified its employees of the circumstances and the time when the language restriction is required to be observed and of the consequences for violating the language restriction").

258. See, e.g., Carlos R. Soltero \& Keith Strama, English-Only Rules in the Workplace in Texas, 64 TEx. J. BUs. L. 130, 131 (2001) (noting the increasing commonality of English-only workplace rules in Texas); Shim, supra note 66 (noting the increase in complaints to the EEOC about the existence of English-only rules in the workplaee, and attributing the rise to a number of factors, including EEOC outreach to employees and employers).

259. See Colorado Casino to Pay \$1.5 Million to Settle EEOC National Origin Bias Case, DAILY LABOR, July 21,2003 , at A-10 (noting that charges of national origin discrimination increased by $28 \%$ from 1995 to 2002 ).

260. See generally Rodríguez, supra note 256.

261. I have explored the participatory consequence of these rules more fully elsewhere. Id. (analyzing the various types of English-only rules, assessing the EEOC's national enforcement strategy against these rules, and proposing an alternative to Title VII litigation as a means of regulating the practice).

262. See, e.g., Garcia v. Spun Steak, 13 F.3d 296 (9th Cir. 1993) (upholding English-only policy); Garcia v. Gloor, 618 F.2d 264 (5th Cir. 1980) (same); Kania v. Archdioceses of Philadelphia, 14 F. 
tend to dismiss these suits on the ground that no prima facie case of national origin discrimination can be established by bilingual plaintiffs based on the mere existence of an English-only rule. ${ }^{263}$

In reaching this conclusion, however, the courts seem to contemplate the possibility that such rules, if imposed on employees who do not speak English at all, have a cognizable impact. Of course, the bilingual persons affected by such rules are nearly as likely to be disproportionately national origin minorities as the affected non-English-speaking employees. The only explanation for the difference in the courts' approach is that they understand the nature of the impact in each case to be distinct. In the case of workers unable to speak English, some courts seem to fear the possibility that English-only rules might isolate them socially by silencing them, or leaving them unable to communicate at all. This fear reflects a conception of the workplace as a social setting where communication plays an important role in connecting the individual to his environment. ${ }^{264}$ BilinguaIs, however, remain able to communicate in the face of an English-only rule; in the courts' view, their ability to comply with the rule amounts to the capacity to engage in self-help, and the effects of the rules on bilinguals are therefore de minimus. ${ }^{265}$

Without question, the impact of an English-only rule on the bilingual worker is less severe than the impact on the non-English speaker. But the difference is ultimately one of degree, not of kind. The impact on both types of speakers is a participatory one. English-only rules limit the capacity of linguistic minorities to be a full part of and form relationships in a very basic social institution. The rules disrupt associative dynamics in the workplace, and they create a rift between the workplace and the community in which the workpIace is situated. By forcing minority languages out of public spaces, such rules also make it potentially more difficult for minority communities to sustain their native languages - the essential glue that keeps individuals at various stages of assimilation connected to one another. In other words, these rules interfere not just with employees' expressive interests, or their interests in displaying individuality through certain behaviors, but also with their associative interests, or their interests in interacting with others, both in and out of the workplace. These associative interests should be protected primarily because the workplace functions not

Supp. 2d 730 (1998) (dismissing Title VII disparate impact claim on ground that no impact arose but permitting retaliation claim to go forward); see also Long v. First Union Corp. of Virginia, 894 F. Supp. 933 (E.D. Va. 1995) (holding that employees failed to establish prima facic case of disparate impact under Title VII).

263. See supra note 262 .

264. See, e.g., id. at I488 ("[N]on-English spcakers cannot enjoy the privilege of conversing on the job if conversation is limitcd to a language they cannot speak."); see also 29 C.F.R. $\$ 1606.7$ (a) (EEOC guideline establishing that English-only rulc may "create an atmosphere of inferiority, isolation, and intimidation").

265. See, e.g., Garcia v. Spun Steak, 998 F.2d 1480, 1487 (9th Cir. 1993). 
only as a commercial setting, but also as a social institution-an intuition buttressed by a growing literature portraying the workplace as a site where significant social bonds take shape. ${ }^{266}$

By challenging the validity of these rules, I do not mean to suggest that employers never can justify imposing them on their employees. Non-English speakers may well use language to isolate and harass fellow workers unable to comprehend them, and such harassment certainly has participatory consequences. Choosing a blanket prohibition instead of a more targeted disciplinary rule, however, allows employers to overreach. Indced, the linguistic and conversational complexity of many workplaces, where multiple conversations among shifting groups of people occur simultaneously, undermines the claim that English-only rules will always make the workplace more collegial. Whether the rules promote collegiality depends, in part, on the composition of the workplace, the community from which the employer draws its workforce, and the community the employer serves. Increased scrutiny of English-only rules may make it more difficult for employers to police the workplace, and they may place employees who do not understand non-English at an occasional disadvantage vis-à-vis their coworkers. But given the multilingual nature of our population, most individuals will experience this cost. Moreover, these consequences reflect the costs of pursuing an objective outlined in Part II: spreading the burden of integrating minorities and immigrants across the population by expecting English speakers to tolerate some discoinfort in their environments. This objective is a participatory one, not just because it more effectively integrates minority workers into social institutions such as the workplace, but also because it imposes an appropriate social responsibility on the population as a whole to confront and absorb the diversity generated by immigration. Some states, such as California and Illinois, have gone so far as to pass laws prohibiting English-only rules in the workplace. ${ }^{267}$ These laws recognize that such rules not only interfere with the right to work, but also threaten to isolate employees. ${ }^{268}$ Such laws, ultimately, derive their regulatory force from a participatory conception of the workplace.

266. See, e.g., EstLUND, supra note 119 , at 7 ("The workplace is the singlc most important site of cooperative interaction and sociability among adult citizens outside the family.").

267. See Cal. Gov't Code $\S 12951$ (Deering 2005); 775 Ill. Comp. Stat. 5/2-102 (2005). A similar bill, establishing that an employer "commits an unlawful employment practice if the employer requires an employee who is bilingual or multilingual to speak only English while at the workplace," has been introduced in the Texas legislature but has not become law. See H.B. 3379, 2003 Leg., 78th Sess. (Tex. 2003).

268. Cf. Matkov Salzman, New Illinois Law Declares Blanket "English-Only" Work Rules Unlawful Discrimination, in EMP. L. UPDATE I (Jan. 2004). 


\section{Language Education and Two-Way Integration}

No account of multilingualism and participation would be complete without extended treatment of the most explosive issue in this country's language debates-bilingual education. In many societies with multilingual populations, public education rests at the heart of the language question. ${ }^{269}$ Minority language education represents the chief survival mechanism for a language, because in the educational context, a language's fate is sealed. For some multilingual societies, such as Canada, this realization has generated constitutionally protected minority educational rights. ${ }^{270}$ But in the United States, the only language-based educational "right" that exists is the statutory right of non-English-speaking students to programs that assist them in overcoming language barriers, or the right to learn English. ${ }^{271}$

Nonetheless, the sprawling debate over bilingual education in the United States presents a particularly useful lens through which to examine language and participation. After all, the public schools bear the chief responsibility for cultivating individuals capable of participating in society, and they represent the social institutions of most immediate and local interest, not just to parents, but to all those concerned with society's future. Language education also represents a matter of some urgency for school districts. Current immigration patterns are bringing "unprecedented diversity in cultural backgrounds and languages" into the classroom, ${ }^{272}$ not only in states that traditionally have had high numbers of immigrant children in their schools, but also increasingly in urban, rural, and suburban schools across the country. ${ }^{273}$ The bilingual education debate ultimately forces us to confront the question of whether it ever makes participatory sense for the state to promote bilingualism, or the persistence of minority languages.

The answer to this question is complex. On the one hand, a participatory approach to language education demands acceptance of Englishlanguage acquisition as a means of promoting advancement and integration for all children. On the other hand, the participatory approach also demands that we reorient the framework through which we debate language education policy. We should understand what states have lost by banning the use of native language instruction for limited English proficient

269. See, e.g., Pierre Foucher, Language Rights and Education, in LaNGUAGE Rights IN CANADA 258 (Michel Bastarache ed., 1987).

270. Part I of thc Constitution Act, 1982, being Schedule B to the Canada Act 1982, ch. 11 (U.K.), $\S 23$ (Can.).

271. See, e.g., Lau v. Nichols, 414 U.S. 563 (1974)

272. Marcelo Suárez-Orozco, Peter D. Roos \& Carola Suárez-Orozco, Cultural, Educational, and Legal Perspectives on Immigration: Implications for School Reform, in LAW AND SCHOoL Reform: Six Strategies for Promoting Educational Equity 162 (Jay P. Heubert cd., 1999).

273. See $i d$. at $162-63$ (noting a defining characteristic of immigration today: for a variety of familial and economic reasons, immigrants are moving from traditional gateway cities and states to communities less accustomed to coping with linguistic and cultural diversity). 
students (LEPs). And we should understand what states have gained through educational reforms that promise bilingual education for native and non-native speakers of English.

Though the bilingual education debate in the United States involves these two dimensions-English-language acquisition and native language maintenance-the law only emphasizes one of them-the acquisition of English. In Lau v. Nichols, ${ }^{274}$ the Supreme Court held that the San Francisco public schools violated their obligations under Title VI of the Civil Rights Act of 1964 by failing to provide programs for LEP students of Chinese ancestry to assist them in learning English. The essential premise of Lau-that all students must have adequate access to English-language instruction-is sound under the participatory formulation. ${ }^{275}$ Access to the dominant medium of communication is a basic prerequisite for effective and meaningful participation, a conclusion consistent with the overriding bilingual ethos of my participatory account.

But in the decades since Lau, courts, commentators, and administrative agency officials have battled over whether fulfilling these obligations requires bilingual education that includes native-language instruction, or whether English immersion classes are sufficient. ${ }^{276}$ With one outlying and dated exception, no court has held that Title VI requires bilingual education specifically. ${ }^{277}$ But it was not until recently that states began prohibiting schools from using LEP students' native languages in teaching them English and other subjects. ${ }^{278}$ While such native language bans, passed through popular referenda in California, Arizona, and Massachusetts, do not

274. Lau, 414 U.S. at 566.

275. Id. at 565 (noting that "those who do not understand English are certain to find their classroom experiences wholly incomprehensible and in no way meaningful"); $i d$. at 568 ("Where inability to speak and understand the English language excludes national origin-minority group children from effective participation in the educational program offered by a school district, the district must take affirmative steps to rectify the language deficiency in order to open its instructional program to these students.") (internal citations omitted).

276. For a detailed discussion of the case law and statutes through which the debate can be traced, see Rodríguez, supra note 22, at 209-16. For important reference points in this debate, see Equal Educational Opportunity Act, 20 U.S.C. $\$ \S 1701-1720,1703(f)(1994)$ (providing that "no state shall deny equal educational opportunity to an individual . . by ... the failure . . . to take appropriate action to overcome language barriers that impede equal participation by its students in its instructional programs" but not requiring bilingual education); Guadalupe Org., Inc. v. Tempe Elementary Sch. Dist. No. 3, 587 F.2d 1022, 1029 (9th Cir. 1978) (holding that Lau did not require schools to provide LEP students with a bilingual-bicultural education; rather, schools need only take affirmative steps to rectify language deficiencies); Valeria G. v. Wilson, 12 F. Supp. 2d 1007 (N.D. Cal. 1998) (rejecting constitutional challenge to California initiative hanning use of native language in instruction of LEP students).

277. United States v. Texas, 506 F. Supp. 405 (E.D. Tex. 1981) (imposing bilingual education as remedy in school desegregation suit).

278. See ARIZ. REV. STAT. $\$ 15-752$ (LexisNexis 2005) ("[A]ll children in Arizona public schools shall be taught English by being taught in English..."); CAL. Educ. CODE $\S 305$ (Deering 2005) ("[A]ll children in California public schools shall be taught English by being taught in English."); Mass. ANN. Laws ch. 71A, $\$ 4$ (LexisNexis 2005) (same). 
necessarily impede LEPs' acquisition of English, ${ }^{279}$ they do hamper LEPs' retention of their native languages. ${ }^{280}$ Legal discussions rarely address retention, or the impact of English-language instruction on the mother tongue. Courts consistently assume that retention is irrelevant to the rights of the children, who will be served best by being given access to the American mainstream. ${ }^{281}$ But this blindness to retention undermines important constitutional interests of parents and children and ignores the potential participatory value of native language instruction and retention. I address these two consequences in turn.

To understand how the elision of native language affects rights central to democracy, we must first focus on the nature of language education. Language instruction transmits an important tool and a culture resource from an authority figure to a child. ${ }^{282}$ Parents, by virtue of being parents, have a profound interest in cultural transmission; children share this interest, because it facilitates their relationships with their parents and communities. And this interest-in intimate, familial association-is at the core of the so-called concept of ordered liberty protected by the Due Process Clause of the Fourteenth Amendment. ${ }^{283}$

Given the nature of the transmission at stake, then, both existing law and liberal theory support protecting parents' decision making authority in the area of language instruction. Indeed, it is precisely in the educational context that our analysis must account for the individual's liberty interest in controlling his or her cultural destiny. To be sure, it may seem as if the

279. For a discussion of the mixed social science data on this point, see, e.g., WaYne P. Thomas \& Virginia P. Collier, A National Study of School Effectiveness for Language Minority STUdENTs' LONG-TERM ACADEMIC ACHIEvement (2003), http://www.crede.ucsc.edu/research/ llaa/1.1_final.html (concluding, inter alia, that English language learners immersed in the English mainstream because their parents refused services showed large decreases in reading and math achievement by fifth grade).

280. Laura Alamillo \& Celia Viramontes, Reflections from the Classroom: Teacher Perspectives on the Implementation of Proposition 227, 24 Bilingual Res. J. 1, 12 (2006), available at http://brj.asu.edu/v2414/pdf/ar11.pdf (noting that after the implementation of this ban, "teachers have witnessed an overall negative effect on second language learners' cultural and linguistic identity")

281. See, e.g., Valeria G., 12 F. Supp. $2 \mathrm{~d}$ at 1014-15 (rejecting equal protection challenge to California's Proposition 227, which banned bilingual education, and noting that language debate is about "which system will... enable [children] to function as American citizens and enjoy the opportunities and privileges of life in the United States").

282. Simon H. Cheng \& Wen H. Kuo, Family Socialization of Ethnic ldentity Among ChineseAmerican Pre-Adolescents, 31 J. OF COMP. FAM. STUD. 463, 464 (2000) ("Through teaching family languages and ethnic cultures, immigrant children learn to identify with their parents' nationalities and thus develop an ethnic consciousness distinct from mainstream society."); Bernhard Nauck, Intercultural Contact and Intergenerational Transmission in Immigrant Families, $32 \mathrm{~J}$. OF CRoss Cult. Psych. 159, 168 (2001) (“'L]anguage retention [by an immigrant child of her parents' language] increases its direct effect on the child's ethnic identification.").

283. See, e.g., Meyer v. Nebraska, 262 U.S. 390 (1923) (holding that a Nebraska law prohibiting teaching of any modern language other than English violates Fourteenth Amendment liberty interests, including pupils' rights to acquire knowledge, parents' power to control their children's education, and language teachers' liberty). 
child's interest has been lost in this formulation. But children remain largely powerless whether the parent or the state makes decisions for them. And given that this particular debate focuses on public schools, and not on parents' rights to remove their children from public schools altogether, the English language acquisition right already recognized by the law satisfies the child's interest in integration into a world beyond his or her family. ${ }^{284}$

But the question remains: would this analysis have a legal/doctrinal upshot? State referenda banning native language instruction affect only public schools, where states have a certain amount of authority to regulate and constrain parental choices. As noted above, with one exception, courts have never constitutionally required bilingual or bicultural education; ${ }^{285}$ constitutional resources do not extend far enough to require bilingual education or to differentiate between the groups who might be entitled to it. Further, courts have proven ill-equipped to police the types of decisions that must be made in creating language education programs. Such decisions hinge on the demographic characteristics of the school district in question, the availability of competent teachers, and the programmatic demands on a resource pie of surely limited size. Finally, as an empirical matter, some parents actually prefer English immersion to bilingual education programs, ${ }^{286}$ which, in many cities, have been hothouses for educational failure because of the lack of adequate resources to support quality programs. $^{287}$

284. The child, of course, also has an interest in quality language instruction. If English immersion were a more effective means of teaching English, then arguably the child's interest would be best served by English immersion programs, since the teaching of English to LEP students is a critical participatory objective. In fact, it is difficult to make claims of this kind. Despite the claims of its political critics, bilingual education generally has not been an abject failure. Considerable research supports the conclusion that students in properly designed bilingual programs consistently outperform peers in English-only classrooms. The research most critical of bilingual education suggests that it is slightly less effective than structural immersion programs, but also indicates that more research is needed to substantiate this claim. See Stephen D. Krashen, Condemned Without a Trial: Bogus Arguments Against Bilingual Education 49-51 (1999). More specifically, in the first few years after Californians passed Proposition 227, LEP students' test scores did go up, but the improvement occurred among students in bilingual classrooms, as well as students in English-only classrooms. See Patricia Gándara, Learning English in California: Guideposts for the Nation, in Latinos: RemaKING America 339, 349-50 (Marcelo M. Suárez-Orozco \& Mariela M. Páez eds., 2002).

285. See, e.g., United States v. Texas, 506 F. Supp. 405 (E.D. Tex. 1981) (ordering comprehensive bilingual education program to comply with Lau and Equal Educational Opportunity Act).

286. Compare James Traub, The Bilingual Barrier, N.Y. TIMES, Jan. 31, 1999, § 6, at 32 ("A recent poll by Public Agenda, a non-partisan research organization, found that 75 percent of recent immigrants oppose bilingual instruction. Very few immigrants care about multiculturalism or bilingualism; they want their children to learn English as fast as possible in order to make it into the American mainstream, where good jobs are available ....") with Mireya Navarro, For Parents, One Size Doesn't Fit All In Bilingual Education, Feb. 24, 2001, N.Y. TimEs, § B, at 1 ("Some groups of parents, like the emigrés from the former Soviet Union, seem overwhelmingly to reject bilingual education, while staunch supporters can be found among other groups-parents from Haiti and the Dominican Republic, for example.").

287. See, e.g., Suárez-Orozco, Roos \& Suárez-Orozco, supra note 272, at $189-90$ (observing that language programs often disserve LEP students not because of inherent problems with programs, but 
In light of these constraints, the liberty interest in control over cultural transmission will serve, at most, to defend against state encroachment on family life. Applying the principles articulated above, states could be prohibited from banning altogether the use of the native language in language education, which would leave decisions about complementary native language instruction in the hands of parents and local school boards. The underlying rationale would be that banning native language use is not an ordinary policy decision, but one that conflicts with constitutionally protected parental choice rights. ${ }^{288}$ This approach also would reinforce choice among policymakers, leaving them free, along with parents, to experiment with different forms of English immersion and native language use. ${ }^{289}$ That this approach offers a fair solution to the language education debate is underscored by the fact that states like Massachusetts have made efforts to interpret native language bans as not covering bilingual programs for nonLEP students. ${ }^{290}$ By understanding bilingual referenda to affect a basic liberty interest, we accord parents of LEP students the same power over language education given other parents in the same context.

Restraining states in this way also would have important ancillary social benefits. First, parental control promotes social, democratic interests, because it helps preserve existing frameworks for managing pluralism. ${ }^{291}$

because of "inept, passive-aggressive, or outright hostile administration"); see also H.D. ADAMSON, Language Minority Students in American Schools 231-32 (2005) ("Research shows that wellrun $B E$ programs are effective. Research also shows that some $B E$ programs are not as effective as they should be... [S]ome programs have trained teachers, good materials, and community support, but others don't. Conclusions about the effectiveness of a BE program can only be generalized to other programs that have similar resources and students."); Jacques Steinberg, City's Bilingual Education Debated at Spirited Hearing, N.Y. TImes, Oct. 18, 2000, $\S$ B, at 4 ("Even staunch advocates of the city's bilingual system conceded ... that it was riddled with problems, as evidenced by the fact that one of every two students enrolled in such classes is still enrolled after three years, and often after eight years, even though such programs are intended to be transitional.").

288. In California, the referendum banning bilingual education contained an exception permitting parents to seek waivers from the English-only requirement. Waivers were permitted under one of three conditions: if the child already knew English; if the child was over ten and the school believed another approach might better suit his or her needs; or if the school staff determined that the student had special needs that would be better addressed in another program. See Gándara, supra note 284, at 344.

289. See, e.g., Peter Schuck, Diversity in America: Keeping Government at a Safe DISTANCE 122-23 (2003) (proposing that parents be given vouchers to choose among different types of language instruction in order to provide "broader parental information and choice, services tailored more closely to individual need," as well as "greater accountability by providers.").

290. The Massachusetts legislature overrode Governor Romney's efforts to apply the referendum to two-way bilingual education programs. See Raphael Lewis \& Michelle Kurtz, Legislature Loosens Law on English Immersion, BostoN GloBe, July 15, 2003, at A1; Jonathan Saltzman, Reinstating Two-Way Bilingual Ed Is Hailed, Boston GloBe, July 20, 2003, § Globe West, at 1 (quoting Governor Romney declaring legislature's actions a "demonstration of unfathomable arrogance" and describing two-way bilingual programs preserved in Massachusetts)

291. Martha Minow, About Women, About Culture: About Them, About Us, Daedalus, Fall 2000, at 125,139 . Minow concludes that the existence of a system where parents have most of the responsibility for and control over the upbringing of their children "establishes a framework of pluralism and avoids state standardization of children." Id. at 139. Further, such a system keeps many 
As Martha Minow has pointed out, "[p]arental autonomy, along with religious free exercise, is the chief instrument of cultural pluralism in this country."292 Like the free exercise protection afforded by the First Amendment, parental control reinforces the status of the individual as the ultimate decision maker in certain matters of personal and community concern. Furthermore, parental control also operates as a decentralized check on the state's authority by empowering individuals to make decisions that reflect their own values. This is a power essential to the maintenance of a robust democracy in a pluralistic society.

Second, native language bans make it difficult, if not impossible, to take advantage of the bridging capacity of bilinguals. If law restrains policymakers from ensuring native language retention alongside English acquisition, then the bilingual resources needed to bridge the gaps between different linguistic communities never will be developed to their full capacity. Relatedly, native language bans interfere with policymakers' ability to experiment with different types of language education. Such bans are wholly inconsistent with the experimental form of democratic participation I emphasize in Part II, because they remove a key piece of the policy puzzle through a top-down, uniform solution masquerading as a populist reform effort. In the education context, in particular, experimentalists emphasize that successful reforms have been based on "solutions lying between top-down standards and bottom-up school-based reform,"293 and that responsive and sound educational policy depends on the involvement of parents, civil society groups, and governmental actors alike. ${ }^{294}$ And experts on the education of LEPs stress that the complexity of these students' concerns demands collaboration among community advocates, parents, educators, and researchers. ${ }^{295}$ Native language bans thwart this dynamic process.

In emphasizing the importance of experimentation in this area, my claim is not that native language instruction should always be employed. Rather, my point is that something as central to education as the student's native language represents an indispensable input in the policy-making process. Under existing constitutional structures as understood by the courts, we have no good legal mechanism through which to articulate and resist interference with policy collaboration-a factor that gives the

decisions that affect children private, "avoiding both public controversies and public responsibility about everything from what constitutes appropriate moral instruction to what for children are decent standards of living, medical services, and time with loving adults." Id.

292. Id.

293. See Liebman \& Sabel, supra note 116, at 191; see also Suárez-Orozco, Roos \& SuárezOrozco, supra note 272 , at 179 (referencing studies concluding that relational aspects of schooling mean that top-down reforms cannot address concerns central to educating LEPs).

294. See generally Liebman \& Sabel, supra note 116 , at 191.

295. See Suárez-Orozco, Roos \& Suárez-Orozco, supra note 272, at 164. 
rights-based approach a strategic salience for now. A rethinking of standard ideas of federalism and decentralization along the lines suggested by democratic experimentalists may point in a new and productive direction. ${ }^{296}$ For the time being, we can begin with the policy observation that the trend toward native language bans in the education of linguistic minority children disrupts crucial participatory objectives. Freeing local schools and parents from the constraints imposed by the bans would open up important democratic space, in the sense that it would permit the parties directly involved in the educational relationship to respond with maximum flexibility to the needs and concerns of parents and children.

To be sure, emphasizing the experimental possibilities that would be restored by a rolling back of the native language bans necessarily tempers claims made on behalf of parental control, because the collaborative process requires both flexibility on the part of interested parties as well as involvement by bureaucracies of one kind or another. What is more, immigrant parents, in particular, will have difficulty becoming meaningful partners in school reform without some form of external financial and logistical support. A number of clear obstacles stand in the way of their participation: inability to speak English, lack of familiarity with the American educational system, inability to vote and status as outsiders to local politics, and economic disadvantage. ${ }^{297}$ And even once we recognize parents' liberty-based rights to control the law's reach, they must still fight over the resources needed to act on that right. A second-generation set of questions asking who will be entitled to what resources to create which programs will inevitably follow a constitutional assessment of a native language ban. ${ }^{298}$ But acknowledging that parents have an interest of constitutional dimension at stake is not inconsistent with the conclusion that decisions about the types of programs to adopt in a given district must involve decision makers other than parents. Nor is it inconsistent with the conclusion that devising viable language education programs is better left to the policy realm than to constitutional litigation.

When left free to experiment, there is evidence that school districts, together with parents and researchers, have devised creative innovations on traditional bilingual education programs. The new trend toward two-way bilingual education, or prograins designed to help native English speakers

296. See supra notes $116 \& 120$ (discussing Sabel's conception of decentralized experimentation). 297. See Suárez-Orozco, Roos \& Suárez-Orozco, supra note 272, at 195-97.

298. Limiting principles will have to govern resource allocation. Contrary to the claims of theorists who reject the rights-based paradigm for the framing of culture-based interests, a language or cultural right need not create an absolutist entitlement that imposes an inflexible mandate on the state. Cf. Richard Thompson Ford, Cultural Rights and Civic Virtue (Fondazione Eni Enrico Mattei, Working Paper No. 99.2003), available at http://papers.ssm.com/sol3/papers.cfm?abstract_id=478483. Apart from framing the constitutional dimension of language rights as primarily defensive, as 1 have done, statutorily created rights in the delivery of either public education or public services can be cabined by limiting principles. 
and non-native English speakers learn one another's languages, exemplifies the participatory benefits of decisions that embraee bilingualism in individuals and multilingualism in society. Miami-Dade County public schools, for example, have used a federal grant aimed at improving the services provided to LEP students to embark on an ambitious language curriculum. ${ }^{299}$ The school district has complemented traditional English as a Second Language (ESL) classes with a wide variety of language programs that benefit all language learners, including native English speakers. These programs offer Spanish for Spanish speakers, elementary Spanish as a second language, and district-wide initiatives designed to ensure that all children are exposed to two languages in a sixty percent English instruction, forty percent other language instruction format. ${ }^{300}$ The purpose of these programs "is to produce students who can communicate orally and in writing in English and in another language with proficiency commensurate with their...educational level [and] age.... and who can interact effectively with groups using those languages." 301 With this objective, the Miami-Dade schools are taking steps to harness language diversity as a participation-promoting value. Such programs integrate non-English speaking students while enabling them to sustain preexisting linguistic ties to family and community. At the same time, they give monolingual English speakers heightened access to a linguistic subcommunity in their midst. In addition to the documented benefits to scholastic achievement, ${ }^{302}$ these programs represent deliberate attempts to restructure a public sphere to adapts to society's changing cultural characteristics.

\section{E. Final Thoughts on the American Case}

In exploring the most important arenas of language conflict in the United States, 1 have demonstrated how embracing bilingualism in individuals and multilingualism in society would encourage broad participation in public and social life. The language debate in the United States revolves most publicly around symbol and rhetoric - a tendency exemplified in attempts by politicians to use Spanish to their electoral advantage, as well as

299. See Miami-Dade County Public Schools, Bilingual Education and World Languages, http://bilingual.dadeschools.net/BEWL/programs.asp (last visited Jan. 6, 2006) (describing two-way bilingual education programs of Dade County Schools); see also ADAmson, supra note 287, at 209-10 (describing Coral Way Elementary program).

300. David R. Schwandt \& Timothy J. Tobin, Inst. for Educ. Policy Stud., Report on Title VII, Subpart I: Professional Development Activities, Miami-Dade County Public ScHoOLs (1999), http://www.ncela.gwu.edu/pubs/reports/profdev/.

301. See id.

302. See THOMAS \& COLLIER, supra note 279, http://www.crede.org/research/llaa/1.1_es.html ("Native-English speakers in two-way bilingual immersion programs maintained their English, added a seeond language to their knowlcdge base, and achieved well above the 50th percentile in all subject areas on norm-refcrenced tests in English. These bilingually schooled students equaled or outperformed their comparison groups being schooled monolingually, cn all measures."). 
in the official English movement. But, more importantly, the debate rests at the heart of everyday interactions in our most important social institutions--the workplace and the public schools. It unfolds through the daily attempts by workers, managers, school officials, and parents to deal with the linguistic consequences of an ever-expanding, non-English-speaking population.

Once we set our goal as the promotion of participation, rather than the articulation of a coherent conception of national identity, it becomes clear that active promotion of bilingualism best serves our ends. In politics, the participatory conception means acknowledging the salient identities present in the body politic. In government, ensuring accessibility and promoting self-government mean developing the linguistic capacities of individuals and institutions and require leaving institutions with the discretion to respond to the linguistic particularities of the communities they serve. And, in the schools where socialization occurs and the workplaces where we live out our adult lives, our aim should be to expand the individual's associative options. Particularly in the schools context, the participatory objective depends on thinking in terms of adding to individual students' linguistic capacities and expanding their options for association, rather than in terms of replacing an old identity with a new one. These objectives will require acceptance of a certain amount of cacophony. But as this American case study underscores, emphasizing linguistic commonality as a prerequisite for participation dramatically oversimplifies the nature of interaction among individuals, among communities, and between communities and institutions in a large and deeply diverse society like the United States in 2006.

\section{CONCLUSION}

At the heart of this Article rests a concern for autonomy-for the ability of individuals to control their cultural destinies. All language rights debates implicitly assume that the cultural dimension of identity formation and social interaction cannot be escaped. Indeed, in recognizing the cultural dimension of citizenship, language must be central, not just because of its comprehensive character, but because it is the medium through which all choices must be made. The purpose of this Article has been to explore a new way of framing these debates within the framework of liberal democracy. While the remediation of historical injustices, designed to promote language-group revival, will be necessary to the realization of democracy in many contexts, a multiethnic democracy should ultimately develop a participatory agenda suited to the linguistic dynamics that define its people. Although language rights have value as a mechanism for addressing the concerns of voeal national minorities, they have proven attractive precisely because language functions as a repository of our expressive capacities. 
Language rights should therefore be designed to incorporate the interests of all cultural groups, regardless of their historical positions. While the argument for participation is not a claim for equal status among all languages or a call to abandon limiting principles that wisely reflect certain historical imperatives, it is an attempt to orient the discussion of language policy toward the future.

In the final analysis, the state cannot be neutral with respect to language use. But the participatory ethic does not require neutrality. It only requires accepting certain limitations on the paradigm of single-language dominance, or acknowledging that the sociological primacy of the dominant language does not, by definition, make a monolingual public sphere prcferable to a multilingual one. Under the participatory formulation, we would understand the monolingual bias in countries like the United States not as a reflection of fear of or animus toward minorities, but as a failure of political imagination - as a rejection of the fundamentally democratic belief in the value of heterogeneity. 
